\title{
Raumzeitliche Dynamik der Parameter des Energie-, Wasser- und Spurengashaushalts nach Kleinkahlschlag
}

\author{
Daniel Fröhlich
}

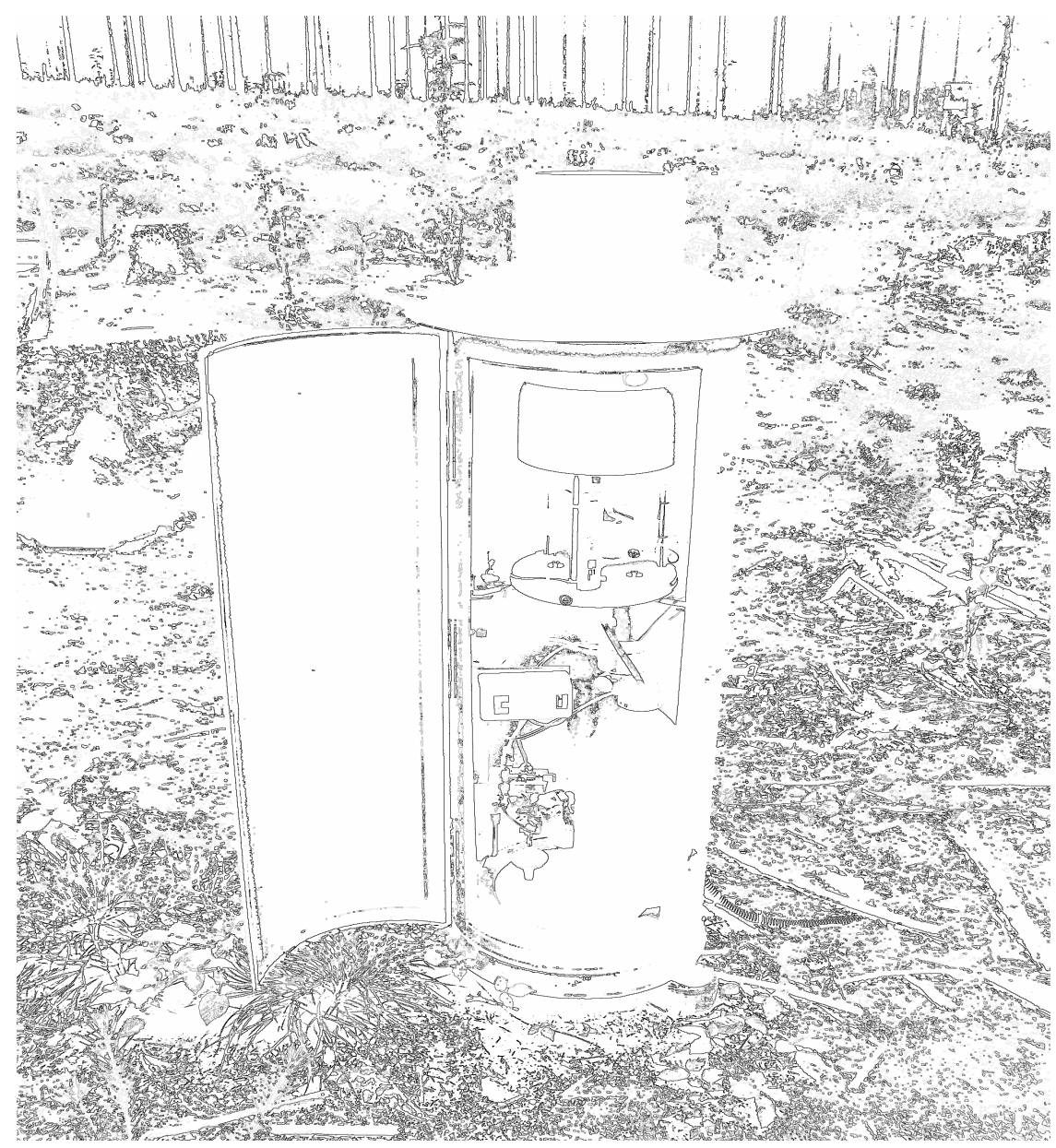



Raumzeitliche Dynamik der Parameter des Energie-, Wasser- und Spurengashaushalts nach Kleinkahlschlag

\author{
Dissertation \\ zur Erlangung des Doktorgrades \\ der Fakultät für Forstwissenschaften und Waldökologie \\ der Georg-August Universität Göttingen
}

Vorgelegt von

Daniel Fröhlich

Geboren in Nürnberg

Göttingen, Januar 2009 
1. Gutachter:

Prof. Dr. Beese

2. Gutachter:

Prof. Dr. Hölscher

Tag der mündlichen Prüfung:

5. Juni 2009 


\section{Abbildungsverzeichnis}

Abbildung 1-1: Blockbild des Wirkungsgefüges auf einem Kahlschlag und dem Bestand ................ 3 -

Abbildung 1-2: Organisation und Zusammenarbeit mit Trägern verbundener Teilprojekte ............... - 4 -

Abbildung 1-3: Die Kahlschlagfläche Otterbach im Solling im 2. Jahr nach der Hiebmaßnahme mit dem Wechsel von beschattetem zu besonnten bereich.

Abbildung 1-4: Die Kahlschlagfläche Otterbach im Solling im 4. Jahr nach der Hiebmaßnahme mit starker Entwicklung von Pionierpflanzen.

Figure 2-1: $\quad$ Soil temperatures and their standard deviations before harvesting in 2002 (above) and after harvesting in 2004 (bottom), divided in control plot, selected harvesting plot and clear cut plot.

Figure 2-2: $\quad \mathrm{N}_{2} \mathrm{O}-\mathrm{N}$ emission and standard deviations before harvesting in 2002 (above) and after harvesting in 2004 (bottom) divided in control plot, selected harvesting plot and clear cut plot (for each plot $n=10$ ).

Figure 2-3: $\quad \mathrm{CH}_{4}-\mathrm{C}$ emissions and standard deviations before harvesting in 2002 (above) and after harvesting in 2004 (bottom) divided in control plot, selected harvesting plot and clear cut plot (for each plot $n=10$ ).

Figure 3-1: $\quad$ Plan of measurement design of the clear cut investigation field at Otterbach site.... - 34 -

Figure 3-2: $\quad$ Graphical example for the calculation of transition zones by a function fitted to soil temperatures of the forest interior, the clear cut and the edge. The transition zone within this example would completely lay within the forested area on the left site.

Figure 3-3: $\quad$ Local (points) and interpolated (lines) energy inputs in July in Mega Joule along four transects of different aspects from forest interior to clear cut centre. The forest interior is represented at the left hand side of the tree.

Figure 3-4: $\quad$ Pattern of energy input at the cleared area and the surrounding stand at Otterbach site (Solling, Germany) and the boarders of transition zones for averaged topsoil temperatures in May.....

Figure 3-5: $\quad$ Pattern of energy input at the cleared area and surrounding stand at Otterbach site (Solling, Germany) and the transition zones of averaged topsoil temperatures in July.

Figure 3-6: $\quad$ Pattern of energy input at the cleared area and surrounding stand at Otterbach site (Solling, Germany) and the transition zones of averaged topsoil temperatures in September....

Abbildung 4-1: Plan der Messanordnung des Kahlschlags Otterbach im Solling.

Abbildung 4-2: Benetzungskapazität des Altbestandes. Durch Anpassung nach Formel 4-1 wurde die Benetzungskapazität durch eine parallele Verschiebung zur 1:1-Linie gewonnen (unterbrochene Linien).

Abbildung 4-3: Benetzungskapazität des Bestandsrands. Durch Anpassung nach Formel 4-1 wurde die Benetzungskapazität am nordwestlichen Bestandsrand (B) durch eine parallele Verschiebung zur 1:1-Linie gewonnen (unterbrochene Linien).

Abbildung 4-4: Eindringwiderstände des Bodens auf der Versuchsfläche Otterbach im Solling inn Mega Pascal. Dargestellt sind die Eindringwiderstände und ihre Standardabweichungen $(n=8)$ um die Stationen im Bestand $(A)$ sowie am Nordwestrand (B) und auf dem Kahlschlag (D).

Abbildung 4-5: Bodenmatrixpotentiale in $20 \mathrm{~cm}$ Tiefe im Altbestand der Versuchsfläche Otterbach. Dargestellt sind die Modellergebnisse für den gesamten Untersuchungszeitraum und die Messwerte für den Kalibrierungszeitraum 1.1.2006-31.8.2006.

Abbildung 4-6: Bodenmatrixpotentiale in $60 \mathrm{~cm}$ Tiefe im Altbestand der Versuchsfläche Otterbach. Dargestellt sind die Modellergebnisse für den gesamten Untersuchungszeitraum und die Messwerte für den Kalibrierungszeitraum 1.1.2006-31.8.2006. 
Abbildung 4-7: Bodenmatrixpotentiale in $20 \mathrm{~cm}$ Tiefe am Bestandesrand. Dargestellt sind die Ergebnisse der Simulationen I und II sowie der Messungen bis $800 \mathrm{hPa}$ (Messbereich der Tensiometer) für den Kalibrierungszeitraum 1.1.200631.8.2006 am Nordwestrand (B). Für Simulation I wurden die Strahlungsverhältnisse de Bestandesinneren herangezogen, während für Simulation II ein höherer Strahlungsinput implementiert wurde, der den lateralen Effekten Rechnung trägt.

Abbildung 4-8: Bodenmatrixpotentiale in $60 \mathrm{~cm}$ Tiefe am Bestandesrand. Dargestellt sind die Ergebnisse der Simulationen I und II sowie der Messungen für den Kalibrierungszeitraum 1.1.2006-31.8.2006 am Nordwestrand (B). Für Simulation I wurden die Strahlungsverhältnisse de Bestandesinneren herangezogen, während für Simulation II ein höherer Strahlungsinput implementiert wurde, der den lateralen Effekten Rechnung trägt.

Abbildung 4-9: Bodenmatrixpotentiale in $20 \mathrm{~cm}$ Tiefe im Kahlschlagzentrum (C). Dargestellt sind die Modellergebnisse und die Messwerte für den Kalibrierungszeitraum 1.1.200631.8.2006.

Abbildung 4-10:Bodenmatrixpotentiale in $60 \mathrm{~cm}$ Tiefe im Kahlschlagzentrum (C). Dargestellt sind die Modellergebnisse und die Messwerte für den Kalibrierungszeitraum 1.1.200631.8.2006.

Abbildung 4-11:Bodenmatrixpotentiale in $20 \mathrm{~cm}$ Tiefe am Südwestrand des Kahschlags (D). Dargestellt sind die Ergebnisse der Simulationen III und IV sowie die Messwerte für den Kalibrierungszeitraum 1.1.2006-31.8.2006. Simulation III wurde mit Strahlungswerten des Kahlschlagzentrums durchgeführt, während ein reduziertet Strahlungsinput der Simulation IV den lateralen Einfluss des umgebenden Bestands berücksichtig.

Abbildung 4-12:Bodenmatrixpotentiale in $60 \mathrm{~cm}$ Tiefe am Südwestrand des Kahlschlags (D). Dargestellt sind die Ergebnisse der Simulationen III und IV sowie die Messwerte für den Kalibrierungszeitraum 1.1.2006-31.8.2006. Simulation III wurde mit Strahlungswerten des Kahlschlagzentrums durchgeführt, während ein reduziertet Strahlungsinput der Simulation IV den lateralen Einfluss des umgebenden Bestands berücksichtig.

Figure 5-1: $\quad$ Results of $\mathrm{ECH}_{2} \mathrm{O}$ measurements with different mixtures of granular material and water.

Figure 5-2: Signal of an $\mathrm{ECH}_{2} \mathrm{O}$ probe between glass stacks of different height (same below and above the probe). Points are measurements; the line is an interpolating spline function.

Figure 5-3: Effect of a gap between $\mathrm{ECH}_{2} \mathrm{O}$ probe and two lime-sand-stone bricks. Indicated is the average gap on each side of the probe. Points represent repeated insertions of the probe. Lines connect means.

Figure 5-4: $\quad$ Comparison between water retention curves derived from laboratory (desorption curve, dashed line) and from field data (solid line) for $20 \mathrm{~cm}$ (left) and $60 \mathrm{~cm}$ depth (right).

Figure 5-5: Development of the snowpack water equivalent (solid line), the soil water content and soil water tension in 20 and $60 \mathrm{~cm}$ depth during snowmelt in March 2006 under closed canopy

Figure 5-6: Development of the snowpack water equivalent (solid line), the soil water content and soil water tension in 20 and $60 \mathrm{~cm}$ mineral soil during snowmelt in March 2006 at the cleared site.

Figure 5-7: Development of precipitation (top), the soil water content (middle) and soil water tension (bottom) in 20 and $60 \mathrm{~cm}$ mineral soil during summer storm in August 2006 under closed canopy.

Figure 5-8: Development of precipitation (top), the soil water content (middle) and soil water tension (bottom) in 20 and $60 \mathrm{~cm}$ mineral soil during summer storm in August 2006 at the cleared site. 


\section{Tabellenverzeichnis}

Table 2-1: $\quad$ Precipitation and air temperature at Solling weather station (Silberborn) on a long term basis and for years of investigation on an annual basis and for growing season

Table 2-2: Texture and soil chemical properties in $0-5 \mathrm{~cm}$ mineral soil depth at the investigated plots $(n=5)$ before harvesting......

Table 2-3: $\quad$ Mean soil temperatures $\left({ }^{\circ} \mathrm{C}, \mathrm{n}=10\right.$ ) and water filled pore space (WFPS $\%, n=7$ in 2002 and $\mathrm{n}=16$ in 2004) at $5 \mathrm{~cm}$ mineral soil depth for the periods June to November at the years 2002 and 2004

Table 2-4: $\quad$ Mean values of extractable ammonium, nitrate, and total $\mathrm{N}$ contents $\left(\mathrm{mg} \mathrm{kg}^{-1}\right.$, $\mathrm{n}=27$ ) and standard deviations (sd) in $0-10 \mathrm{~cm}$ mineral soil depth in growing season 2004.

Table 2-5: $\quad \mathrm{N}_{2} \mathrm{O}$ emissions $\left(\mathrm{mg} \mathrm{N} \mathrm{m}^{-2}\right.$ ) for a 158 days period for treatments at Otterbach between 21st June and 26th November for the years 2002 and 2004. Given are cumulated and weighted means, minimum (min) and maximum (max) of a $95 \%$ confidence interval for the control, clear cut and selected harvesting plots $(n=10)$ and the locations (nearby trunk, between trunk, undisturbed and disturbed organic layers, skidding trail, under crown and next to a stump, $n=5$ ). Numbers in parenthesis behind the locations refer to percentage of the locations surface to the plot area.

Table 2-6: Methane emissions $\left(\mathrm{mg} \mathrm{CH}_{4}-\mathrm{C} \mathrm{m}{ }^{-2}\right.$ ) for a 158 days period for treatments at Otterbach between 21st June and 26th November for the years 2002 and 2004. Given are cumulated and weighted means, minimum $(\min )$ and maximum (max) of a $95 \%$ confidence interval for the control, clear cut and selected harvesting plots $(n=10)$ and the locations (nearby trunk, between trunk, undisturbed and disturbed organic layers, skidding trail, under crown and next to a stump, $n=5$ ). Numbers in parenthesis behind the locations refer to percentage of the locations surface to the plot area

Table 3-1: $\quad$ Texture and soil chemical properties in $0-5 \mathrm{~cm}$ mineral soil depth at the plots choosen for treatment (clear cutting) and as control (mature stand) at Otterbach site before harvesting $(n=5)$. CEC = cation exchange capacity, BS = base saturation.

Table 3-2: $\quad$ Relative energy input $18 \mathrm{~m}$ before the tree base line and at the tree base line for both the south-west and north-west edge and the forest interior $(40 \mathrm{~m}$ behind tree base line) referred to radiation at the clear cut centre on a monthly cumulated basis.

Table 3-3: $\quad$ Mean soil temperatures $\left[{ }^{\circ} \mathrm{C}\right]$ in $10 \mathrm{~cm}$ depth, calculated for the forest interior, the clear cut centre and the annual average values.

Table 3-4: $\quad$ Parameters and residual sum of squares (rss) of the soil temperatures fitted with formula 1 for each direction.

Table 3-5: Width of transition zones for soil temperature, distances are given for both sides into the forest interior (negative) and onto the clear cut site (positive) in meter from tree base line.

Table 3-6: $\quad$ Areas $\left[\mathrm{m}^{2}\right]$ of clear cut centre, transition zones and total clear cut influenced area. The calculation was done for a square of $182 \mathrm{~m}$ with linear tree base line. Not included into the calculation are the transition zones of the south-east edge.

Table 3-7: $\quad$ Mean heterotrophic carbon dioxide emission based on soil temperatures and the Arrhenius kinetics for forest floor at Solling sites. The monthly zone emissions are calculated for a $100000 \mathrm{~m}^{2}$ big forest site. Two calculations are compared, where the first used three zones with variable extensions and the second used the two zones clear cut and forest with constant extensions of $33140 \mathrm{~m}^{2}$ and $66860 \mathrm{~m}^{2}$, respectively.

Tabelle 4-1: Textur und bodenchemische Messwerte Austauschbare Kationen (AKE), Basensättigung (BS), C, N und C-N-Verhälniss und Lagerungsdichte (LD) in der Nähe der vier Intensivmessfelder am Kahlschlag Otterbach für 5 und $20 \mathrm{~cm}$ Tiefe. 
Tabelle 4-2: Modellkonfiguration im Modellsystem Expert-N zur Wasserhaushaltsmodellierung der Ökotope des Kahlschlags Otterbach

Tabelle 4-3: Bilanz des Bestandsniederschlages für die Vegetationsperiode und im Winter unter Altbestand und unter Krone am Nordwestrand des Kahlschlages.....

Tabelle 4-4: Parameter der Pedotransferfunktionen nach van Genuchten für die fünf Simulationsschichten

Tabelle 4-5: Mittlere normierte Quadratwurzelabweichung (Normalised root mean square error, NRMSE) und Modell-Effizienz-Index (Modelling effeciency index, IA) angegeben für Matrixpotentiale und die abgeleiteten Wassergehalte an den vier Straten

Tabelle 4-6: Jährliche Wasserbilanzen für die ersten drei Jahre nach Durchführung des Kahlschlags (2005-2007)

Tabelle 4-7: Größen der Wasserhaushaltskomponenten im europäischen Vergleich (de Vries et al., 2006) und frühere Modellergebnisse für Studien unter Fichtenaltbestand im Hochsolling (Eckersten et al., 1995; Salihi, 1984)

Table 5-1: $\quad$ Soil properties of the investigation area divided in the cleared site (Plot I) and the undisturbed forest (Plot II)

Table 5-2: $\quad \mathrm{ECH}_{2} \mathrm{O}$ signals in different materials in \% of supply voltage [ $\mathrm{V}-1$ * 100$]$ 


\section{Inhaltsverzeichnis}

1

Einleitung $-1-$

1.1 Literaturübersicht $-8-$

Initial effects of harvesting on nitrous oxide and methane fluxes in a spruce forest.

Abstract $-11-$

Introduction $-12-$

Site description $-13-$

Material and Methods $-14-$

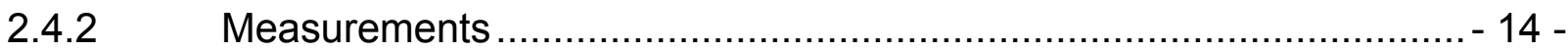

2.4.3 Flux estimates and statistical analyses.......................................... 15 -

2.5.2 Nitrous oxide emissions ................................................................... 18 -

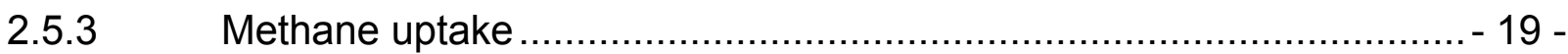

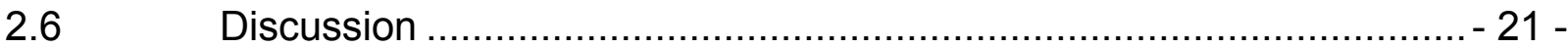

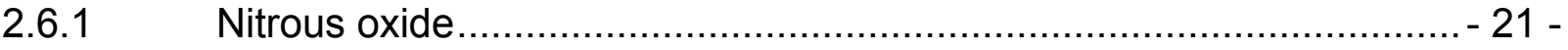

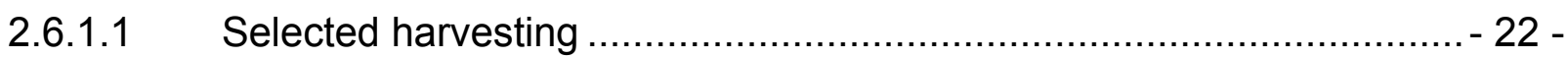

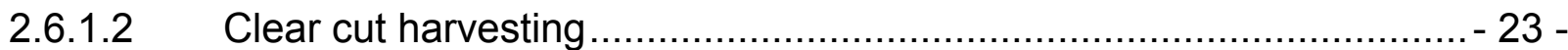

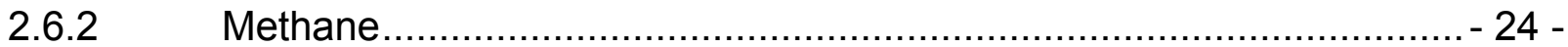

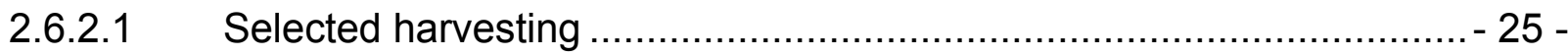

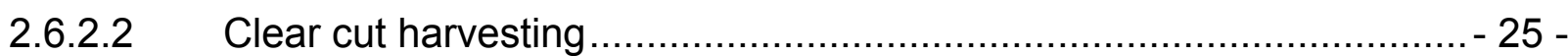

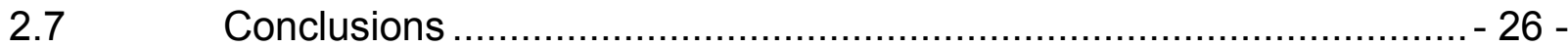

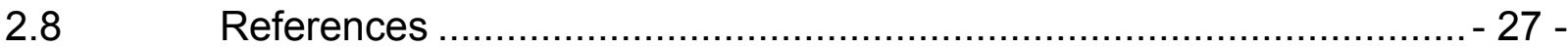

3 Temporal and spatial variations of two-sided edge effects on small

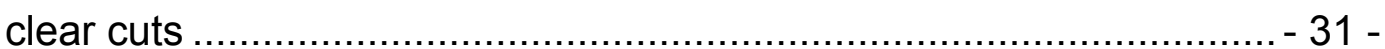

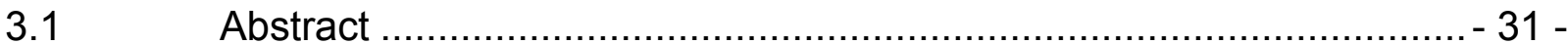

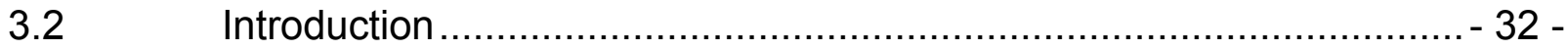

S.3 Site, material and methods ........................................................ 33 -

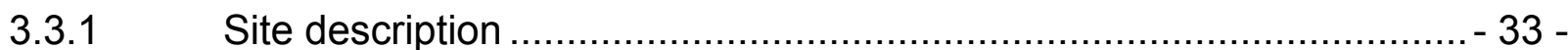

3.3.2 Material and Methods .................................................................. 33 -

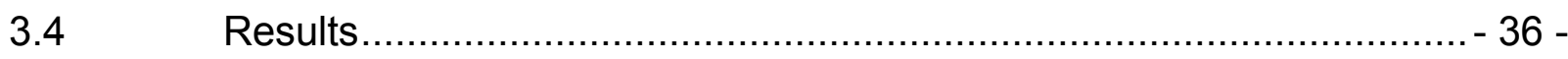

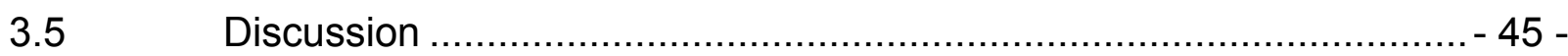

3.6 References .................................................................... 49 -

4 Räumliche Modifikationen des Bodenwasserhaushalts durch

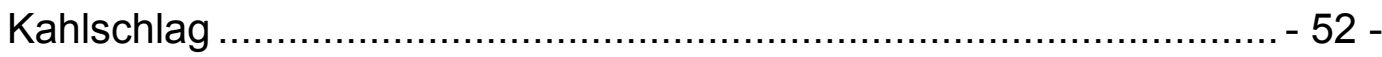

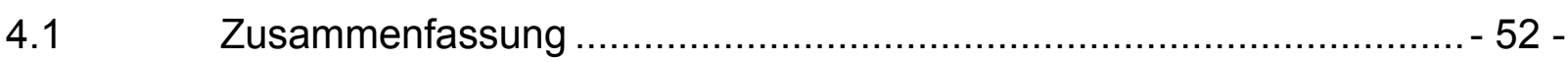

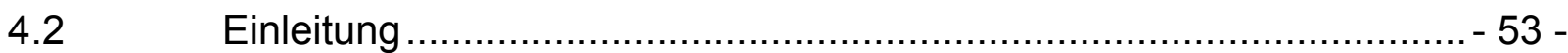

$4.3 \quad$ Untersuchungsraum ................................................................ 55 - 


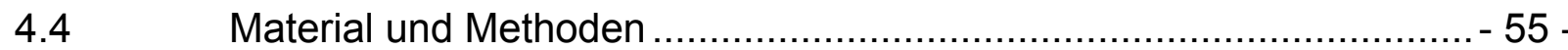

$4.5 \quad$ Ergebnisse und Diskussion .................................................... 59 -

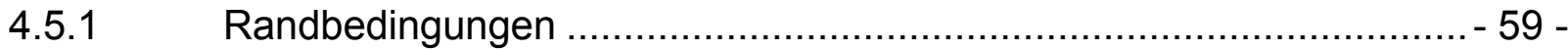

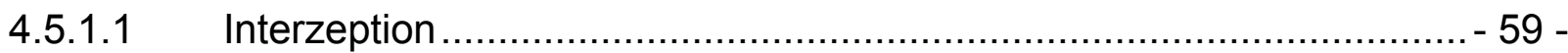

4.5.1.2 Bodenphysikalische Größen .................................................. 62 -

4.5.2 Messungen der Matrixpotentiale ................................................... 63 -

4.5.3 Modellergebnisse und Vergleich............................................... 64 -

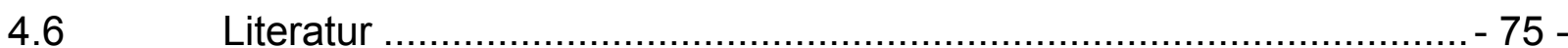

$5 \quad$ Management induced heterogeneity of soil water redistribution in forested areas........................................................................ - 79 -

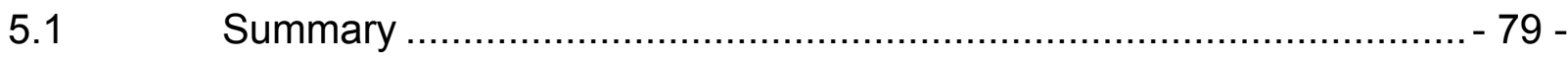

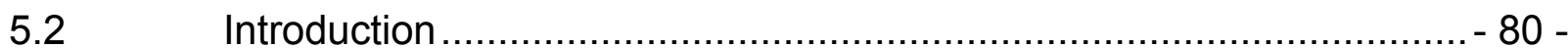

S.3 Site, Materials and Methods ...................................................... 80 -

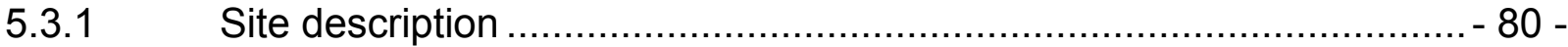

5.3.2 Instrumentation and data processing ...................................... 81 -

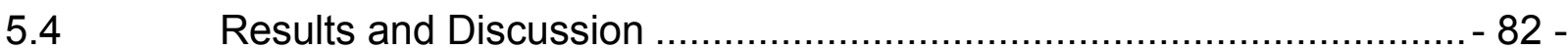

5.4.1 Calibration of the Capacitor dielectric surrounding sensor.................. 82 -

5.4.2 Soil moisture redistribution of two extraordinary hydrological events... - 85 -

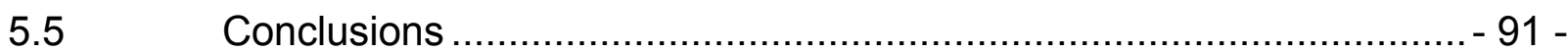

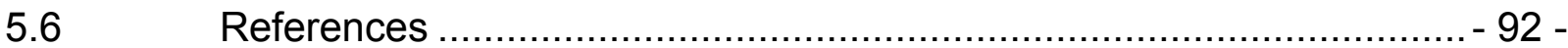

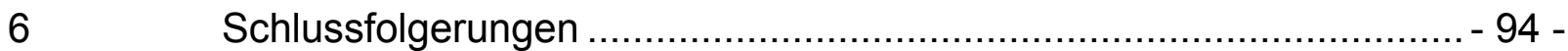

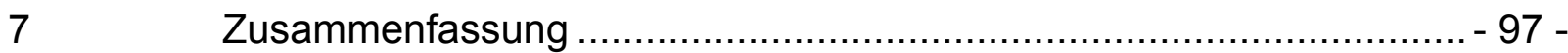

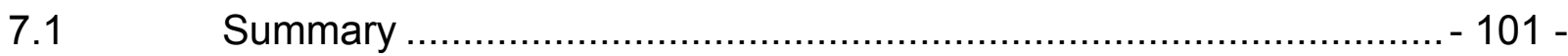




\section{Einleitung}

Das exponentielle Wachstum der Weltbevölkerung und die beschleunigte Intensivierung der wirtschaftlichen Tätigkeiten in den letzten Dekaden haben deutlich gemacht, dass dringend Strategien für eine nachhaltige Entwicklung erarbeitet werden müssen. Dies gilt sowohl für die globale und die lokale Ebene. Bezogen auf die Situation in Deutschland bedeutet dies, dass auch der Wald, der ca. $30 \%$ der Fläche bedeckt, als Produzent des nachwachsenden Rohstoffs Holz stärker als dies bisher der Fall war in die Betrachtung einbezogen werden muss. Die Nutzung des aufwachsenden Holzes hat in jedem Fall zur Folge, dass in das Ökosystem eingegriffen werden muss, sei es zur Bestandsbegründung, zur Bestandspflege oder zur Holzernte. Jeder dieser Eingriffe stellt eine Störung des Systems dar. Unter der Maxime der Nachhaltigkeit bedeutet dies, dass die Nebeneffekte der Eingriffe keine dauerhaften Schädigungen in den Waldökosystemen verursachen und keine Belastungen der Nachbarsysteme bedingen, die deren interne Kompensationsmechanismen überschreiten.

Unter dieser Maßgabe stellt heute die Vermehrung von Laub- und Mischwäldern ein vorrangiges Ziel waldbaulicher Maßnahmen in Deutschland dar. Dadurch sollen stabile Bestandsstrukturen geschaffen werden, welche Risiken durch Windwurf und Wasserstress sowie durch Schädlingsbefall begrenzen. Weiterhin sollen die Funktionen des Waldes im Wasser- und Stoffhaushalt optimiert sowie die Arten- und Habitatvielfalt (vgl. Bengtsson et al., 2000) genutzter Waldökosysteme vergrößert werden. Als übergeordnetes Ziel steht also eine Erhöhung der Naturnähe und Stabilität der Bestände. Zur Erreichung dieses Ziels ist auf großen Flächen der Umbau von Nadelholzreinbeständen erforderlich. Zur Veranschaulichung seien einige Zahlen aus Niedersachsen angeführt. So plant die Landesforstverwaltung in den nächsten vier Dekaden die Überführung von 47000 ha Fichten- und 26000 ha Kiefernreinbeständen in Laub- und Mischwälder.

Generell wird diese Überführung durch eine Zielstärkennutzung der Nadelholzbestände mit Laubholzunterbau angestrebt. In stark holzreichen Altbeständen, in windwurfgefährdeten Lagen oder bei der Überführung in Eichenbestände können jedoch andere Hiebformen wie Femel- oder Saumhiebe bis hin zu kleinen Kahlschlägen waldbauliche Alternativen sein. Diese letztgenannten Hiebformen zeichnen sich dadurch aus, dass ihre Anwendung mehr oder weniger große Lücken in den Altbeständen hinterlässt, die sich hinsichtlich ihres Mikroklimas, ihrer Vegetation und damit verbunden hinsichtlich ihres Wasser- und Stoffhaushaltes deutlich von den sie umgebenden Beständen unterscheiden. Innerhalb von Femellücken und Kleinkahlschlägen gibt es durch die sie umgebenden, 30-40 m hohen Altbestände randliche Effekte auf den Energie- und damit auf den Wasser- und Nährstoffhaushalt (vgl. Abb. 1-1), die zum Teil weit in die unbestockten Flächen hineinreichen. Diese 
lateralen Gradienten, die von der Größe und Form der Lücke, der Höhe der benachbarten Bäume sowie von der Himmelsrichtung und der Jahreszeit abhängig sind, sind damit auch in ihrer Ausprägung veränderlich (vgl. Ritter et al., 2005). In der Folge entstehen spezifische laterale Verteilungsmuster der Lichtverhältnisse sowie der Umsetzungs- und Transportprozesse in den Böden der Bestandslücken, die es hinsichtlich ihrer Konsequenzen für den nachfolgenden Bestand, für die verbleibenden angrenzenden Bäume, ökologisch zu beurteilen gilt. Besonders wichtig ist dies für den Wasserhaushalt sowie die biogeochemischen Kreisläufe von Kohlenstoff und Stickstoff mit den daran geknüpften Freisetzungen von Spurengasen. Die mikrobiellen Stoffumsetzungen hängen zwar von zahlreichen Umweltfaktoren ab, hierzu zählen zum Beispiel Textur, pH-Wert und Stickstoffverfügbarkeit (Firestone und Davidson, 1989), im Wesentlichen werden sie jedoch vom Wärme- und Wasserhaushalt des Bodens gesteuert. Beim Kahlschlag ist der Boden in den ersten Jahren der direkten Sonneneinstrahlung ausgesetzt, was zu seiner Erwärmung beiträgt. Gleichzeitig verdunstet aufgrund der zunächst spärlichen Bodenvegetation relativ wenig Wasser, was wiederum der Erwärmung entgegen wirkt. Beide Prozesse beeinflussen die Mineralisation der Streu und der organischen Substanz des Bodens.

Was die Freisetzung des treibhauswirksamen Spurengases Lachgas betrifft, gelten Waldböden der gemäßigten Breiten generell als untergeordnete Quellen (IPCC, 2007; Brumme et al., 1999). Im Zentrum eines Kahlschlags hingegen, findet in der initialen Phase eine stärkere N-Mineralisation bei geringer Stickstoffaufnahme durch die Vegetation statt, wodurch die Möglichkeit einer verstärkten Lachgasfreisetzung besteht. Hierauf weisen Untersuchungen an Böden durchforsteter Wälder im temperaten Bereich hin (Tate et al., 2006; Bradford et al., 2001). Im Gegensatz dazu wird für die netto Methanaufnahme eine Reduktion erwartet. Eine geringere Methanaufnahme wird durch eine erhöhte Stickstoffverfügbarkeit und eine geringere Durchlüftung des Bodens aus dem Zusammenwirken hoher Wassergehalte und teilweiser Verdichtung durch die Erntemaßnahmen begründet (Bradford et al., 2001).

Zur "Veränderungsdynamik von Waldökosystemen" und zur "Zukunftsorientierten Waldwirtschaft" wurden in den vergangenen Jahren mehrere Forschungsvorhaben durchgeführt, die sich mit der Wasser- und Stoffdynamik sowie der Vegetationsentwicklung in Kleinlücken befassen, wie sie bei der Zielstärken- und Femelbewirtschaftung entstehen (Gärtner und Reif, 2004; Bartsch et al., 2002; Weiss, 2002; Aboal et al., 2000; Vor, 1999; Mellert et al., 1998 und 1996; Bäumler and Zech, 1997; Hüser et al., 1996; v. Wilpert et al., 1996; Bauhus, 1994). Für die Wirkungen von Kleinkahlschlägen auf den Wasser- und Stoffhaushalt und deren beteiligte Prozesse finden sich in der Literatur nur relativ wenig Hinweise z.B. bei Zerva und Mencuccini, 2005; Högbom et al., 2002; Lee et al., 2002; Parfitt et al., 2002; Parfitt et al., 2001; Smolander et al., 2001; Breden, 1994; Nykvist, 1977; Likens et al., 1970. Die Problematik der an Kleinkahlschlägen auftretenden lateralen Gradienten wurde 
bisher nicht oder nur in Ansätzen untersucht, obwohl für die Ableitung flächenhafter Aussagen dies unbedingt notwendig ist. Für den nordwestdeutschen Raum liegen keine Informationen vor. Der Versuch, über empirische Modelle die Wirkung von Hiebmaßnahmen auf das Pflanzenwachstum, den Kohlenstoffspeicher des Bodens und den Wasserhaushalt zu simulieren, führte bisher nur für die Zielstärkennutzung zu zufrieden stellenden Ergebnissen (Lasch et al., 2005).

In der Abbildung 1-1 sind die Einflüsse und Bezüge zwischen Kahlschlag und umgebenden Bestand schematisch dargestellt.

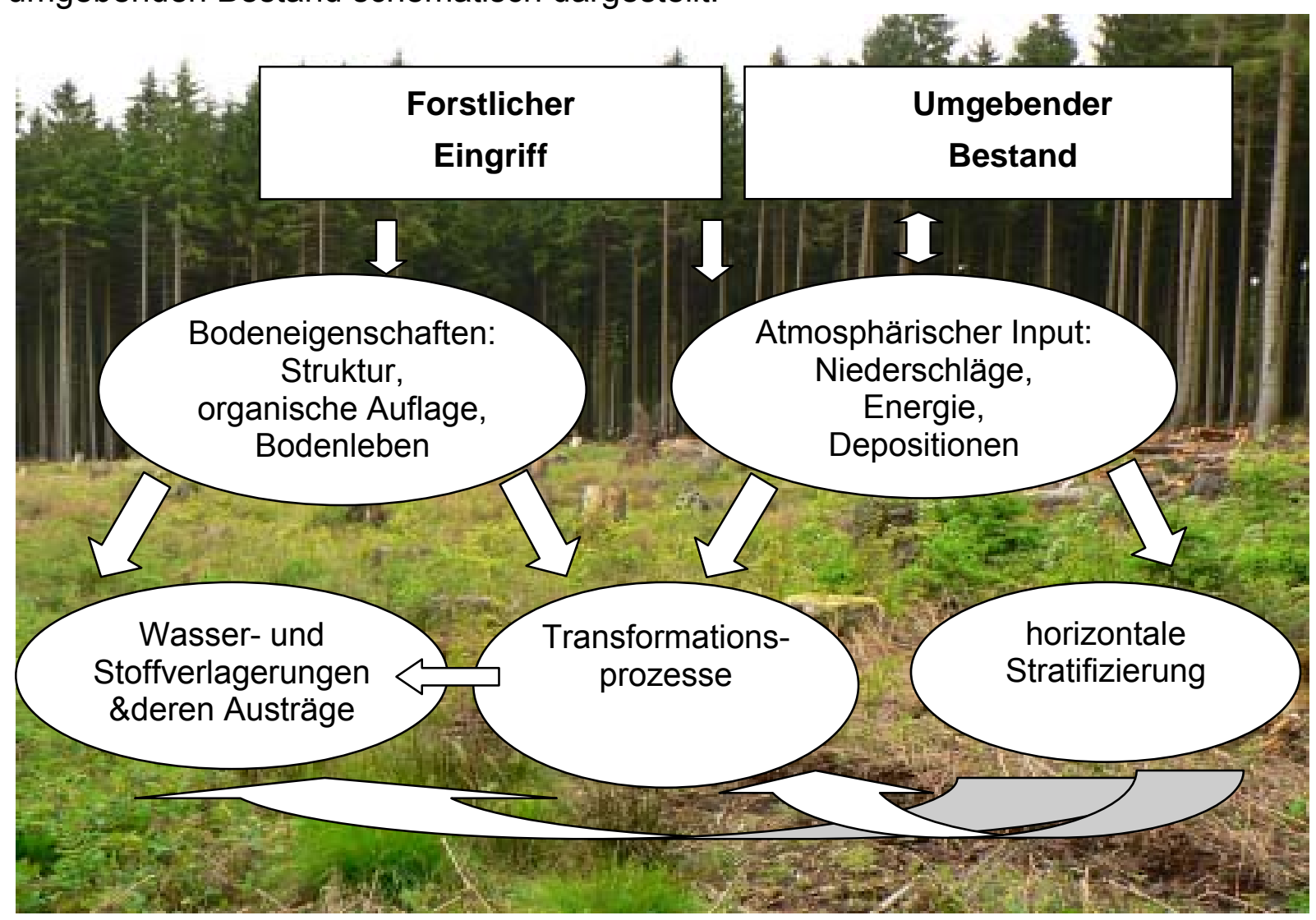

Abbildung 1-1: Blockbild des Wirkungsgefüges auf einem Kahlschlag und dem Bestand

Die wichtigsten Parameter des Wasserhaushalts eines Ökosystems sind die Niederschlagsmenge, eventuell auftretender Oberflächenabfluss, die Evaporation (Verdunstung von Oberflächen), die Transpiration (Wasserabgabe durch die Vegetation) und die Sickerwasserrate. Wie bei den Stoffumsätzen zeigt sich auch hierbei die enge Verknüpfung mit dem Energiehaushalt, da die zur Evaporation oder Transpiration benötigte Energie durch Strahlung geliefert werden kann oder lateral mit der Luft zugeführt wird. An Lücken und kleinen Freiflächen ist daher von einem komplexen Wirken des Energiehaushaltes durch diskrete Muster der Strahlungsverteilung aber auch durch lateralen Luftaustausch auszugehen. Demgegenüber steht die Reaktion der Pflanzen durch die Regulierung der Öffnungsweite ihrer Stomata. Diese können bei ungenügender Wasserversorgung reduziert oder bei hohen Temperaturen zur Kühlung der Blattorgane erweitert werden und so steuernd auf die Transpirationsraten einwirken. Für die Kahlschlagfläche bedeutet dies, dass aufgrund 
einer geringeren Transpiration und Interzeption der Bodenvegetation im Gegensatz zum Bestand mehr Wasser in tiefere Bodenschichten gelangt und die Grundwasserneubildungsrate ansteigen kann. Für die randständigen Bäume hingegen können erhöhter Strahlungseinfall, wärmere Luftströmungen und unveränderte Interzeption die Transpiration beeinflussen und im ungünstigsten Fall zu Wasserstress führen. Generell ist bei einem Umbau zu einem Bestand mit hohem Buchenanteil in der Folge eine höhere Grundwasserneubildungsrate zu erwarten (Armbruster et al., 2004; Benecke, 1984; Bosch und Hewlett, 1982).
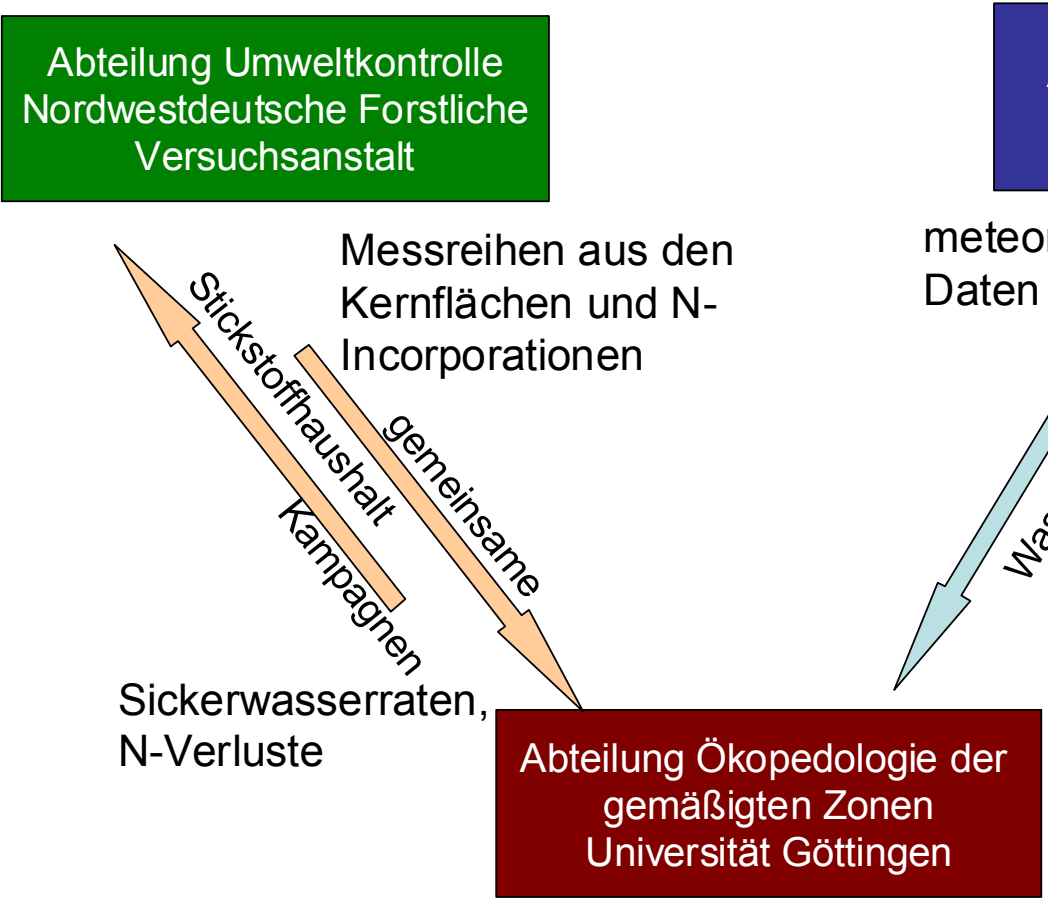

Abteilung Bioklimatologie

Universtiät Göttingen
Daten zu

Bodenstrukturen und räumlicher Varianz

\section{Abbildung 1-2: Organisation und Zusammenarbeit mit Trägern verbundener Teilprojekte}

Die Untersuchungen zur raumzeitlichen Dynamik der Parameter des Energie-, Wasser- und Spurengashaushaltes wurden modellhaft an einem mit Fichten bestockten Kahlschlag (1 ha Kernfläche, 1.56 ha Rand) im Solling durchgeführt. Dieser Standort befindet sich an einem leicht geneigten Hang des Berglandes aus Buntsandstein in $300 \mathrm{~m}$ über NN. In einem Verbund von drei Vorhaben wurden unterschiedliche Fragestellungen zum Stoff- und Energiehaushalt sowie zur Mikrometeorologie untersucht und die erhobenen Daten und Ergebnisse ausgetauscht (s. Abb. 1-2). Die hier gezeigten raumzeitlichen Muster des Energie-, Wasser- und Stoffhaushaltes der Freifläche und der benachbarten Altbestände und ihre modellhafte Beschreibung sollen dazu dienen, die nutzungsbedingten Effekte räumlich zuordnen 


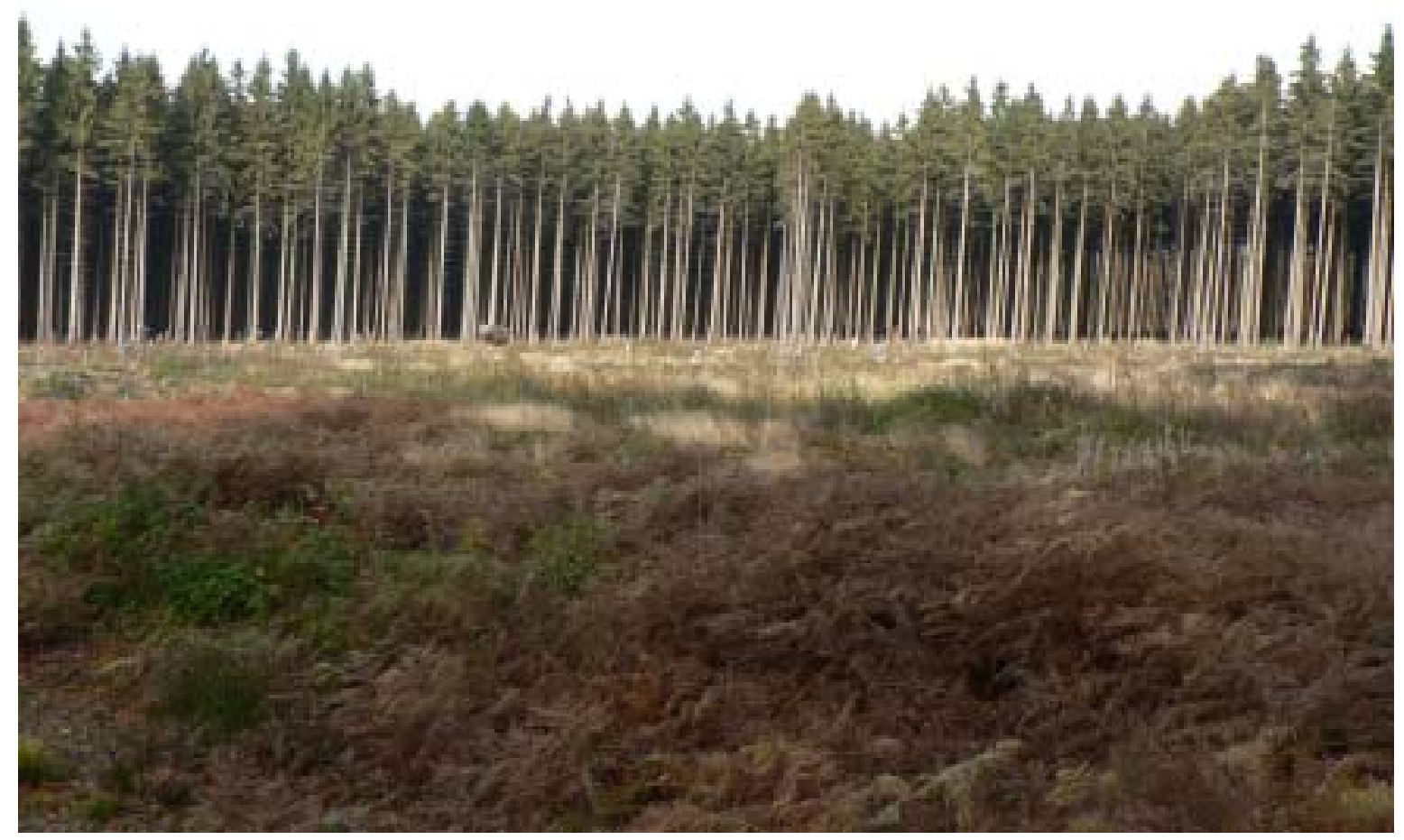

Abbildung 1-3: Die Kahlschlagfläche Otterbach im Solling im 2. Jahr nach der Hiebmaßnahme mit dem Wechsel von beschattetem zu besonnten bereich.

und ökologisch beurteilen zu können. Einen Eindruck der Kahlschlagfläche im 2. Jahr nach dem Hieb vermittelt Abbildung 1-3. Auf ihr ist ein ausgedehnter beschatteter Bereich im Vordergrund zu erkennen und der besonnte Waldrand im Hintergrund. Die Abbildung 1-4, entstand im 4. Jahr nach dem der Durchführung des Kahlschlags und verdeutlicht die Dynamik der Vegetationsentwicklung auf der Freifläche.

Durch die Erfassung des Ausgangszustands und der Effekte im Anfangsstadium eröffnet sich die Möglichkeit, das Umsatzgeschehen auch langfristig zu verfolgen. Außerdem finden Bemühungen um eine exaktere Beschreibung von Lückendynamiken in jüngster Zeit auch im tropischen (Marthews et al., 2008) und borealen Klimabereich (Vepakomma et al., 2008) statt, so dass Prozessgrößen und ihre räumliche Verteilung in Zukunft über die verschiedenen Klimazonen verglichen werden können.

Die Arbeit gliedert sich in die Themenbereiche:

1. Initiale Effekte unterschiedlicher Hiebformen auf Spurengasemissionen

2. Raumzeitliche Variabilität der Randeffekte beidseitig der Baumkronenlinie eines Kleinkahlschlags

3. Räumliche Modifikationen des Bodenwasserhaushalts nach Kahlschlag

4. Durch forstliches Management induzierte Heterogenität der Bodenwasserumverteilung in bewaldeten Gebieten 


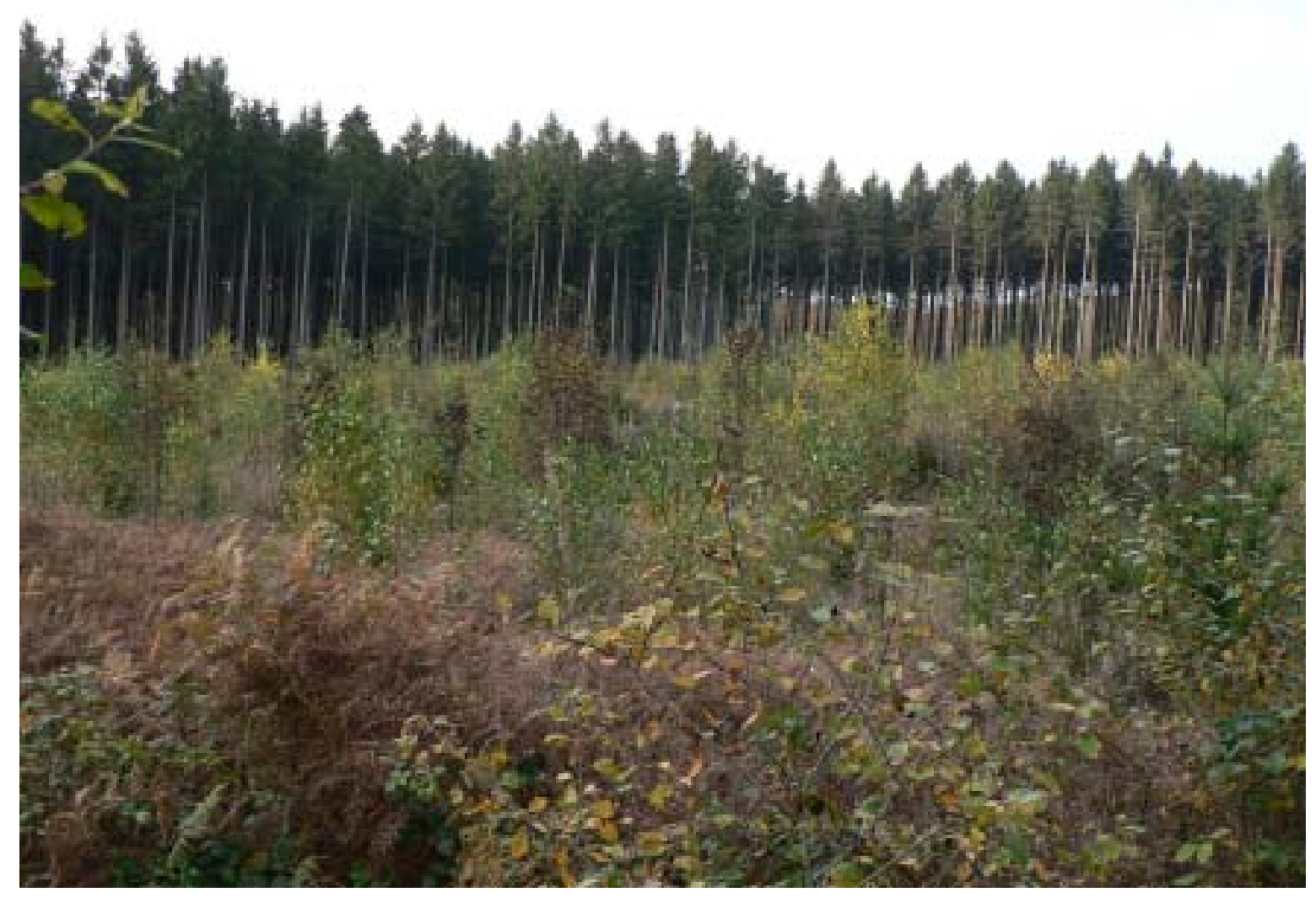

Abbildung 1-4: Die Kahlschlagfläche Otterbach im Solling im 4. Jahr nach der Hiebmaßnahme mit starker Entwicklung von Pionierpflanzen.

Folgende übergeordnete Hypothesen liegen den Untersuchungen zugrunde:

Zu 1. Das Maß der Störung durch forstwirtschaftliche Maßnahmen beeinflusst graduell die bodenbürtigen Spurengasemission von Lachgas $\left(\mathrm{N}_{2} \mathrm{O}\right)$ und Methan $\left(\mathrm{CH}_{4}\right)$ vom Altbestand über die Zielstärkennutzung bis zum Kahlschlag. Die Verteilung der Ernterückstände, Bodenverdichtung und Unterschiede in atmosphärischem Eintrag führen zu diskreten räumlichen Einheiten, die sich durch spezifische $\mathrm{N}_{2} \mathrm{O}$ - und $\mathrm{CH}_{4}$-Emissionen auszeichnen. Basierend auf diesen räumlichen Unterschieden ist es nötig, diese Stratifizierungen in den Emissionsraten des ganzen Geländes zu berücksichtigen.

Zu 2. Der umgebende Altbestand verursacht ein dynamisches Muster der Beschattung bzw. der Besonnung, was sich im Energie-, Wasser- und Stoffhaushalt der Böden der Freifläche widerspiegelt. Dies ist bei ökologischen Bewertungen und Maßnahmen zu berücksichtigen.

Zu 3 Auf Kleinkahlschlägen repräsentieren Messungen im Zentrum nicht das hydrologische Geschehen auf der Gesamtfläche. Der verbleibende Altbestand beeinflusst erhebliche Flächenanteile des Kleinkahlschlags, was sich nicht nur in der Verteilung der Niederschläge auswirkt, sondern auch auf die Evapotranspiration und die Grundwasserspende. Auch der Altbestand wird in seinen Randbereichen hinsichtlich des Wasserhaushaltes beeinflusst. Ein Kahlschlag kann hinsichtlich des 
Wasserhaushaltes nicht als Einheit angesehen werden, sondern bedarf einer räumlich und zeitlich differenzierten Betrachtung.

Zu $4 \quad$ Unterschiede im Energie- und Wasserhaushalt zwischen Bestand und Freifläche beeinflussen den Wassertransport in Böden. Bypasstransport findet aufgrund höherer Wassersättigung verstärkt auf der Freifläche statt.

Die Arbeiten zu diesen vier Themenbereichen sind jeweils in Form eines Artikels verfasst und in dieser Form im Folgenden präsentiert. 


\subsection{Literaturübersicht}

Aboal J.R., M.S. Jiménez, D. Morales and P. Gil, 2000. Effects of thinning on throughfall in Canary Islands pine forest - The role of fog. J. of Hydrology 238, 218-230.

Armbruster M., J. Seegert and K.-H. Feger. 2004. Effects of changes in tree species composition on water flow dynamics - Model applications and their limitations. Plant and Soil, 264, 13-24.

Bartsch N., J. Bauhus and T. Vor. 2002. Effects of group selection and liming on nutrient cycling in an European beech forest on an acidic soil. In: Dohrenbusch, A. and N. Bartsch (eds.): Forest development - Succession, environmental stress and forest management. Springer, Berlin, 109-142.

Bauhus J. 1994. Stoffumsätze in Lochhieben. Ber. Forschungszentrum Waldökosysteme, Göttingen, Reihe A, Bd. 113, 1-181.

Bäumler R. and W. Zech. 1997. Atmospheric deposition and impact of forest thinning on the throughfall on mountain forest ecosystems in the Bavarian Alps. Forest Ecol. Managem. 95, 243-251.

Benecke P. 1984. Der Wasserumsatz eines Buchen- und eines Fichtenwaldökosystems im Hochsolling. Schriften aus der Forstlichen Fakultät der Universität Göttingen und der Niedersächsischen Forstlichen Versuchsanstalt ; 77. Sauerländer Verlag, Frankfurt a. Main.

Bengtsson J., S.G. Nilsson, A. Franc and P. Menozzi. 2000. Biodiversity, disturbances, ecosystem function and management of European forests. Forest Ecol. Managem. 132, 39-50.

Bosch J.M. and J.D. Hewlett. 1982. A review of catchment experiments to determine the effect of vegetation changes on water yield and evapotranspiration. J. Hydrol. 55, 3-23.

Bradford M.A., P. Ineson, P.A. Wookey, and H.M. Lappin-Scott. 2001. Role of $\mathrm{CH}_{4}$ oxidation, production and transport in forest soil $\mathrm{CH}_{4}$ flux. Soil Biol. Biochem. 33, 1625-1631.

Breden M. 1994. Ion leaching and soil acidification in a forest Haplic Podzol: Effects of nitrogen application and clear-cutting. Report 73, Swedish University of Agricultural Scienes, Uppsala.

Brumme R., W. Borken and S. Finke. 1999. Hierarchical control on nitrous oxide emission in forest ecosystems, Global Biochemical Cycles 13, 1137-1148.

Firestone M.K. and E.A. Davidson. 1989. Microbial basis of $\mathrm{NO}$ and $\mathrm{N}_{2} \mathrm{O}$ production and consumption in soil. In Andreae, M.O. and D.S. Schimmel (eds) Exchange of Trace gases between terrestrial ecosystems and the atmosphere, 7-21, John Wiley \& Sons, New York.

Gärtner S. and A. Reif. 2004. The impact of forest transformation on stand structure and ground vegetation in the southern Black Forest, Germany. Plant and Soil, 264, 35-51.

Högbom L., U. Nilsson and G. Örlander. 2002. Nitrate dynamics after clear felling monitored by in vivo nitrate reductase activity (NRA) and natural ${ }^{15} \mathrm{~N}$ abundance of Deschampsia flexuosa (I.) Trin. Forest Ecol. Managem. 160, 273-280.

Hüser R., H.W. Führer und K.E. Rehfuess. 1996. Wasserchemische Auswirkungen von Hiebseingriffen im Krofdorfer Buchenforst. Forst u. Holz 51, 666-672.

IPCC, 2007. Climate Change 2007. The scientific basis. Cambridge University Press, London. 
Lasch P., F.-W. Badeck, F. Suckow, M. Lindner and P. Mohr. 2005. Model-based analysis of management alternatives at stand and regional level in Brandenburg (Germany). Forest Ecol. Managem. 207, 59-74.

Lee J., I.K. Morrison, J.D. Leblanc, M.T. Dumas and D.A. Cameron. 2002. Carbon sequestration in trees and regrowth vegetation as affected by clearcut and partial cut harvesting in a second-growth boreal mixedwood. For. Managem. Ecol. 169, 83-101.

Likens G.E., F.H. Bormann, N.M. Johnson, D.W. Fischer and R.S. Pierce. 1970. Effects of forest cutting and herbicide treatment on nutrient budgets in the Hubbard Brook watershed-ecosystem. Ecological Mongraphs 40, 1, 23-47.

Marthews T.R., D.F.R.P. Burslem, S.R. Paton, F. Yanyuez and C.E. Mullins. 2008. Soil drying in a tropical forest: Three distinct environments controlled by gap size. Ecological Modelling 216 (3-4), 369-384.

Mellert K.-H., C. Kölling und K.E. Rehfuess. 1996. Stoffauswaschung aus Fichtenwaldökosystemen Bayerns nach Sturmwurf. Forstw. Cbl. 115, 363-377.

Mellert K.-H., C. Kölling und K.E. Rehfuess. 1998. Vegetationsentwicklung und Nitrataustrag auf 13 Sturmwurfflächen in Bayern. Forstarchiv 69, 3-11.

Nykvist N. 1977. Changes in the amounts of inorganic nutrients in the soil after clear-felling. Silva Fennica 11, 224-229.

Parfitt R.L., G.J. Salt and L.F. Hilt. 2002. Clear-cutting reduces nitrate leaching in a pine plantation of high natural $\mathrm{N}$ status. Forest Ecol. Managem. 170, 43-53.

Parfitt R.L., G.J. Salt and S. Sagger. 2001. Post-harvest residue decomposition and nitrogen dynamics in Pinus radiata plantations of different N status. Forest Ecol. Managem. 154, 55-67.

Ritter E., L. Dalsgaard and K.S. Einhorn. 2005. Light, temperature and soil moisture regimes following gap formation in a semi-natural beech-dominated forest in Denmark. Forest Ecol. Managem. 206, 15-33

Smolander A., V. Kitunen and E. Malkönen. 2001. Dissolved soil organic nitrogen and carbon in a Norway spruce stand and an adjacent clear-cut. Biol. Fertil. Soils 33, 190-196.

Tate K.R., D.J. Ross, N.A. Scott, N.J. Rodda, J.A. Townsend and G.C. Arnold. 2006. Post-harvest patterns of carbon dioxide production, methane uptake and nitrous oxide production in a Pinus radiata D. Don plantation. Forest Ecol. Manage. 228, 40-50.

v. Wilpert K., M. Köhler und D. Zirlewangen. 1996. Die Differenzierung des Stoffhaushaltes von Waldökosystemen durch waldbauliche Behandlung auf einem Gneisstandort des Mittleren Schwarzwaldes. Mittlgn. Forstl. Versuchs- und Forschungsanstalt Baden-Württemberg 197, 1-94.

Verpakomma U., St-O. Benoit and D. Kneeshaw. 2008. Spatially explicit characterization of boreal forest gap dynamics using multi-temporal lidar data. Remote Sensing of Environment, 112 (5), 23262340 . 
Vor T. 1999. Stickstoffkreislauf eines Buchenaltbestandes nach Auflichtung und Kalkung. Ber. Forschungszentrum Waldökosysteme, Reihe A, 163, 11-153.

Weiss W. 2002. Nitrataustrag bei der Verjüngung von Fichten-Altbeständen: Welchen Einfluss hat der Standort? In: 7. Statusseminar des Kuratoriums der Bayrischen Staatsforstverwaltung, 16.5.2002, Landesanstalt für Wald- und Forstwirtschaft.

Zerva A. and M. Mencuccini. 2005. Short-term effects of clearfelling on soil $\mathrm{CO}_{2}, \mathrm{CH}_{4}$, and $\mathrm{N}_{2} \mathrm{O}$ fluxes in a Sitka spruce plantation. Soil Biol. Biochem. 27, 2025-2036. 


\title{
2 Initial effects of harvesting on nitrous oxide and methane fluxes in a spruce forest
}

\author{
D. Fröhlich ${ }^{1}$, R. Brumme ${ }^{2}$, U. Klinck ${ }^{3}$, J. Prenzel ${ }^{1}$, F. Beese ${ }^{1}$ \\ 1 Universität Göttingen, Büsgen-Institut, Department of Soil Science of Temperate and Boreal \\ Ecosystems, Büsgenweg 2, 37077 Göttingen, Germany \\ 2 Universität Göttingen, Büsgen-Institut, Department of Soil Science of Tropical Ecosystems, \\ Büsgenweg 2, 37077 Göttingen, Germany \\ 3 Nordwestdeutsche Forstliche Versuchsanstalt, Abt. Umweltkontrolle, Grätzelstraße 2, 37079 \\ Göttingen, Germany
}

Key words: nitrous oxide, methane, Norway spruce, clear cut, skidding trail, logging

Corresponding author: Daniel Fröhlich

\subsection{Abstract}

Trace gas fluxes from forest soils are influenced by forest management as liming and forest harvesting, but there is only little information about how different intensities of harvesting can diminish the effect on trace gas fluxes. The effect of clear cutting and selected harvesting on the trace gas fluxes were studied at a spruce forest (Otterbach) at Solling site (Germany). In a clear cut plot, trees were completely removed and the debris was crushed and spread on the skidding trails. On the selected harvesting plot $28 \%$ of the trees were removed and the debris remained at the harvesting sites. Measurements of $\mathrm{N}_{2} \mathrm{O}$ and $\mathrm{CH}_{4}$ were conducted during growing seasons before (2002) and after (2004) harvest at three plots each of control (no harvest), clear cut, and selected harvesting. At each plot flux measurements were conducted at different locations: close to a trunk and between trunks at control plots; undisturbed and disturbed soil surface layers and skidding trails at clear cut plots; under crown and in stump vicinity locations at selected harvesting plots. The spatial fractions of these locations on each plot were used to estimate the mean flux rate of the plots.

Clear cut harvesting increased soil temperature, moisture content and $\mathrm{N}_{2} \mathrm{O}$ emissions (from 23 to $111 \mathrm{mg} \mathrm{N}_{2} \mathrm{O}-\mathrm{N} \mathrm{m}^{-2} 158 \mathrm{~d}^{-1}$ ) and decreased the uptake of $\mathrm{CH}_{4}$ (from 165 to $30 \mathrm{mg} \mathrm{CH}_{4}-\mathrm{C} \mathrm{m}^{-2} 158 \mathrm{~d}^{-1}$ ) when compared to the control plot. The skidding trails contributed to only $20 \%$ of the total area but compaction and availability of carbon from the organic debris reduced the total uptake of $\mathrm{CH}_{4} . \mathrm{N}_{2} \mathrm{O}$ emissions from skidding trails were significantly higher. Selected harvesting did not change the fluxes of $\mathrm{CH}_{4}$ but of $\mathrm{N}_{2} \mathrm{O}$. The changes in the $\mathrm{N}_{2} \mathrm{O}$ fluxes in the stump vicinity had only a small effect on the total flux from the whole area. The uptake rates of $\mathrm{CH}_{4}$ at stump vicinity and the control plots were not different. 


\subsection{Introduction}

Nitrous oxide $\left(\mathrm{N}_{2} \mathrm{O}\right)$ is a very effective greenhouse gas which contributes to about $6 \%$ to global warming (IPCC, 2007) and to the destruction of the ozone layer of the stratosphere (Crutzen, 1981; Lashof and Ahuja, 1990). Terrestrial soils are considered to be one of the major sources of $\mathrm{N}_{2} \mathrm{O}$ emissions. Forests of temperate zones have been found as minor sources due to wide spread nitrogen deficiency and low $\mathrm{N}$-turnover rates. However in regions with high nitrogen deposition and in drained organic soils high rates of $\mathrm{N}_{2} \mathrm{O}$ emission showing a distinct seasonal pattern were observed (Maljanend et al., 2003; Schulte-Bisping et al., 2003, Brumme et al., 1999).

On global scale terrestrial soils consume up to $10 \%$ of the total global $\mathrm{CH}_{4}$ emissions (Adamsen and King, 1993). High $\mathrm{CH}_{4}$ oxidation rates only were found at sites with high biological activity while most forest soils have low uptake rates (Brumme and Borken, 1999). The fluxes of $\mathrm{N}_{2} \mathrm{O}$ and $\mathrm{CH}_{4}$ are affected by environmental parameters such as soil water filled pore space, soil temperature, soil $\mathrm{pH}$, nitrogen availability, litter decomposition, atmospheric $\mathrm{N}$-deposition, precipitation and soil texture among others (Firestone and Davidson, 1989). Some of these factors show a high temporal and spatial variability. Investigations of soil solution (Gundersen et al., 1995) as well as throughfall chemistry (Seiler and Matzner, 1995) showed correlations to stem distance. The $\mathrm{pH}$ values close to Norway spruce stems are depressed (Pallent and Riha, 1991; Friedrich, 1992) and available carbon exhibits association with the existence of fine roots (Hendrickson and Robinson, 1984). $\mathrm{NO}_{3}-\mathrm{N}$ concentrations are lower next to spruce stems than in distance to them (Koch and Matzner, 1993). Therefore we hypothesize that in older spruce monocultures the areas around the stem and between the trees and in small gaps differently contribute to the plot emission. It is expected, that the areas next to the stem lead to lower $\mathrm{N}_{2} \mathrm{O}$ emission and higher $\mathrm{CH}_{4}$ uptake than the more distant areas because of the differences in nitrogen availability and the effects of soil moisture and soil $\mathrm{pH}$.

As an effect of tree harvesting a drastic change of the fluxes of soil born trace gas is expected, this is supported by some studies in temperate forest ecosystems (Tate et al., 2006; Zerva and Mencuccini, 2005; Bradford et al., 2001; Ojima et al., 1993). The most commonly applied methods for harvesting spruce trees are single tree or clear cut harvesting. Harvesting causes a sudden increase of precipitation and irradiance (Ritter et al., 2005) due to interruption of transpiration and decreased interception of both water and light. An increase of soil moisture and soil temperature can enhance decomposition and mineralization processes (Moore, 1986) by affecting microbial activity (Bäckmann et al., 2004) and microbial biomass (Lundgren, 1982) and also may influence trace gas fluxes (Schimmel and Gulledge, 1998). On the other hand the growth of ground vegetation is promoted (Kompa, 2004) and availability of nitrogen for microorganisms may be reduced, reducing the nitrous gaseous losses. However, amount and species diversity of understory plants are depending on the 
degree of disturbances during harvest (Berger et al., 2004). Moreover active fine root biomass shows negative trends with an increasing size of the gap (Welke et al., 2003). Also alterations of the key parameters (temperature, soil moisture, nitrogen concentration) are depending on harvesting intensity (Barg and Edmonds, 1999). Therefore we expect that the degree of disturbance affects the trace gas release or uptake gradually from the undisturbed site over selected harvesting to clear cut. The distribution of logging debris and compaction of the skidding lines affect the soil properties which enhances the trace gas exchange with the atmosphere. This guides to the hypothesis that harvesting leads to a distinct pattern of spatial unities with specific matter turnover and specific $\mathrm{N}_{2} \mathrm{O}$ emission and $\mathrm{CH}_{4}$ uptake rates. This stratification has to be regarded when the exchange rates of trace gasses of the whole site is calculated.

The aim of this study was to test the above mentioned hypothesis and assumptions by measuring the $\mathrm{N}_{2} \mathrm{O}$ and $\mathrm{CH}_{4}$ exchange before and after the application of different harvesting strategies in a spruce forest.

\subsection{Site description}

We performed our investigations at a mature spruce stand located in the Solling area about $60 \mathrm{~km}$ in the Northwest of Göttingen (51 $46^{\prime}$ N. Lat., $9^{\circ} 27^{\prime}$ E. Long.). The stand at the site called Otterbach was 85 years old and is located at an altitude of $310 \mathrm{~m}$. The mean annual temperature and annual precipitation were $7.4{ }^{\circ} \mathrm{C}$ and $970 \mathrm{~mm}$. Meteorological data from the nearest weather station (about $15 \mathrm{~km}$ from the site) are presented in Table 2-1.

Table 2-1: $\quad$ Precipitation and air temperature at Solling weather station (Silberborn) on a long term basis and for years of investigation on an annual basis and for growing season

\begin{tabular}{|c|c|c|c|c|c|}
\hline \multirow[b]{2}{*}{ year } & \multicolumn{3}{|c|}{--------------- precipitation [mm] --------------- } & \multicolumn{2}{|c|}{------ temperature $\left[{ }^{\circ} \mathrm{C}\right]$------ } \\
\hline & annual & growing season & $\%$ growing season & annual & growing season \\
\hline 1961-1990 & 1090 & 565 & 52 & 6.4 & 12.8 \\
\hline 2002 & 1339 & 666 & 50 & 7.8 & 12.8 \\
\hline 2004 & 1170 & 598 & 51 & 7.3 & 12.4 \\
\hline
\end{tabular}

The soil has been classified as Dystric Cambisol with low $\mathrm{pH}\left(\mathrm{H}_{2} \mathrm{O}\right)$ values (between 3.6 and 4.0), C: $\mathrm{N}$ ratios around 20 in $0-5 \mathrm{~cm}$ depth and low base saturation that did not exceed $12 \%$ (Tab. 2-2). The primary texture component is silt and the soil has derived from Triassic sandstone, covered by loess (about $30 \mathrm{~cm}$ ). Hydromorphic features at about 60-90 cm depth indicate a compact layer and the site has a slight slope to Northeast $\left(<3^{\circ}\right)$. 
Table 2-2: Texture and soil chemical properties in $0-5 \mathrm{~cm}$ mineral soil depth at the investigated plots $(n=5)$ before harvesting

\begin{tabular}{lrrrrrrrrr}
\hline \multirow{2}{*}{ Plot } & \multicolumn{2}{c}{ Clay Silt Sand } & $\begin{array}{c}\mathrm{CEC} \\
{\left[\mathrm{mmol} \mathrm{kg}^{-1}\right]}\end{array}$ & $\begin{array}{c}\mathrm{BS} \\
{[\%]}\end{array}$ & $\begin{array}{l}\mathrm{C} \quad \mathrm{N} \\
-\left[\mathrm{g} \mathrm{kg}^{-1}\right]\end{array}$ & $\mathrm{C} / \mathrm{N}$ & $\mathrm{pH}\left(\mathrm{H}_{2} \mathrm{O}\right)$ \\
\hline control (silt) & 11 & 82 & 7 & 84 & 12 & 62 & 3.0 & 21 & 3.6 \\
clear cut (silt) & 11 & 80 & 9 & 80 & 10 & 42 & 2.2 & 19 & 3.5 \\
selected harvesting (silt) & 7 & 88 & 5 & 115 & 12 & 76 & 3.9 & 19 & 3.9 \\
\hline
\end{tabular}

\subsection{Material and Methods}

\subsubsection{Experimental set-up}

The investigations were performed at three plots with different treatments. These plots covered an area of about $100 \mathrm{~m} \times 100 \mathrm{~m}$. One treatment was cleared (clear cut) and at another plot only single trees were removed (selected harvesting) in autumn 2003. The third plot was left unchanged as control. During selected harvesting $28 \%$ of the trees were removed. Tree felling was done by a harvester and the coarse debris from cut trees at the clear cut plot was completely crushed distributed on the skidding trail. The layer at the skidding trail amounted to about $60 \mathrm{~cm}$ height. On selected harvesting plots the debris was not removed. Disturbances of the surface organic layer of the non-trafficking area occurred during removing of the trees.

\subsubsection{Measurements}

$\mathrm{N}_{2} \mathrm{O}$ and $\mathrm{CH}_{4}$ fluxes were measured before harvest in 2002 and after harvest in 2004 , using cylindrical chambers of $27 \mathrm{~cm}$ in diameter and a height of $25 \mathrm{~cm}$. Ten chambers were installed at each of the three plots, five close to trunks and five between trunks, in May 2002. Before harvesting the chambers were removed from the clear cut and selected harvesting plot in autumn 2003. They were replaced in stump vicinity of removed trees and under the crown of a surrounding tree at the selected harvesting plot. At the clear cut plot chambers were replaced at locations with disturbed and undisturbed surface organic layers. Additional five chambers were placed on the skidding trails at the clear cut plot. The contribution of locations with disturbed and undisturbed organic layers and the contribution of the skidding trails to the fluxes of the total area were determined by their appearance along two $150 \mathrm{~m}$ diagonal transects in the clear cut. Disturbed areas were characterised by the absence of the forest floor, undisturbed areas by the presence of the forest floor, which was proved visually every $10 \mathrm{~cm}$.

Gas flux measurements were conducted at 2-4 week intervals from June 21st to November 26th in 2002 and 2004. During the measurement the chambers were closed with flat covers for 40 minutes. Within this time interval three gas samples $(0,20$ and $40 \mathrm{~min})$ were taken by using evacuated glass bottles $(100 \mathrm{ml})$. Before taking gas samples, the tightness of the bottles was checked by air pressure measurement using a sampling devise (Loftfield et al., 1997). Concentrations of $\mathrm{N}_{2} \mathrm{O}$ 
and $\mathrm{CH}_{4}$ in the samples were determined with an automated gas chromatographic system as described by Loftfield et al. (1997).

Additional measurements were conducted during gas sampling in the vicinity of the chambers. Soil temperatures were determined at $5 \mathrm{~cm}$ depth. Extractable ammonium and nitrate was measured in 0-10 cm depth $(n=3)$ in the year 2004 .

The penetration resistance was measured in the soil profile with a column penetrometer (Fa. Eijkelkamp; Knittel and Stanzel, 1976). 8 replicates were made at each plot. The beginning of a compacted layer was defined by the excess of $2.5 \mathrm{MPa}$ penetration resistance because in the investigations of Borchert and Graf (1988) on numerous German soils showed $15 \%$ or less water content at this resistance point.

\subsubsection{Flux estimates and statistical analyses}

Cumulated emissions of $\mathrm{N}_{2} \mathrm{O}$ and $\mathrm{CH}_{4}$ were calculated for the period between June 21st to November 26th for the years 2002 and 2004, respectively. To calculate the cumulative emissions, linear intersections between the dates of measurement were build and integrated for each chamber. The different locations were represented by 5 chambers each. For plot emissions the cumulative fluxes of the locations were weighted by a bootstrap procedure (Efron and Tishirani, 1993). With this procedure, a population was generated by repeated randomly drawing from the measurements and a factor, which determined the frequency of the drawing from one of the groups by their spatial fractions. The fractions were $50 \%$ for nearby and between trunk locations for untreated plots, $28 \%$ for stump vicinities at selected harvesting plot, $72 \%$ for the locations under the crown of surrounding trees at selected harvesting plot, and $70 \%$, $10 \%$ and $20 \%$ for the undisturbed, disturbed and skidding trail locations at the clear cut plot. These percentages refer to the allotment of removed trees at selected harvesting plot, to the inventory along transects in the clear cut and to estimations at the control plot.

The cumulated fluxes of the plots and the locations were tested for normal distribution and those which were not normally distributed were transformed using SAS programme (SAS Institute Inc., 2002). Weighted plot emissions were tested against the control plot within each site and year. We used the confidence intervals for the difference of means at a $95 \%$ confidence level, which were calculated by the parametrical bootstrap using the statistical package $R$ ( $R$ Development Core Team, 2005). Pairs of locations within one plot were tested against each other and each location was tested against the weighted mean emission of the control plot within each year using the Mann-Whitney rang sum test.

Moisture contents in 2002 were measured as gravimetrically water contents and in 2004 they were calculated using van Genuchten (1980) parameters, obtained by least mean square method of water retention curves $(\alpha=0.008744 ; n=1.329 ; \Theta=0.5136)$, with matric potential derived from tensiometer values. Data concerning soil temper- 
ature, water filled pore space (WFPS), mineral nitrogen compounds, total nitrogen and total carbon were examined for normal distribution and if possible they were transformed to normal distribution. Normal distributed and homoscedasticity data were tested parametrically, otherwise a non- parametric multiple range test was performed, both on a significance level of $95 \%$.

\subsection{Results}

\subsubsection{Site characteristics}

The years when the investigations were carried out were characterized by different meteorological parameters. Lower air temperature in the year 2004 compared to 2002 (Table 2-1) has resulted in slightly lower soil temperatures under vegetation (Table 2-3). Harvesting increased the soil temperature up to $2.3^{\circ} \mathrm{C}$ at the clear cut plot compared to the control plot in year 2004 while a minor effect was observed at the selected harvesting plot. Clear cut plot showed distinct seasonal pattern with higher soil temperatures in summer and lower in autumn (Fig. 2-1).

Table 2-3: $\quad$ Mean soil temperatures $\left({ }^{\circ} \mathrm{C}, \mathrm{n}=10\right.$ ) and water filled pore space (WFPS $\%, n=7$ in 2002 and $n=16$ in 2004) at $5 \mathrm{~cm}$ mineral soil depth for the periods June to November at the years 2002 and 2004.

\begin{tabular}{|c|c|c|c|c|c|}
\hline \multirow[t]{2}{*}{ Plot } & \multirow[t]{2}{*}{ Location } & \multicolumn{2}{|c|}{ mean soil temperatures } & \multicolumn{2}{|c|}{ mean WFPS } \\
\hline & & 2002 & 2004 & 2002 & 2004 \\
\hline \multicolumn{2}{|c|}{ control plot } & 12.1 & 11.1 & 58 & 55 \\
\hline & nearby trunks & - & - & - & 53 \\
\hline & between trunks & $s-$ & - & - & 58 \\
\hline clear & plot & 12.0 & 12.4 & 53 & 70 \\
\hline & undisturbed & - & - & - & $68^{\circ}-x-1$ \\
\hline & disturbed & - & - & - & $85^{\circ}$ \\
\hline selec & harvesting & 12.1 & 10.8 & 58 & 61 \\
\hline & stump & - & - & - & $69^{\circ}$ \\
\hline & crown & - & - & - & $53^{2}$ \\
\hline
\end{tabular}

${ }^{a}$ : indicates significant differences compared to the control plot within each year $(p=0.05)$

The year 2004 was slightly dryer but did not result in pronounced differences of water filled pore space at control plot at Otterbach site. Effects of harvesting resulted in higher water filled pore space at the clear cut plot and in stump vicinity at the selected harvesting plot (Table 2-3). Clear cut harvesting increased the precipitation reaching the forest floor by about $30 \%$.

Table 2-4: $\quad$ Mean values of extractable ammonium, nitrate, and total $\mathrm{N}$ contents $\left(\mathrm{mg} \mathrm{kg}^{-1}\right.$, $\mathrm{n}=27$ ) and standard deviations (sd) in 0-10 cm mineral soil depth in growing season 2004.

\begin{tabular}{lccccccccc}
\hline Plot & \multicolumn{2}{c}{$\mathrm{NH}_{4}^{+}$} & \multicolumn{2}{c}{$\mathrm{NO}_{3}^{-}$} & \multicolumn{2}{c}{$\mathrm{NH}_{4}^{+}+\mathrm{NO}_{3}^{-}$} & \multicolumn{2}{c}{$\mathrm{N}$} \\
& - mean & sd & mean & sd & mean & sd & mean & sd \\
\hline control plot & 2.1 & 0.8 & 1.3 & 0.9 & 2.8 & 1.7 & 11.3 & 2.0 \\
clear cut plot & 2.6 & 1.6 & 3.4 a 2.1 & 5.9 a & 2.9 & 12.8 & 4.1 \\
selected harvesting plot & 2.8 & 2.1 & 3.7 a & 2.2 & 6.1 a & 3.4 & 14.3 & a & 4.5 \\
\hline
\end{tabular}

a: indicate significant differences to the control plot within the site 
Harvesting increased extractable nitrogen concentration with higher values of nitrate (Tab. 2-4).

The compacted layer under the silt cover was located between 52 and $75 \mathrm{~cm}$ depth as indicated by penetrometer measurements. Since the compacted layer was associated with the weathered sandstone layer, the penetrometer values indicated the variability of the thickness of the loess layer on the weathered sandstone.
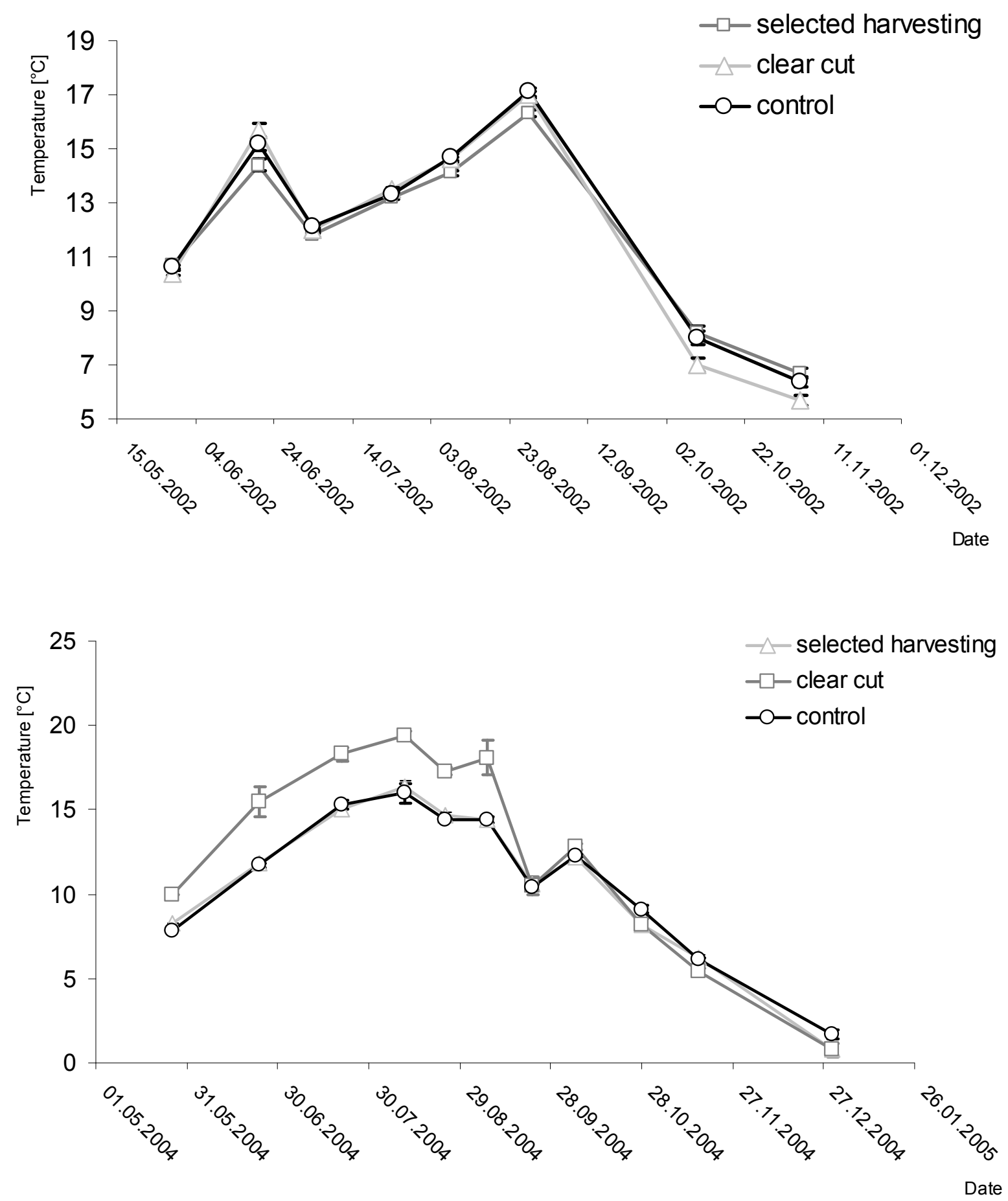

Figure 2-1: Soil temperatures and their standard deviations before harvesting in 2002 (above) and after harvesting in 2004 (bottom), divided in control plot, selected harvesting plot and clear cut plot. 


\subsubsection{Nitrous oxide emissions}

The site showed low $\mathrm{N}_{2} \mathrm{O}$ emissions, with rates up to $20 \mu \mathrm{g} \mathrm{N} \mathrm{N}_{2} \mathrm{O}-\mathrm{N} \mathrm{m}^{-2} \mathrm{~h}^{-1}$ in summer and about $4 \mu \mathrm{g} \mathrm{N} \mathrm{N}_{2} \mathrm{O}-\mathrm{N} \mathrm{m}^{-2} \mathrm{~h}^{-1}$ in autumn in 2002 (Fig. 2-2). The plot emissions did not differ statistically from each other prior to harvesting (Table 2-5). Assuming a contribution of $50 \%$ of both locations to the total area, the total emission amounted to 12, 21 and $29 \mathrm{mg} \mathrm{N} \mathrm{m}^{-2} 158$ days $^{-1}$ (control, clear cut and selected harvesting plots, respectively). Between trunk and trunk vicinity locations did not differ statistically at one of the three plots.
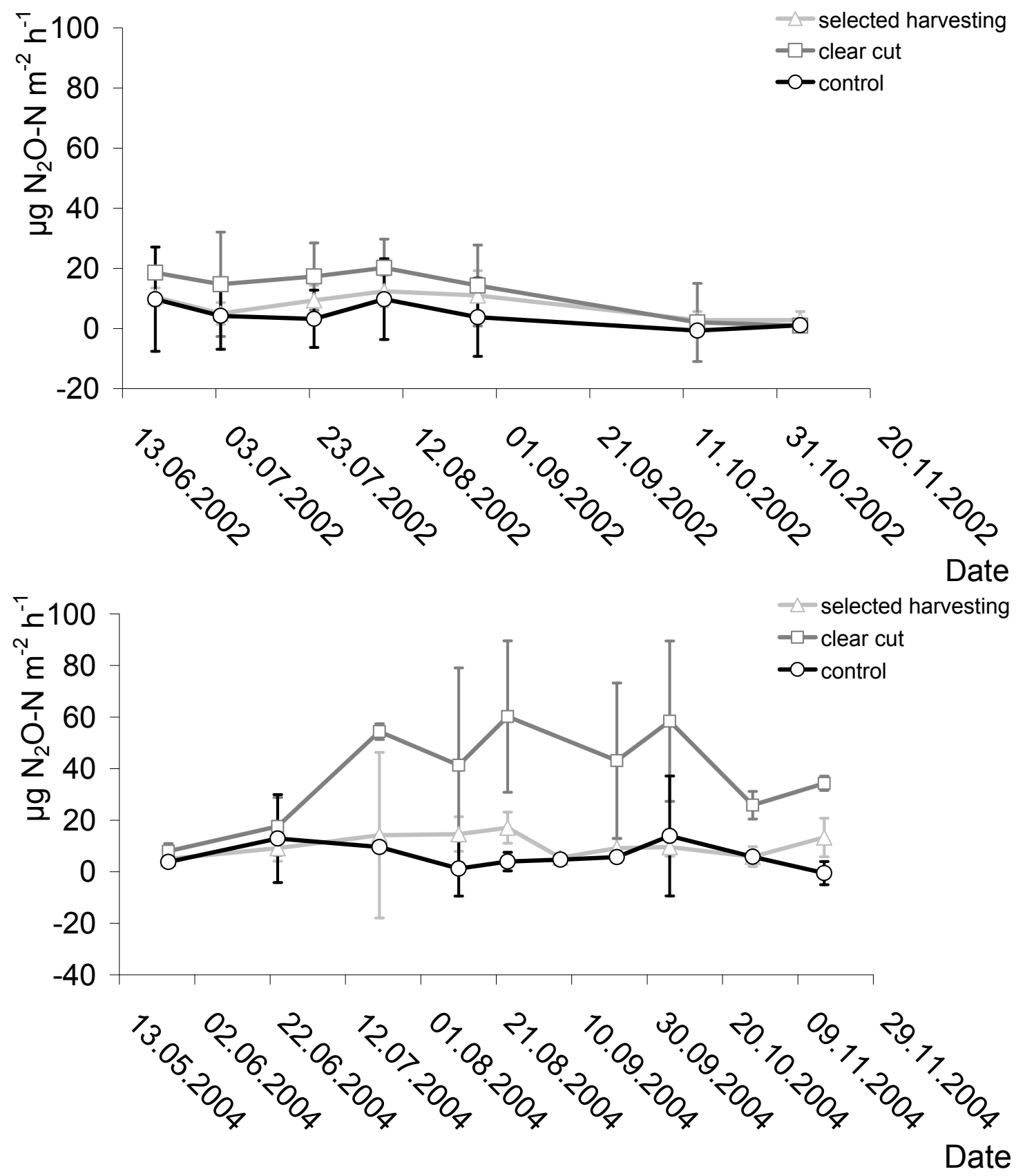

Figure 2-2: $\quad \mathrm{N}_{2} \mathrm{O}-\mathrm{N}$ emission and standard deviations before harvesting in 2002 (above) and after harvesting in 2004 (bottom) divided in control plot, selected harvesting plot and clear cut plot (for each plot $n=10$ ). 
Table 2-5: $\quad \mathrm{N}_{2} \mathrm{O}$ emissions $\left(\mathrm{mg} \mathrm{N} \mathrm{m}^{-2}\right.$ ) for a 158 days period for treatments at Otterbach between 21st June and 26th November for the years 2002 and 2004. Given are cumulated and weighted means, minimum $(\min )$ and maximum $(\max )$ of a $95 \%$ confidence interval for the control, clear cut and selected harvesting plots $(n=10)$ and the locations (nearby trunk, between trunk, undisturbed and disturbed organic layers, skidding trail, under crown and next to a stump, $n=5$ ). Numbers in parenthesis behind the locations refer to percentage of the locations surface to the plot area.

\begin{tabular}{|c|c|c|c|c|c|c|c|}
\hline \multirow[t]{2}{*}{ Plot } & \multirow[t]{2}{*}{ Location } & \multicolumn{2}{|c|}{2002} & \multicolumn{2}{|c|}{$\mathrm{mg} \mathrm{N}_{2} \mathrm{O}-\mathrm{N} \mathrm{m}^{-2} 158 \mathrm{~d}^{-1}$} & \multicolumn{2}{|l|}{2004} \\
\hline & & mean & $\min$ & $\max$ & mean & $\min$ & $\max$ \\
\hline \multirow[t]{3}{*}{ control } & weighted mean & 12 & 1 & 22 & 23 & 20 & 26 \\
\hline & nearby trunk (50) & 10 & 1 & 20 & 24 & 20 & 29 \\
\hline & between trunks (50) & 13 & -9 & 30 & 22 & 14 & 25 \\
\hline \multicolumn{8}{|l|}{ clear cut } \\
\hline \multirow[t]{3}{*}{ before cutting } & weighted mean & 21 & 14 & 30 & & & \\
\hline & nearby trunk (50) & 20 & 12 & 32 & & & \\
\hline & between trunks (50) & 22 & 9 & 37 & & & \\
\hline \multirow[t]{4}{*}{ after cutting } & weighted mean & & & & 111 & 79 & $153^{a}$ \\
\hline & undisturbed (70) & & & & 78 & 45 & $126^{a}$ \\
\hline & disturbed (10) & & & & 78 & 54 & $181^{a}$ \\
\hline & skidding trail (20) & & & & 235 & 133 & $382^{a}$ \\
\hline \multicolumn{8}{|c|}{ selected harvesting } \\
\hline \multirow{3}{*}{ before cutting } & weighted mean & 29 & 19 & 42 & & & \\
\hline & nearby trunk (50) & 16 & 4 & 38 & & & \\
\hline & between trunks (50) & 43 & 24 & $56^{a}$ & & & \\
\hline \multirow[t]{3}{*}{ after cutting } & weighted mean & & & & 42 & 31 & $53^{a}$ \\
\hline & crown $(72)$ & & & & 41 & 28 & $52^{a}$ \\
\hline & stump (28) & & & & 46 & 29 & $88^{a}$ \\
\hline
\end{tabular}

${ }^{a}$ : indicate significant differences of the weighted mean plot emission or of a location to the control plot of the site within one year $(p<0.05)$

The $\mathrm{N}_{2} \mathrm{O}$ emissions at the control plot in 2004 were about two fold higher (23 $\mathrm{mg}$ $\mathrm{N}_{2} \mathrm{O}-\mathrm{N} \mathrm{m}^{-2} 158$ days $\left.^{-1}\right)$ than the rates in 2002 and did not follow a distinct seasonal pattern (Fig. 2-2). Locations nearby and between the trees showed similar rates.

After clear cut harvesting, $\mathrm{N}_{2} \mathrm{O}$ emissions followed a high temporal variation and significantly increased at the undisturbed, disturbed and the skidding trail locations. At the undisturbed locations the harvesting effect led to a significant increase between 19 and $106 \mathrm{mg} \mathrm{N}_{2} \mathrm{O}-\mathrm{N} \mathrm{m}^{-2} 158$ days $^{-1}$. Mean emissions at undisturbed and disturbed locations were of the same magnitude. At the skidding trails three times higher $\mathrm{N}_{2} \mathrm{O}$ rates were measured ( $235 \mathrm{mg} \mathrm{N}_{2} \mathrm{O}-\mathrm{N} \mathrm{m}^{-2} 158$ days $^{-1}$ ) than on the non-skidding areas (78 $\mathrm{mg} \mathrm{N} \mathrm{m}^{-2} 158$ days-1, Table 2-5). Despite their small surface area of $20 \%$, the skidding trails contributed with $30 \%$ to the total plot emission $\left(111 \mathrm{mg} \mathrm{N}_{2} \mathrm{O}-\mathrm{N} \mathrm{m}^{-2}\right.$ 158 days $^{-1}$ ).

At the selected harvesting plot $\mathrm{N}_{2} \mathrm{O}$ emissions significantly increased. Both locations (close to stump and under crown) showed significant increase compared to the control plot. The $\mathrm{N}_{2} \mathrm{O}$ rates observed under crown (41 $\mathrm{mg} \mathrm{N}_{2} \mathrm{O}-\mathrm{N} \mathrm{m}^{-2} 158$ days $^{-1}$ ) and close to stump locations ( $46 \mathrm{mg} \mathrm{N}_{2} \mathrm{O}-\mathrm{N} \mathrm{m}^{-2} 158$ days $^{-1}$ ) were similar (Table 2-5) and induced two times higher total emission rates of $42 \mathrm{mg} \mathrm{N}_{2} \mathrm{O}-\mathrm{N} \mathrm{m}^{-2} 158$ days $^{-1}$ of the selected harvesting treatment compared to the control plot.

\subsubsection{Methane uptake}


The site was a sink for $\mathrm{CH}_{4}$, prior to harvesting. Temporal dynamic and level of $\mathrm{CH}_{4}$ emission were similar at all the three treatment plots (Fig. 2-3) and has resulted in similar uptake rates between -98 and $-99 \mathrm{mg} \mathrm{CH}_{4}-\mathrm{C} \mathrm{m}^{-2}$ in 158 days (Table 2-6) in 2002. $\mathrm{CH}_{4}$ uptake - analogue to emissions but expressed in positive values - at the control plot in the year 2004 was higher and amounted to a weighted mean value which was about 1.7 fold higher than that measured in 2002. No significant differences in methane uptake values were found between and close to trunk locations.
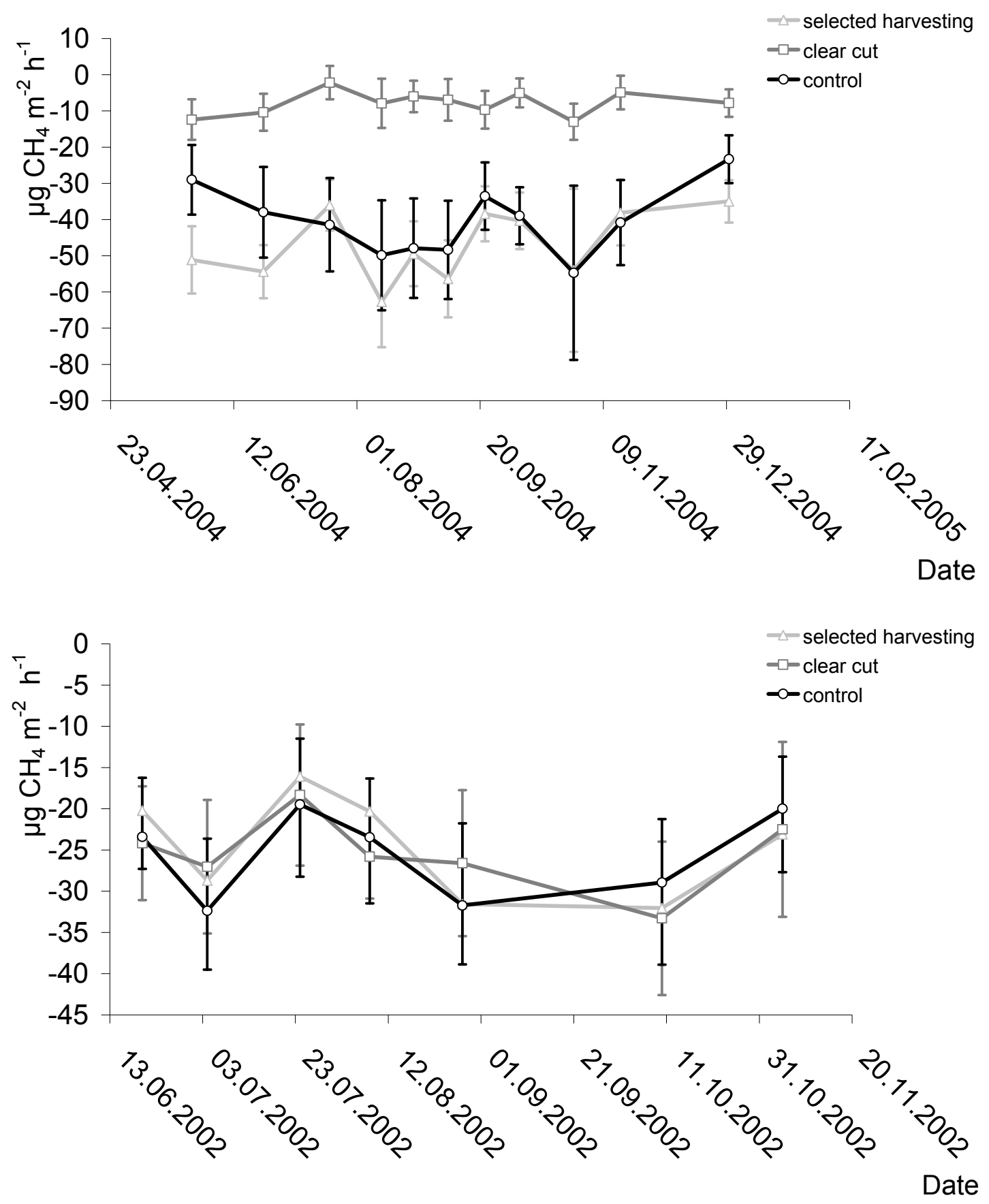

Figure 2-3: $\quad \mathrm{CH}_{4}-\mathrm{C}$ emissions and standard deviations before harvesting in 2002 (above) and after harvesting in 2004 (bottom) divided in control plot, selected harvesting plot and clear cut plot (for each plot $n=10$ ). 
Table 2-6: Methane emissions $\left(\mathrm{mg} \mathrm{CH}_{4}-\mathrm{C} \mathrm{m} \mathrm{m}^{-2}\right.$ ) for a 158 days period for treatments at Otterbach between 21st June and 26th November for the years 2002 and 2004. Given are cumulated and weighted means, minimum $(\min )$ and maximum $(\max )$ of a $95 \%$ confidence interval for the control, clear cut and selected harvesting plots $(n=10)$ and the locations (nearby trunk, between trunk, undisturbed and disturbed organic layers, skidding trail, under crown and next to a stump, $n=5$ ). Numbers in parenthesis behind the locations refer to percentage of the locations surface to the plot area

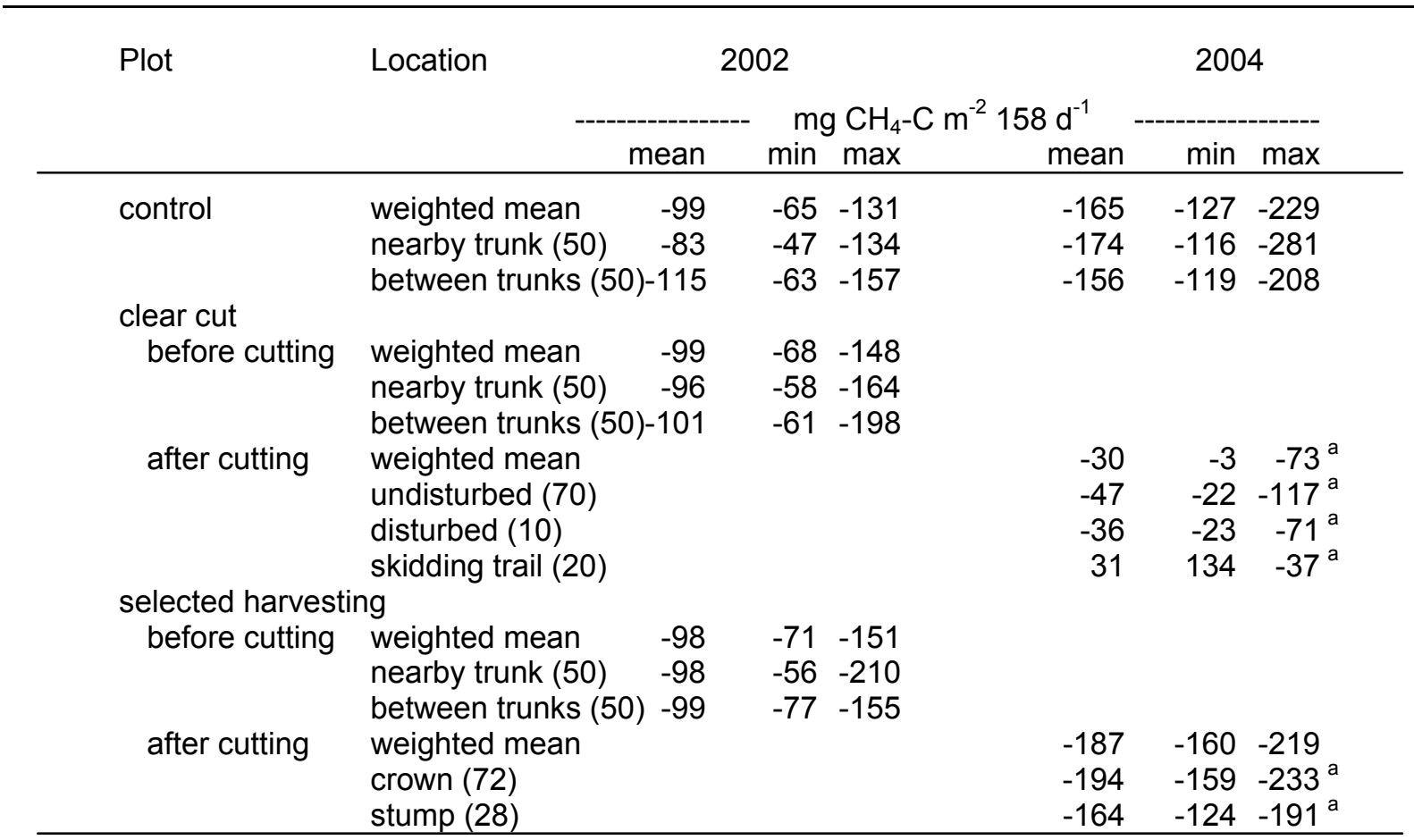

${ }^{a}$ : indicate significant differences of the weighted mean plot emission or of a location to the control plot of the site within one year $(p<0.05)$

Clear cut harvesting significantly reduced the total $\mathrm{CH}_{4}$ uptake to $30 \mathrm{mg} \mathrm{CH}_{4}-\mathrm{C} \mathrm{m}^{-2} 158$ days $^{-1}$ as compared to $165 \mathrm{mg} \mathrm{CH}_{4}-\mathrm{C} \mathrm{m}^{-2} 158$ days $^{-1}$ at the control plot. The oxidation rates did not reveal any temporal pattern (Fig. 2-3). The skidding trails were a source of $\mathrm{CH}_{4}\left(31 \mathrm{mg} \mathrm{CH}_{4}-\mathrm{C} \mathrm{m}^{-2} 158\right.$ days $\left.{ }^{-1}\right)$ in contrast to the disturbed and undisturbed locations where atmospheric $\mathrm{CH}_{4}$ was oxidized in the soil (36 and $47 \mathrm{mg} \mathrm{CH}_{4}-\mathrm{C} \mathrm{m}^{-2} 158$ days $^{-1}$ ). However, the differences between these three locations were not statistically significant (Table 2-6). Methane uptake rates after selected harvesting were the highest observed in this study (up to $63 \mu \mathrm{g} \mathrm{CH}_{4}-\mathrm{C} \mathrm{m}^{-2} \mathrm{~h}^{-1}$ ) but total uptake for the plot (187 $\mathrm{mg} \mathrm{CH}_{4}-\mathrm{C} \mathrm{m}^{-2} 158$ days ${ }^{-1}$ ) was statistically not significant when compared to the rates observed at the control plot (Table 2-6).

\subsection{Discussion}

\subsubsection{Nitrous oxide}

The recent variations of environmental parameters were reflected by the nitrous oxide emission. Interannual variation resulted in a doubling of the emission at the control plot between 2002 and 2004, although the climatological parameters precipitation and temperature were of similar magnitudes during growing season in both years. The increase by interannual variation was smaller than the site variance, 
which was statistically not significant. Regarding to other key parameters like soil texture, soil moisture, soil temperature and nitrogen concentration at mineral soil, the plots were homogenous, so the changes in $\mathrm{N}_{2} \mathrm{O}$ emission following harvesting are reliable to the emissions of the control plot in 2004. The site is a small emitter for $\mathrm{N}_{2} \mathrm{O}$ in both years and the seasonal pattern is conforming to the class of background emitters in the mind of Brumme et al. (1999). Comparison to studies of stratified soils above periglacial deposits shows similar magnitudes of emission. Studies of Lamers (2007) and Jungkunst (2004) along a catena on soil above periglacial slope deposits in the Black Forest observed a water-logged soil layer between 0 and $60 \mathrm{~cm}$ depth. They observed low and non-seasonal average $\mathrm{N}_{2} \mathrm{O}$-fluxes of $<9.0 \pm 9.4 \mu \mathrm{g} \mathrm{N} \mathrm{N}_{2} \mathrm{O}-\mathrm{N} \mathrm{m}^{-2}$ $\mathrm{h}^{-1}$ along a catena which included soil types of Cambisols at the hill, to Gleysols and Histosols at the slope.

Investigations of different locations within the plots showed tendencies of lower $\mathrm{N}_{2} \mathrm{O}$ emissions near trunks and higher emissions between trunks. Higher mean water contents between trunks (Table 2-3) may result from increased throughfall with distance from the stem (Johnson, 1990) and may have raised $\mathrm{N}_{2} \mathrm{O}$ emissions between the trunks. This and the radial decline of root density away from the stem may lead to decreasing water tensions as observed by Türk (1992). However, the effect showed for only one plot significant results on the $\mathrm{N}_{2} \mathrm{O}$ emissions, so that the general assumption of a straight stratification is not supported. Short term variations in space and time may overlay such effects at background emission soils. Also von Arnold et al. (2005) found an insignificant increase of water content and $\mathrm{N}_{2} \mathrm{O}$ emission with distance to stem at a Swedish spruce site. In contrast Butterbach-Bahl et al. (2002) found higher water tensions and congruently lower emissions at the interstem areas on a German spruce forest.

\subsubsection{Selected harvesting}

Selected harvesting significantly increased the $\mathrm{N}_{2} \mathrm{O}$ emissions compared to the control plot. This effect was not only driven by the locations affected by harvesting, but by the locations under the crown of surrounding trees. More than two third of the plot area were identified as locations under crown. The stump locations had slightly higher mean emissions, but with respect to the small proportion of stump locations to the plot area this small difference could not result in substantial changes of the whole plot emission. Lost interception, a lack in water and $\mathrm{N}$ uptake by roots (Klinck, 2009; Marthews et al. 2008), indicated an open N-cycle. High $\mathrm{N}$ availability and high water filled pore space explain the increase in $\mathrm{N}_{2} \mathrm{O}$ emissions close to harvested trees. Both, an increase of soil moisture content and mineralization rates (Bauhus et al., 1996) were also found after the creation of forestry gaps in a beech forest at the Solling area and significantly increased the $\mathrm{N}_{2} \mathrm{O}$ emissions within the gaps (Brumme, 1995). On the other hand Sharenbroch et al (2007) found higher microbial biomass $\mathrm{N}$ in distance 
to treefall gaps in northern hardwood-hemlock forests and significantly less exchangeable base cations. From our data high $\mathrm{N}$ availability is indicated for the whole plot and therefore increased microbial activity may be also found at the locations in distance to the centre of the gap.

Likewise to the undisturbed forest stand a consequent horizontal stratification for $\mathrm{N}_{2} \mathrm{O}$ emissions could not be acquired. Rather the complexity of the system is expressed by higher variance. This appears to be a result of the $\mathrm{N}$ concentrations at the whole plot, which were highest within this study, and variance due to the impact of the temporally highly variable meteorological parameters precipitation and temperature on the stump locations.

\subsubsection{Clear cut harvesting}

Clear cut harvesting substantially increased the $\mathrm{N}_{2} \mathrm{O}$ emissions. At the non-frequented area, which covered $80 \%$ of the clear cut, the emissions increased by $240 \%$ when compared to the control plot. Increased water filled pore space, soil temperature and increased availability of mineral nitrogen after harvesting has increased the $\mathrm{N}_{2} \mathrm{O}$ emissions. The difference in water filled pore space between disturbed and undisturbed locations of the non-frequented area support the assumption of specific spatial unities related to harvesting, what did not lead to coercible different $\mathrm{N}_{2} \mathrm{O}$ emissions, but apparently led to higher variations. This supports the finding that in coniferous forests the organic layer is not the primary source for $\mathrm{N}_{2} \mathrm{O}$ in contrast to moder type humus soils of deciduous forests (Brumme et al. 1999; Dong et al., 1998), which may explain that disturbances of the organic layer during harvesting did not change the $\mathrm{N}_{2} \mathrm{O}$ emission.

The $\mathrm{N}_{2} \mathrm{O}$ emissions of the skidding trails differ strongly from the non-frequented area. The ten times higher $\mathrm{N}_{2} \mathrm{O}$ emissions from the skidding trails compared to the control plot at Otterbach site were presumably influenced by an oxygen deficit within the layer of organic debris. High emission of $\mathrm{N}_{2} \mathrm{O}$ after compaction and mixing of forest soil by wheel traffic during harvesting was also observed by Teepe et al. (2004) and Keller et al. (2005), and was explained by reduced macropore volume and increased water filled pore space. However, despite the contrasting fluxes of the frequented and non-frequented areas the effect of the skidding trail on the weighted mean value for the plot is moderate due to its low fraction of the total area. These results demonstrate the importance of skidding trails as a potentially significant source of $\mathrm{N}_{2} \mathrm{O}$ at harvested areas.

Zerva and Mencuccini (2005) presented emissions data of an untreated and a clear felled Sitka spruce plantation on a gley soil in Northeast England. The emissions of $\mathrm{N}_{2} \mathrm{O}$ at the control plot amounted to $230 \mu \mathrm{g} \mathrm{N} \mathrm{N}_{2} \mathrm{O}-\mathrm{N} \mathrm{m}^{-2} \mathrm{~d}^{-1}$ and increased to $590 \mu \mathrm{g} \mathrm{N} \mathrm{O}_{2} \mathrm{O} \mathrm{N} \mathrm{m}^{-2} \mathrm{~d}^{-1}$ after clearfelling over a period of 10 months from March to December in the year after harvesting. Almost consistently high $\mathrm{N}_{2} \mathrm{O}$ emissions were 
found at two clear cut Norway spruce stands on nutrient rich drained peatlands in southern Finland. The averaged $\mathrm{N}_{2} \mathrm{O}$ emissions after clear cutting amounted 945 and $246 \mu \mathrm{g} \mathrm{N} \mathrm{N}_{2} \mathrm{O}-\mathrm{N} \mathrm{m}^{-2} \mathrm{~d}^{-1}$ for the first two growing seasons after cutting, respectively (Huttunen et al., 2003). Compared to our study with values between 386 and $702 \mu \mathrm{g} \mathrm{N}_{2} \mathrm{O}-\mathrm{N} \mathrm{m}^{-2} \mathrm{~d}^{-1}$ at the clear cut site, the values reported in literature were of similar order. However, a clear cut of a 24 year old Pinus radiata plantation in New Zealand on a highly porous and free drained soil did not change the $\mathrm{N}_{2} \mathrm{O}$ emissions one year after harvesting (Tate et al., 2006). This study stressed the importance of failing transpiration and interception after harvesting for high $\mathrm{N}_{2} \mathrm{O}$ emissions at sites with high water filled pore space while sites with porous soils and low water filled pore space might not be affected by harvesting. In the study of Tate et al. (2006) an experiment with no-slash, normal slash and high slash additions did not show statistically significant differences. The slash was added to soil chambers and was not compacted in contrast to our study at Solling site, where the slash was condensed by harvesters and significantly changed the trace gas emissions.

\subsubsection{Methane}

The mean $\mathrm{CH}_{4}$ uptake rates before harvesting were very homogenous and from statistical base stratifications into locations nearby and between trunks were not supported. There is a tendency for higher uptakes between trunks, but with the design used in this study this hypothesis was not provable. The oxidation rates of methane were in the range of $\mathrm{CH}_{4}$ oxidation values as reported by Smith et al. (2000) for temperate forests.

Interannual variation was controlled by precipitation rates affecting the soil water content of deeper layers and the aeration of the topsoil. $\mathrm{CH}_{4}$ can be built in anoxic layers of ground- or stagnation water when degradable carbon is available. In overlain ventilated soil it can be consumed (Segers, 1998). The lower precipitation rates in 2004 caused an increase of the uptake of $\mathrm{CH}_{4}$ by factor 1.7, as compared to 2002. This is in accordance with the findings of Fiedler et al. (2008) after the 2003 summer drought at a endoskeletic Cambisol. Stagnation water in $60 \mathrm{~cm}$ depth was assumed to be the source of $\mathrm{CH}_{4}$ in years with high precipitation and low transpiration rates. Occurrence of stagnation water at Otterbach site is indicated by well observations. The $\mathrm{CH}_{4}$ born in the water saturated zone is consumed in aerated overlain soil layers. So in drier years the proportion of oxidised atmospheric $\mathrm{CH}_{4}$ can increase. This may explain why the $\mathrm{CH}_{4}$ uptake rates are decoupled from the surfaces mater and energy patterns in stratified soils with connection to anoxic layers in temperate forest. 


\subsubsection{Selected harvesting}

Selected harvesting showed no significant difference in $\mathrm{CH}_{4}$ uptake compared to the control plot. Higher water filled pore space in stump vicinity indicated an effect of selected harvesting and showed a tendency for lower uptake rates at this location which were not significant. A thinning experiment of Dannemann (2007) indicated significantly lower $\mathrm{CH}_{4}$ uptake rates at the north east facing slope. However, this effect was presumably not caused by thinning since the direct effect of harvesting on methane oxidation at vicinity of trees was not studied.

\subsubsection{Clear cut harvesting}

Clear cutting had a strong effect on the $\mathrm{CH}_{4}$ uptake and significantly decreased the $\mathrm{CH}_{4}$ uptake at locations not affected by trafficking. This effect was due to reduced $\mathrm{CH}_{4}$ diffusion caused by high water filled pore space after harvesting (Table 2-3). Locations with disturbed and undisturbed surface organic layer showed similar $\mathrm{CH}_{4}$ uptake rates. This result is in contrast to other findings where surface organic layers acted as effective diffusion barriers (Bradford et al., 2001; Saari et al, 1997; Adamsen and King, 1993; Borken and Brumme, 1997). Similar uptake rates at the disturbed and undisturbed locations might be explained by any compaction while the surface organic layers were disturbed. In contrast to the non-frequented area the $\mathrm{CH}_{4}$ fluxes from the skidding trails indicated that such areas formed a net source of $\mathrm{CH}_{4}$ after organic debris was accumulated and compacted by trafficking. Despite the low contribution of the skidding trails of only $20 \%$ to the total area, the emission from the skidding trail had an important force when considering the confidence interval, where the whole plot is moved in close proximity to an overall zero uptake. Accumulation of logging debris on skidding trails is conduced as a step to prevent any compaction of soils by trafficking but, as indicated by our study, such a procedure will significantly change trace gas fluxes between soil and atmosphere. Reduced $\mathrm{CH}_{4}$ uptake after compaction by tractor traffic was observed at arable (Hansen et al, 1993; Ruser et al., 1998) and forest skidding trails (Teepe et al, 2004).

Laboratory experiments with controlled, constant temperatures on soil cores taken before and after clear cutting of a Norway spruce stand showed a decrease in uptake rates of 35-60 \% in dependence on the season the cores were taken (Kähkönen et al., 2002). A similar study on soil probes of cleared monocultures of beech and larch reported a reduction of $40-60 \%$ (Bradford et al., 2001) and was interpreted due to a drop in $\mathrm{pH}$ and an increase in soil compaction. The reduction found in this field-study considering the skidding trail offered a decrease of $80 \%$ related to the control plot. Clear felling of a Sitka spruce stand in the UK turned the site from a small sink to a source with large variation of $0-17 \mathrm{mg} \mathrm{CH}_{4} \mathrm{~m}^{-2} \mathrm{~d}^{-1}$ (Zerva and Mencuccini, 2005). This Sitka spruce site had a high water table $(12-25 \mathrm{~cm})$ and indicated that a possible 
$\mathrm{CH}_{4}$ uptake of the surface soil was masked by a methane production in deeper layers due to the displacement of organic compounds after clear cutting. Redistribution of organic components was observed in previous study (Henriksen and Kirkhusmo, 2000) and supports the assumption of brief vertical relationships of soil water chemistry and $\mathrm{CH}_{4}$ emission. Also for the skidding trails, where the top layer was compacted and mixed with organic matter, this can be an explanation for the finding of $\mathrm{CH}_{4}$ release to the atmosphere. Reduction of compaction and the avoidance of mixing the topsoil with organic compounds proffer high potential in reduction $\mathrm{CH}_{4}$ emissions after clear cut.

\subsection{Conclusions}

Forest harvesting increased the variance through disturbance of the surface organic layer and through formation of skidding trails it increased spatial heterogeneity at clear cut. This heterogeneity is an important factor which needs to be considered while evaluating the effects on emissions from a whole plot basis. Despite the small fraction of the total area occupied by skidding trails, high compaction on this area will increase $\mathrm{CH}_{4}$ and $\mathrm{N}_{2} \mathrm{O}$ emissions. Soil moisture content was the most important parameter for this increase in $\mathrm{N}_{2} \mathrm{O}$ and a decrease in $\mathrm{CH}_{4}$ uptake. Impeded drainage by the compacted subsurface layer increased the effects of harvesting on trace gas fluxes. This situation is very common for some regions in Europe and may have a stronger effect on trace gas fluxes than harvesting. Even selected harvesting increased the variance by altering the input-output balance of nutrients and water close to the area where trees were felled. The initial effects on $\mathrm{CH}_{4}$ and $\mathrm{N}_{2} \mathrm{O}$ fluxes were small on a plot basis. Different intensity of harvesting led to different impact on $\mathrm{N}_{2} \mathrm{O}$ emission but for $\mathrm{CH}_{4}$ emission only the clear cut harvesting had significant impact on emission. At clear cut sites reduction of compaction and mixing of topsoil with organic matter offers potential for decreasing soil born trace gas emissions.

\section{Acknowledgements}

This research is part of the project BE 713 / 27-1 and was supported by the 'Deutsche Forschungsgemeinschaft' (DFG). We would like to thank Partap K. Khanna for his comments on the manuscript. 


\subsection{References}

Adamsen, A.P.S, and G.M. King. 1993. Methane consumption in temperate and subarctic forest soils: Rates, vertical zonation, and responses to water and nitrogen. Appl. Environ. Microbiol. 59, 485-489.

Bäckman, J.S.K., A.K. Klemedtsson, L. Klemedtsson, and P.-E. Lindgren. 2004. Clear-cutting affects the ammonia-oxidising community differently in limed and non-limed coniferous forest soils. Biol. Fertili. Soils 40, 260-267.

Bauhus J. 1996. C and $\mathrm{N}$ mineralization in an acid forest soil along a gap-stand gradient. Soil Biol. Biochem. Vol. 28, No. 7, 923-93.

Barg, A.K., and R.L. Edmonds. 1999. Influence of partial cutting on site microclimate, soil nitrogen dynamics, and microbial biomass in Douglas-fir stands in western Washington. Can. J. For. Res. (29), 705-713.

Berger, A.L., K.J. Puetmann, and G.E. Host. 2004. Harvesting impacts on soil and understory vegetation: the influence of season of harvest and within-site disturbance patterns on clear-cut aspen stands in Minnesota. Can. J. For. Res. (34), 2159-2168.

Borchert, H., and R. Graf. 1988. Zum Vergleich von Penetrometermessungen, durchgeführt bei unterschiedlichem Wassergehalt. Zeitschrift f. Pflanzener. u. Bodenkunde, 151, 69-71.

Borken, W., and R. Brumme. 1997. Liming practice in temperate forest ecosystems and the effects on $\mathrm{CO}_{2}, \mathrm{~N}_{2} \mathrm{O}$ and $\mathrm{CH}_{4}$ fluxes. Soil Use and Management 13, 251-257.

Bouwman, A.F. 1990. Soils and the greenhouse effect. John Wiley \& Sons, New York.

Bradford, M.A., P. Ineson, P.A. Wookey, and H.M. Lappin-Scott. 2001. Role of $\mathrm{CH}_{4}$ oxidation, production and transport in forest soil $\mathrm{CH}_{4}$ flux. Soil Biol. Biochem. 33, 1625-1631.

Brumme, R., W. Borken and S. Finke. 1999. Hierarchical control on nitrous oxide emission in forest ecosystems, Glob. Biogeochem. Cycles 13, 1137-1148

Brumme, R. 1995. Mechanisms for Carbon and nutrient release and retention in beech forest gaps, 3 . Environmental regulation of soil respiration and nitrous oxide emission along a microclimatic gradient. Plant Soil 168-169, 593-600.

Butterbach-Bahl, K., A. Rothe, and H. Papen. 2002. Effect of tree distance on $\mathrm{N}_{2} \mathrm{O}$ and $\mathrm{CH}_{4}$-fluxes from soils in temperate forest ecosystems. Plant Soil 240, 91-103.

Crutzen, P.J. 1981. Atmospheric chemical processes of the oxides of nitrogen, including nitrous oxide. In: Denitrification, Nitrification and Atmospheric Nitrous oxide, 17-45, Delwiche, C.C. Wiley New York.

Dannemann, M., R. Gasche, A. Ledebuhr, T. Holst, H. Mayer, and H. Papen. 2007. The effect of forest management on trace gas exchange at the pedosphere-atmosphere interface in beech (Fagus sylvatica L.) forests stocking on calcareous soils. Eur. J. For. Res. 126,331-346.

Dong, Y., D. Scharffe, J.M. Lobert, P.J. Crutzen, and E. Sanhueza. 1998. Fluxes of $\mathrm{CO}_{2}, \mathrm{CH}_{4}$ and $\mathrm{N}_{2} \mathrm{O}$ from a temperate forest soil: the effects of leaves and humus layers. Tellus, 50B, 243-252.

Efron, B., and R. Tibshirani. 1993. An Introduction to the Bootstrap. CRC Press LLC, Boca Raton. 
Fiedler, S., M. Lamers, J. Ingwersen, T. Streck, K. Stahr, and F. Jungkunst. 2008. Impact of the heatwave in 2003 on the summer $\mathrm{CH}_{4}$ budget of a spruce forest with large variation in soil drainage: A four-year comparison (2001-2004). J. Plant. Nutr. Soil Sci. 171, 666-671.

Firestone, M.K., and E.A. Davidson. 1989. Microbial basis of $\mathrm{NO}$ and $\mathrm{N}_{2} \mathrm{O}$ production and consumption in soil. In Andreae, M.O. and D.S. Schimmel (eds) Exchange of Trace gases between terrestrial ecosystems and the atmosphere, 7-21, John Wiley \& Sons, New York.

Friedrich, J. 1992. Räumliche Variation bodenchemischer und -physikalischer Merkmalsgrößen sowie der Wurzelverteilung in Buchen- und Fichtenwaldökosystemen. Berichte des Forschungszenstrums Waldökosysteme d. Univ. Göttingen, Reihe A, Bd. 83.

Gundersen, P., B.R. Andersen, C. Beier, and L. Rasmussen. 1995. Experimental manipulation of water and nutrient input to a Norway spruce plantation at Klosterhede, Denmark 1) Unintended physical and chemical changes by roof experiments. Plant Soil 168/169, 601-611.

Hansen, S., J.E. Maehlum, and J.R. Brakken. 1993. $\mathrm{N}_{2} \mathrm{O}$ and $\mathrm{CH}_{4}$ fluxes in soil influenced by fertilization and tractor traffic. Soil Biol. Biochem. 25,621-630.

Hendrickson, O.Q., and J.B. Robinson. 1984. Effects of roots and litter on mineralization processes in forest soil. Plant Soil (80), 391-405.

Henriksen, A., and L.A. Kirkhusmo. 2000. Effects of clear-cutting of forest on the chemistry of a shallow groundwater aquifer in southern Norway. Hydrol. Earth Syst. Sci. 4 (2), 323-331.

Huttunen J.T., H. Nykänen, P. Martikainen, and M. Nieminen. 2003. Fluxes of nitrous oxide and methane from drained peatlands following forest clear-felling in southern Finland. Plant Soil 255, 457-462.

IPCC, 2007. Climate Change 2007. The scientific basis. Cambridge University Press, London.

Johnson, R.C. 1990. The interception, throughfall and stemflow in a forest in highland Scottland and the comparison with other upland forests in the U.K. J. Hydrol. 118, 281-287.

Jungkunst, H.F., S. Fiedler, and K. Stahr. 2004. $\mathrm{N}_{2} \mathrm{O}$ emissions of a mature Norway spruce (Picea abies) stand in the Black Forest (southwest Germany) as differentiated by the soil pattern. J. Geophys. Res.-Atmospheres, 109 (D7), No. D07302.

Kähkönen, M.A., C. Wittmann, H. Ilvesniemi, C.J. Westman, and M.S. Salkinoja-Salonen. 2002. Mineralization of detritus and oxidation of methane in acid boreal coniferous forest soils: seasonal and vertical distribution and effects of clear-cut. Soil Biol. Biochem. 34, 1191-1200.

Keller, M., R. Varner, J.D. Dias, H. Silva, P. Crill, and R.C. de Oliveira. 2005. Soil-atmosphere exchange of nitrous oxide, nitric oxide, methane, and carbon dioxide in logged and undisturbed forest in the Tapajos National Forest, Brazil. Earth interactions 9, 23.

Klinck, U. 2009. Kohlenstoffvorrat, Nährstoffvorräte und Wasserdynamik nach forstlichen Eingriffen in Fichtenreinbeständen. In Dissertationschrift, unveröffentlicht.

Knittel, H., and H. Stanzel. 1976. Untersuchungen des Bodengefüges mit Penetrometer und Rammsonde. Z. Acker u. Pflanzenbau, 142, 181-193. 
Koch, A.S., and E. Matzner. 1993. Heterogeneity of soil and soil solution chemistry under Norway spruce (Picea abies Karst.) and European beech (Fagus silvatica L.) as influenced by distance from the stem basis. Plant Soil 151: 227-237, 1993.

Kompa, T. 2004 Die Initialphase der Vegetationsentwicklung nach Windwurf in Buchen-Wäldern auf Zechstein- und Buntsandstein-Standorten des südwestlichen Harzvorlandes. Dissertation.

Lamers, M., J. Ingwersen, and T. Streck. 2007. Nitrous oxide emissions from mineral and organic soils of a Norway spruce stand in South-West Germany. Atmos. Environ. 41, 1681-1688.

Lashof, D.A., and D.R. Ahuja. 1990. Relative contribution of greenhouse gas emissions to global warming. Nature 344, 529-531.

Loftfield, N., H. Flessa, J. Augustin, and F. Beese. 1997. Gas chromatographic system for rapid analysis of the atmospheric trace gases methane, carbon dioxide, and nitrous oxide. J. Environ. Qual. 26, 560-564.

Lundgren, B. 1982. Bacteria in a pine forest soil as affected by clear-cutting. Soil Biol. Biochem., 14, 537-542.

Maljanen, M., A. Liikanen, J. Silvola, and P.J. Martikainen. 2003. Nitrous oxide emissions from boreal organic soil under different land-use. Soil Biol. Biochem. 35,689-700.

Marthews T.R., D.F.R.P. Burslem, S.R. Paton, F. Yanyuez, and C.E. Mullins. 2008. Soil drying in a tropical forest: Three distinct environments controlled by gap size. Ecol. Model. 216 (3-4), 369-384.

Moore, A.M. 1986. Temperature and moistre dependence of decomposition rates of hardwood and coniferous leaf litter. Soil Biol. Biochem. 18,4, 427-435.

Ojima A., D.W. Valentine , A.R. Mosier, W.J. Parton, and D.S. Schimel. 1993. Effect of land use change on methane oxidation in temperate forest and grassland soils. Chemosphere 26, 675-685.

Pallent, E. and S.J. Riha. 1991. Surface soils acidification under red pine and Norway spruce. Soil Sci. Soc. Am. J. 54, 1124-1130.

R statistical Package: R Development Core Team, 2005

Ritter, E., L. Dalsgaard, and K.S. Einhorn. 2005. Light, temperature and soil moisture regimes following gap formation in a semi-natural beech-dominated forest in Denmark. Forest Ecol. Managem. 206, 15-33

Ruser, R., H. Flessa, R. Schilling, H. Steindl, and F. Beese. 1998.: Soil compaction and fertilization effects on nitrous oxide and methane fluxes in potato fields. Soil Sci. Soc. America J. 62, 1587-1595.

Saari, A., P.J. Martikainen, A. Ferm, W. Ruuskanen, W. De Boer, S.R. Troelstra, and H.J. Laanbroek. 1997. Methane oxidation in soil profiles of Dutch and Finnish coniferous forests with different soil texture and atmospheric nitrogen deposition. Soil. Biol. Biochem. 29, 1625-1632.

SAS 9.1 SAS Institute Incorporation. 2002.

Schernbroch, B.C., and J.G. Bockheim. 2007. Impacts of forest gaps on soil properties and processes in old growth northern hadwood-hemlock forests. Plant Soil 294, 219-233. 
Schimmel, J.P., and J. Gulledge. 1998. Microbial community structure and global trace gases. Glob. Chang. Biol. 4, 745-758.

Schulte-Bisping H., R. Brumme, and E. Priesack. 2003. Nitrous oxide emission inventory of German forest soils. J. Geophys. Res. 108(D4) 4132, doi: 10.1029/JD002292.

Segers, R. 1998. Methane production and methane consumption: a review of processes underlying wetland methane fluxes. Biogeochem. 41, 23-51.

Seiler, J., and E. Matzner. 1995.Spatial variability of throughfall chemistry and selected soil properties as influenced by stem distance in a mature Norway spruce (Picea abies, Karst.) stand. Plant Soil 176: 139-147, 1995.

Smith, K.A., K.E. Dobbie, B.C. Ball, L.R. Bakken, B.K. Sitaula, S. Hansen, R. Brumme, W. Borken, S. Christensen, A. Prieme, D. Fowler, J.A. McDonald, U. Skiba, L. Klemedtsson, A. KasimirKlemedtsson, A. Degorska, and P. Orlanski. 2000. Oxidation of atmospheric methane in northern European soil, comparison with other ecosystems, and uncertainties in the global terrestrial sink. Glob. Chang. Biol. 6, 791-803.

Tate K.R., D.J. Ross, N.A. Scott, N.J. Rodda, J.A. Townsend, and G.C. Arnold. 2006. Post-harvest patterns of carbon dioxide production, methane uptake and nitrous oxide production in a Pinus radiata D. Don plantation. Forest Ecol. Managem. 228, 40-50

Teepe, R., R. Brumme, F. Beese, and B. Ludwig. 2004. Nitrous oxide emission and methane consumption following compaction of forest soils. Soil Sci. Soc. Am. J. 68, 605-611.

Türk, T. 1992. Die Wasser- und Stoffdynamik in zwei unterschiedlich geschädigten Fichtenstandorten im Fichtelgebirge. Bayreuther bodenkundliche Berichte 22.

van Genuchten, M.T. 1980. A closed-form equation for predicting the hydraulic conductivity of unsaturated soils. Soil Sci. Soc. Am. J. 44, 892-898.

von Arnold, K., M. Ivarsson, M. Öqvist, H. Majdi, R.G. Björk, P. Weslien, and L. Klemedtson. 2005. Can distribution of trees explain variation in nitrous oxide fluxes? Scand. J. For. Res. 20, 481-489.

Welke, S.E., G.D. Hope, and G.A. Hung. 2003. Effects of harvesting on fine root biomass and decomposition in an Engelmann spruce - subalpine fir forest. Can. J. For. Res. 33, 847-853.

Zerva A., and M. Mencuccini. 2005. Short-term effects of clearfelling on soil $\mathrm{CO}_{2}, \mathrm{CH}_{4}$, and $\mathrm{N}_{2} \mathrm{O}$ fluxes in a Sitka spruce plantation. Soil Biol. Biochem. 27,2025-2036. 


\title{
3 Temporal and spatial variations of two-sided edge effects on small clear cuts
}

\author{
D. Fröhlich ${ }^{1}$, U. Klinck ${ }^{2}$ and F. Beese ${ }^{1}$ \\ ${ }^{1}$ Universität Göttingen, Büsgen-Institut, Department for Soil Science of Temperate and Boreal \\ Ecosystems, Büsgenweg 2, 37077 Göttingen, Germany \\ ${ }^{2}$ Nordwestdeutsche Forstliche Versuchsanstalt, Abt. Umweltkontrolle - Grätzelstraße 2 - 37079 \\ Göttingen
}

Key words: soil temperature, edge effect, Norway spruce

Corresponding author: Daniel Fröhlich

\subsection{Abstract}

Openings in forest ecosystems are a common phenomenon due to harvesting, windthrow or pests. Depending on the size of the gap and the height of the surrounding trees the spatial distribution of the energy input, the precipitation and the temperatures in the top soil are affected. As well parts of the surrounding trees are affected by altering microclimatology. The aim of this study was to describe the two-sided edge effects and their variation in time and space, because there is a lag of investigations with a two-sided approach. Therefore transects from the forest interior build by 85 years old and about $35 \mathrm{~m}$ high spruce trees across the tree-base line to the opening of a clear cut were instrumented with soil temperature loggers. The mean soil temperatures of two years and the results of an irradiance-model were interpolated with an empirical function across the tree base-line and applied to the values of the deep forest and clear cut centre. By this function the effects of the direction and the extensions of transition zones were studied and the spatial distribution of the soil temperatures was applied to the $\mathrm{CO}_{2}$ release of the organic layer of spruce forest. The gradients of both the soil temperature and radiation showed dependence on aspect and there was a strong dependence of penetration distance on time and aspect. For example the transition zone of soil temperatures into the forest amounted to $34 \mathrm{~m}$ in May and $59 \mathrm{~m}$ in September at the north-east edge. The furthermost extension of the transition zone reached $94 \mathrm{~m}$ in September across the south-east edge in September and was 0 in December due to no significant differences in soil temperatures between forest interior and clear cut centre. This demonstrates that a opening of only few ha in size is not a homogenous area with respect to ecophysiological parameters and the transition zones, which are different from the centre, are remarkable. This has to be considered when an ecological assessment of clear cuts is planned. 


\subsection{Introduction}

The opening of closed canopies by clearcut harvesting, windthrow (e.g. FischerBruns et al., 2005; Pinto et al., 2007), pests or snow break creates treeless areas of different size surrounded by trees of up to $50 \mathrm{~m}$ height. Depending on the height of these trees and the size of the glade in the stand, the surrounding trees effect the spatial distribution of the abiotic environment like energy input, the precipitation and the deposition of elements (Camargo and Kapos, 1995). Consequently the water and nutrition supply to the young trees, the temperature of the soil, the mineralization rates and decomposer community are not evenly distributed over the whole area. For instance faster decomposition rates of the soil organic matter were found near the edge from edge-to-interior-transects by Didham (1998).

This in mind we have to regard those clearings not as homogeneous areas as mostly done in the past, but as areas which are characterized by more or less smooth physical, chemical and biological gradients from undisturbed stand via forest tree line to the middle of the clearing.

Modifications of the abiotic environment are evident at the interface between forested and cleared areas and integrated reactions of the biota are expected. For instance there are changes in the ecophysiology of plants (Kapos, 1993), the vegetation structure (Lewis, 1998; Sizer and Tanner, 1999) and the abundances of invertebrates (Didham et al. 1999; Carvalho and Vasconcelos, 1999) and birds (Lovejoy, 1986). However the distance in which changes take place within the forest can be short (Rubinstein and Vasconcelos, 2005), but knowledge about penetration distance into the clearing and its variation with time of the year is scarce.

Former investigations of edge effects after clear cutting focus on the penetration distance into the remnant forest (Chen et al., 1993, Chen et al., 1995) with the aim to find the appropriate minimum size of forest patches. On the other hand in some investigations short time steps within the vegetation period are discussed or the focus was on diurnal cycles (Davies-Colley et al., 2000) to highlight physiological relevant extremes.

In contrast the present work the focuses on (i) the two sided effect i.e. the effects in both directions from the tree line, because models require parameters that only can be generated by a two-sided approach (Fonseca and Joner, 2007); (ii) the different aspects to radiation and (iii) mean values of radiation and soil temperature of different periods and years to gain patterns independent from short-term weather conditions. Further, the presented approach has the aim to ease the resource mapping, in this way to contribute to a better understanding of complex interactions at forest edges and to highlight critically the claim of measurements in the middle of small treeless areas to be representative. This may result in optimal silvicultural practices of the special environment of small clearings. 


\subsection{Site, material and methods}

\subsubsection{Site description}

The site studied is embedded in a mature Norway spruce (Picea abies L.) stand. It is located at the Solling area (Otterbach $51^{\circ} 46^{\prime} \mathrm{n}$. Br., $9^{\circ} 27^{\prime}$ ö. L.) $60 \mathrm{~km}$ in the Northwest of Göttingen (Germany). In October 2003 a rectangle area of about $120 \times 120 \mathrm{~m}$ was cleared. The slash was removed from the site, to avoid bark beetle attacks. At this time the surrounding stand was 85 years old. At the north-east edge the adjoining stand was build by oak (Quercus robur, L.) trees. One year after cutting in the north-east corner bracken (Pteridium aquilinum, L.) established as dominating plant cover, in the middle and south west corner grew blackberry and in the northern corner scarce grass vegetation was found.

The experimental site is at an altitude of $310 \mathrm{~m}$ and has a gentle slope to the Northeast $\left(<3^{\circ}\right)$. The mean annual temperature and annual precipitation was $9.5^{\circ} \mathrm{C}$ and $1027 \mathrm{~mm}$ for a three year record (2005-2007) in the middle of the clearing.

The soil has been classified as Dystric Cambisol derived from Triassic sandstone, covered by loess $(60-90 \mathrm{~cm})$. The $\mathrm{pH}$ value was between 3.6 and 4.0 in $\mathrm{H}_{2} \mathrm{O}$ and the primary texture component is silt $(\geq 80 \%)$. For detailed soil physical and chemical information see Table 3-1.

Table 3-1: $\quad$ Texture and soil chemical properties in $0-5 \mathrm{~cm}$ mineral soil depth at the plots choosen for treatment (clear cutting) and as control (mature stand) at Otterbach site before harvesting $(n=5)$. CEC = cation exchange capacity, $B S=$ base saturation.

\begin{tabular}{lcccccccc}
\hline Plot & \multicolumn{2}{c}{ Clay } & $\begin{array}{c}\text { Silt Sand } \\
----\end{array}\left[\begin{array}{c}\text { CEC ---- } \\
{\left[\mathrm{mmol} \mathrm{kg}^{-1}\right]}\end{array}\right.$ & $\begin{array}{c}\text { BS } \\
{[\%]}\end{array}$ & $\begin{array}{c}\text { C N } \mathrm{N} / \mathrm{N} \\
---\left[\mathrm{g} \mathrm{kg}^{-1}\right]---\end{array}$ & $\begin{array}{c}\mathrm{pH} \\
\left(\mathrm{H}_{2} \mathrm{O}\right)\end{array}$ \\
\hline mature stand (silt) & 11 & 82 & 7 & 84 & 12 & 623.0 & 21 & 3.6 \\
clear cut (silt) & 11 & 80 & 9 & 80 & 10 & 432.2 & 19 & 3.8 \\
\hline
\end{tabular}

\subsubsection{Material and Methods}

A three dimensional model with a spatial dissolution of $1 \mathrm{~m}^{2}$ was used to describe the spatial variation of the radiation (Panferov et al., 2001). For calibration the radiation was measured behind the tree base lines of each side, in the centre of the clear cut and in the mature stand. From an aerial photograph the positions of the surrounding trees were digitalized and the stand structure was implemented into the model. The modelled values were cumulated on a monthly basis for 2005. Energy input along the temperature gradient transects (Fig. 3-1) were analyzed as well as collectives of 25 values parallel to the tree base lines $40 \mathrm{~m}$ behind (north-west direction as reference), at the tree base line $(0 \mathrm{~m})$ and $18 \mathrm{~m}$ into the clear cut at the north-west and south-west direction. Soil temperatures were measured with small automatically recording thermometers (Fa. Greisinger, Germany). The thermometers were installed in $10 \mathrm{~cm}$ depth, where they were inserted into the clearing orientated wall of a small pit. The registration interval was 30 minutes starting at the 15.4.2005. Six loggers with a distance of $10 \mathrm{~m}$ were installed at each orientation of the clearings edge (Fig. 3-1). 
These soil temperature transects reached from the closed stand via the tree base line to the clear cut. In addition four temperature loggers randomly were installed at the geometric centre of the clearing and deep in the mature stand. For each point of the four transects the soil temperature means of two years were calculated for each month. Mean monthly temperatures of the clear cut centre and forest interior were calculated in the same way, tested for their distribution and tested with a Mann-Whitney statistics using the statistical package R (R Core Team, 2005).

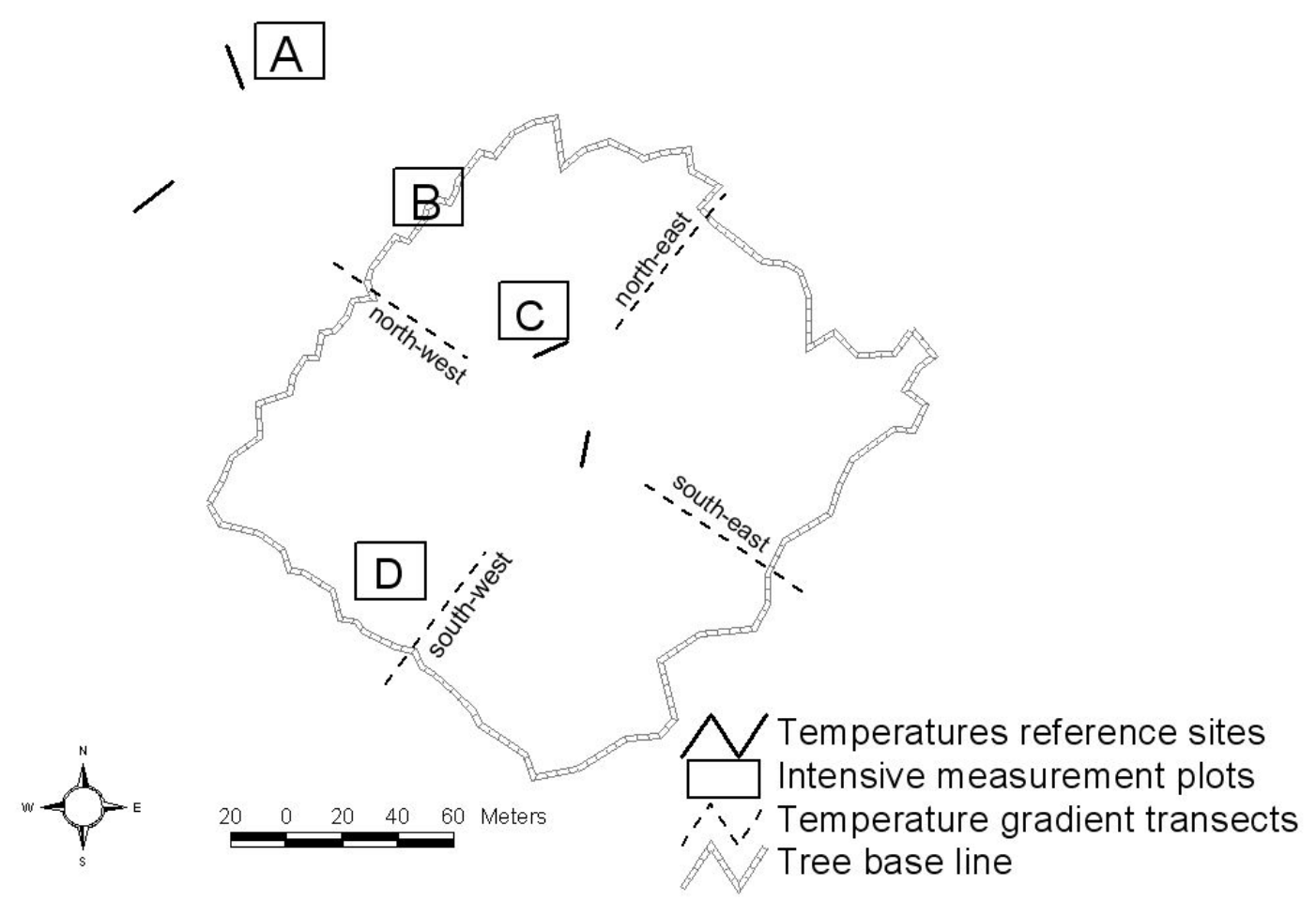

Figure 3-1: $\quad$ Plan of measurement design of the clear cut investigation field at Otterbach site.

For comparison of the steepness of the gradients and for interpolation formula 3-1 (e.g. Ewers and Didham, 2006) was used. This function describes a sigmoidal curve with an asymptote on the left and right site and a nearly linear part between the asymptotes. The averaged soil temperatures were fitted with a nonlinear least square Gauss-Newton algorithm estimate (function nls in R; R Core Team, 2005) to formula 3-1. For the left asymptote (lower temperature) the mean soil temperatures of the forest stand floor for the single month were inserted as parameters b0 and analogue the temperatures of the clear cut were inserted as parameters b1 (higher temperatures). The 1.5 fold standard deviations of the mean soil temperatures in the forest interior and at the clear cut centre were used as thresholds for significant changes to the particular reference site. The distance, where the threshold and the fitted function cross, was used to define the penetration distance. Figure 3-2 shows an example for a fitted function, the thresholds and their intersection for July. These 
distances from the tree base line were the basis for the calculation of the remaining central clear cut area, the transition zone areas and the area influenced by the cutting.

$$
T_{i}(D)=b_{0}+\frac{\left(b_{1}-b_{0}\right)}{1+e^{\left(\left(b_{2}-D_{i}\right) * b_{3}\right)}}
$$

Ti: $\quad$ soil temperature at position $\mathrm{i}$

Di: $\quad$ distance from tree base line at position $\mathrm{i}$

b0: $\quad$ mean of the site with smaller values

b1: $\quad$ mean of the site with higher values

b2: $\quad$ inflexion point (tree base line)

b3: $\quad$ slope

The parameterisations of function (3-1) for the averaged soil temperatures were used to calculate the soil temperatures for a grid with cells of $5 \mathrm{~m}$ edge length. The area was divided into four quadrants and for each quadrant the specific parameters were used for calculation of the forest floor temperatures in May, July and September. Based upon this spatial interpolation the temperature depending $\mathrm{CO}_{2}-\mathrm{C}$ releases were calculated using function (3-2) with parameters $c_{0}=0.422$ and $c_{1}=0.055$ (Bagherzadeh et al., 2008) found for forest floor in the Solling area.

$$
f(T)=c_{0} * e^{c_{1}^{*} T}
$$

$$
\begin{aligned}
& \mathrm{C}_{0} \text { : empirical coefficent } \\
& \mathrm{c} 1 \text { : empirical coefficient } \\
& \mathrm{T}: \text { temperature }
\end{aligned}
$$

ArcView GIS was used to display the modelled incoming energy from radiation and the calculated transition zones for soil temperatures. The classification of energy was done in steps of a multiplier of 42 , because 42 mega Joule are necessary to heat 1 t water from 14.5 up to $15.5^{\circ} \mathrm{C}$. 


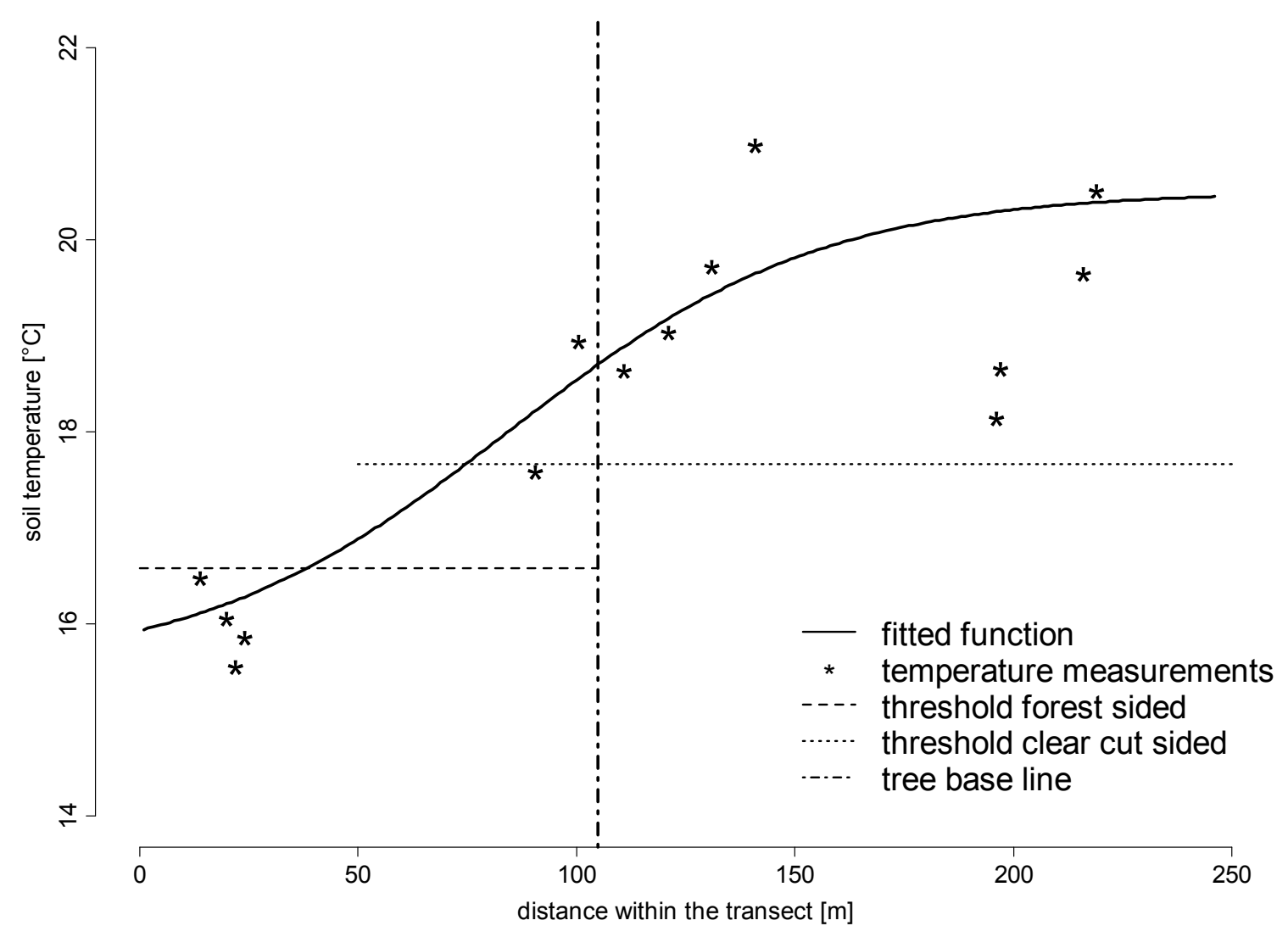

Figure 3-2: $\quad$ Graphical example for the calculation of transition zones by a function fitted to soil temperatures of the forest interior, the clear cut and the edge. The transition zone within this example would completely lay within the forested area on the left site.

\subsection{Results}

Energy input from radiation along the four transects crossing each edge of the clear cut have the same characteristics as the exponential function formula 3-1. They offer sigmoid patterns (Fig. 3-2) with a high plateau at the clear cut centre, a linear segment toward the edges and a low plateau behind the tree base line. For instance in July different gradients are obvious on the linear segment depending on the direction. The gradient has the steepest slope at the north-west edge and at the south-west it was steeper than at the north-east edge. In consequence there are differences of incoming energy before and at the tree base line depending on direction. The cumulated monthly energy input $18 \mathrm{~m}$ onto the clear cut and at the tree base line are given in Table 3-2, where the south-west and north-west aspect are compared. At the tree base line of the south-west edge (SW0) the maximum energy input occurred in September, when radiation is referred to the forest interior. The north-west edge offers a bimodal pattern with two maxima in March and September, when $474 \%$ and $680 \%$ higher radiation energy input reaches the surface compared to the forest interior. On the clear cut the north-west edge showed generally higher energy input than the south-west edge and the pattern of the annual course of the two directions were 
opposite. Between June and August the differences of relative incoming energy between the two edges were small (3-12 \%), however in March and October the highest differences were observed reaching $34 \%$. Distribution of energy input indicates differences for soil temperatures. The mean soil temperatures of two years in the clear cut and the forest interior were compared for the months between May and December and the results are presented in Table 3-3. Soil temperatures in the clear cut were significantly warmer until October. The differences reached their maximum in June and July with 3.5 and $3.6^{\circ} \mathrm{C}$ warmer temperatures in the clear cut soils. Although in November and December the clear cut exhibits colder mean soil temperatures, the small differences of $-0.4{ }^{\circ} \mathrm{C}$ were statistically not significant.

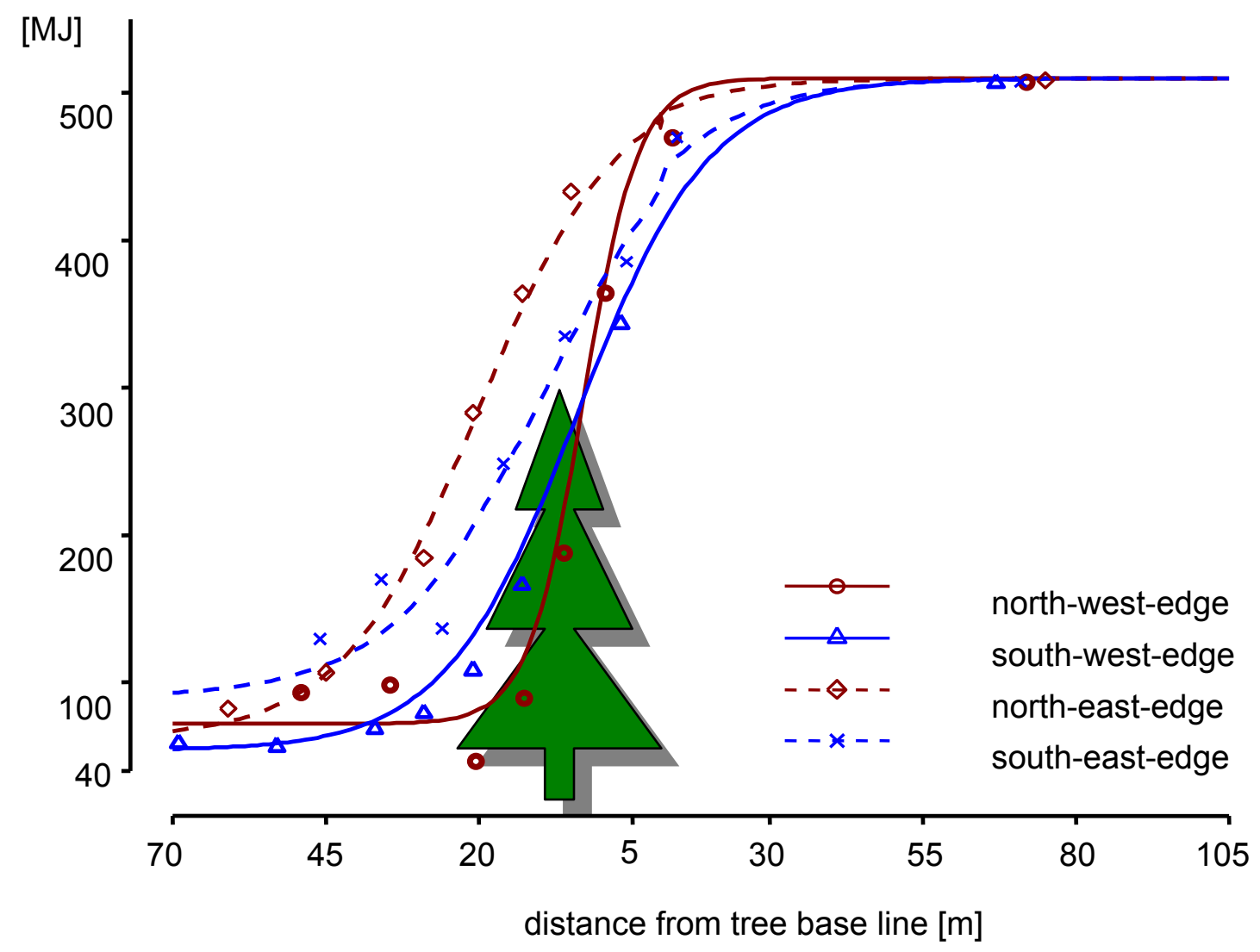

Figure 3-3: $\quad$ Local (points) and interpolated (lines) energy inputs in July in Mega Joule along four transects of different aspects from forest interior to clear cut centre. The forest interior is represented at the left hand side of the tree.

Based upon the mean monthly soil temperatures the functions for the calculation of the transition zones were fitted. In Table 3-4 the fitted parameters and the residual sum of squares are given. Within the transects the tree base line is located at $105 \mathrm{~m}$ (cf. Fig.3-2) and in May the inflexion point of function 1 laid behind the tree base line excepted the south-west edge. In July the inflexion point only was at the north-west edge behind the tree base line. However, in September the inflexion point laid onto the clear cut side at the southern orientated edges at the northern orientated edges it was 
behind the tree base line. In all cases the north-west edge offered the steepest slope (b3, Table 3-4) and the fitting algorithm generally reached the best results, indicated by small residual sum of squares. In July, when the gradient has the steepest slope, the highest residual sums of squares were obtained for the south-east, south-west and north-east edge.

For the site the two sided distances of the soil temperature gradients were given in Table 3-5 exemplary for four month. In December the soil temperatures between clear cut and forest interior did not differ, thus there was no transition zone among the two sites.

Table 3-2: $\quad$ Relative energy input $18 \mathrm{~m}$ before the tree base line and at the tree base line for both the south-west and north-west edge and the forest interior (40m behind tree base line) referred to radiation at the clear cut centre on a monthly cumulated basis.

\begin{tabular}{|c|c|c|c|c|c|c|}
\hline \multirow[t]{2}{*}{ Month } & \multicolumn{2}{|c|}{ energy input } & \multicolumn{4}{|c|}{ radiation referred to clear cut centre } \\
\hline & clear cut & Interior & SW0 & SW18 & NWO & NW18 \\
\hline January & 42 & 7 & 38 & 67 & 25 & 74 \\
\hline February & 84 & 6 & 30 & 54 & 27 & 78 \\
\hline March & 232 & 4 & 21 & 45 & 29 & 79 \\
\hline April & 365 & 10 & 35 & 67 & 43 & 82 \\
\hline May & 460 & 8 & 42 & 73 & 24 & 77 \\
\hline June & 500 & 7 & 39 & 69 & 19 & 76 \\
\hline July & 501 & 14 & 41 & 73 & 29 & 82 \\
\hline August & 394 & 14 & 33 & 67 & 40 & 85 \\
\hline September & 322 & 5 & 20 & 51 & 29 & 81 \\
\hline October & 193 & 4 & 17 & 30 & 26 & 83 \\
\hline November & 57 & 10 & 36 & 63 & 38 & 80 \\
\hline December & 27 & 10 & 41 & 74 & 27 & 71 \\
\hline
\end{tabular}

For the other seasons the results show highly asymmetric pattern. For instance at the south-west side both boarders of the transition zone were at the clear cut side and the transition to higher clear cut temperatures reaches $50 \mathrm{~m}$ onto the clear cut. The deepest transition into the forest amounted $58.6 \mathrm{~m}$ at the north-east edge in September. On the clear cut the most extended transition zone occurred at the southeast edge with $57.2 \mathrm{~m}$ in July. The resulting areas of clear cut core zone, transition zone and clear cut influenced area concerning soil temperatures are given in Table 3-5. From May to July the transition zone was of greater extent than the remaining clear cut zone and the clear cut influenced area was 1.5 to 2 fold bigger than the cut area. In July the remaining clear cut centre, the transition zone and consequently the clear cut influenced area were smallest. While the extension of the clear cut core zone area doubled from July to December (Tab 3-5), the transition zone did not constantly decrease in this time. However, the forest sided transition zone diminished not constantly, but showed bimodal pattern with higher extension in May (30917 $\left.\mathrm{m}^{2}\right)$ and September $\left(24981 \mathrm{~m}^{2}\right)$ and smaller extensions in July $\left(21072 \mathrm{~m}^{2}\right)$ and December $\left(0 \mathrm{~m}^{2}\right)$, due to the very small difference between the energy input at the clear cut and the forest stand. 
Table 3-3: $\quad$ Mean soil temperatures $\left[{ }^{\circ} \mathrm{C}\right]$ in $10 \mathrm{~cm}$ depth, calculated for the forest interior, the clear cut centre and the annual average values.

\begin{tabular}{|c|c|c|c|c|c|}
\hline Month & forest interior & $(n)$ & clear cut centre & $(n)$ & differences \\
\hline May & 9.3 & (248) & 12.2 & (248) & +2.9 \\
\hline June & 11.9 & (240) & 15.5 & (240) & +3.6 \\
\hline July & 15.1 & (248) & 18.6 & (248) & +3.0 \\
\hline August & 13.6 & (248) & 16.3 & (248) & +2.7 \\
\hline September & 13.8 & (240) & 15.4 & (240) & +1.6 \\
\hline October & 11.4 & (248) & 11.7 & (248) & +0.3 \\
\hline November & 7.8 & (240) & 7.6 & (240) & -0.2 \\
\hline December & 4.9 & (248) & 4.5 & (248) & -0.4 \\
\hline annual average & 8.2 & & 9.6 & * & \\
\hline
\end{tabular}

* indicates significant differences to forest interior $(p=0.01)$

Table 3-4: $\quad$ Parameters and residual sum of squares (rss) of the soil temperatures fitted with formula 1 for each direction.

\begin{tabular}{|c|c|c|c|c|c|c|}
\hline Month & Direction & $\begin{array}{r}\text { bo } \\
{\left[{ }^{\circ} \mathrm{C}\right]} \\
\end{array}$ & $\begin{array}{r}\mathrm{b} 1 \\
{\left[{ }^{\circ} \mathrm{C}\right]} \\
\end{array}$ & $\begin{array}{r}\mathrm{b} 2 \\
{[\mathrm{~m}]}\end{array}$ & b3 & rss \\
\hline \multicolumn{7}{|l|}{ May } \\
\hline & South-west & 9.3 & 12.2 & 109.6 & 0.09950 & 1.02 \\
\hline & South-east & 9.3 & 12.2 & 98.8 & 0.04563 & 0.86 \\
\hline & North-east & 9.3 & 12.2 & 97.3 & 0.08506 & 1.60 \\
\hline & North-west & 9.3 & 12.2 & 95.1 & 0.11390 & 0.49 \\
\hline \multicolumn{7}{|l|}{ July } \\
\hline & South-west & 15.1 & 18.6 & 115.6 & 0.10690 & 3.18 \\
\hline & South-east & 15.1 & 18.6 & 136.5 & 0.03378 & 3.03 \\
\hline & North-east & 15.1 & 18.6 & 109.1 & 0.04701 & 2.84 \\
\hline & North-west & 15.1 & 18.6 & 96.1 & 0.10750 & 0.11 \\
\hline \multicolumn{7}{|c|}{ September } \\
\hline & South-west & 13.8 & 15.4 & 143.2 & 0.05911 & 0.71 \\
\hline & South-east & 13.8 & 15.4 & 131.8 & 0.02830 & 1.61 \\
\hline & North-east & 13.8 & 15.4 & 77.2 & 0.06492 & 0.90 \\
\hline & North-west & 13.8 & 15.4 & 93.3 & 1.01980 & 0.81 \\
\hline
\end{tabular}

Table 3-5: Width of transition zones for soil temperature, distances are given for both sides into the forest interior (negative) and onto the clear cut site (positive) in meter from tree base line.

\begin{tabular}{|c|c|c|c|c|c|c|c|c|c|}
\hline \multirow{2}{*}{$\begin{array}{l}\text { Direction } \\
\text { Month } \\
\text { May }\end{array}$} & \multicolumn{2}{|c|}{$\begin{array}{l}\text { south-west } \\
\text { interior clear cut }\end{array}$} & \multicolumn{2}{|c|}{$\begin{array}{l}\text { south-east } \\
\text { interior clear cut }\end{array}$} & {$[\mathrm{m}]$} & \multicolumn{2}{|c|}{$\begin{array}{l}\text { north-east } \\
\text { interior clear cut }\end{array}$} & \multicolumn{2}{|c|}{$\begin{array}{l}\text { north-west } \\
\text { interior clear cut }\end{array}$} \\
\hline & -18.0 & 24.9 & -55.5 & 37.9 & & -34.2 & 15.9 & -29.7 & 7.8 \\
\hline July & -6.5 & 18.7 & -22.9 & 57.2 & & -34.9 & 22.6 & -26.0 & -0.9 \\
\hline Sept. & 4.4 & 49.6 & -43.9 & 50.6 & & -58.6 & -17.4 & -13.7 & 11.1 \\
\hline Dec. & 0.0 & 0.0 & 0.0 & 0.0 & & 0.0 & 0.0 & 0.0 & 0.0 \\
\hline
\end{tabular}

The calculated core zones and the transition zones concerning soil temperatures for the energy input in 2005 are shown in figures 3-4 to 3-6 for the months May, July and September. The figures demonstrate the different spatio-temporal dynamics of incoming energy and consequently the resulting soil temperatures. In May at the treeless area the highest monthly energy input was 469 mega Joule and the energy input distributes nearly symmetrically around the midpoint of the clear cut (Fig. 3-4). The calculated clear cut core zone concerning to soil temperatures is shift to the 
north-west direction. In south-west and north-east direction the core zone is of greater extent than the zone of highest energy input, but almost symmetrical to the energy distribution. In July 2005 the surface of the cut area received a maximum of 550 mega Joule as shown in figure 3-5. The area where more than 420 mega Joule were incoming is bigger than in may, but has shifted to the north-east and south-east edge, where the input was higher than in opposite direction. Even the areas behind the tree base line receive higher energy at the eastern edges. When the slope of the gradient becomes steeper between clear cut and forest in July the forest sided soil transition zone becomes smaller at the north-east and south-east orientation (Fig.3-5) compared to May. In contrast to the cumulative energy input the shift of the soil temperature core zone to the north-west edge is more pronounced. The pattern for September, when the maximal cumulative monthly energy input was 324 mega Joule, is presented in figure 3-6. The area that represents the highest energy input was closer to the northern edges than to the edges with southern orientation. The centre of highest soil temperatures shows this displacement and influences the remnant forest of the northern edges. However on the south-west side the remaining stand has a strong shading effect on the edge of the cut site in September.

To demonstrate the impact of the differences of the soil temperature in different zones, the impact on the heterotrophic emissions of $\mathrm{CO}_{2}$ was calculated. The calculations are based on a clear cut of $182 * 182 \mathrm{~m}$ and the transition zones for the month May, July and September. The clear cut is embedded in a 10 ha spruce forest. The temperature dependencies of the $\mathrm{CO}_{2}$ emissions from the forest floors of mature spruce forests in the Solling area was taken from Bagherzadeh et al., 2008. In Table 3-6 the different areas are presented, showing different mean soil temperatures.

The $\mathrm{CO}_{2}$ emission rates of the stand situation lie between 0.696 and $1.020 \mathrm{~g}$ $\mathrm{CO}_{2}{ }^{-} \mathrm{C} \mathrm{m} \mathrm{m}^{-2} \mathrm{~d}^{-1}$, those of the clear cut were higher by 7 to $16 \%$, see Table $3-7$. The transition zone range in between. To calculate the total $\mathrm{CO}_{2}$ emission of a clear cut embedded in a $10 \mathrm{~h}$ spruce forest, two approaches were used. On the one hand side the area of the three zones (clear cut, transition, forest; Table 3-6) and their mean monthly soil temperatures were used, on the other hand side only the total clear cut area and the total stand area were used. In Table 3-7 is shown that there are significant differences in $\mathrm{CO} 2$ emissions between the different months. However the simple tow area approach underestimates the total emission only by 1.6 to $3.6 \%$. 
Table 3-6: $\quad$ Areas $\left[\mathrm{m}^{2}\right]$ of clear cut centre, transition zones and total clear cut influenced area. The calculation was done for a square of $182 \mathrm{~m}$ with linear tree base line. Not included into the calculation are the transition zones of the south-east edge.

\begin{tabular}{|c|c|c|c|c|}
\hline $\begin{array}{l}\text { Zone } \\
\text { Month }\end{array}$ & $\begin{array}{l}\text { clear cut } \\
\text { centre }\end{array}$ & $\begin{array}{l}\text { transition zone } \\
\text { common }\end{array}$ & $\begin{array}{c}\text { forest sided } \\
\text { common }\end{array}$ & clear cut influenced \\
\hline May & 30917 & 46080 & 30917 & 76997 \\
\hline July & 16319 & 37895 & 21072 & 54214 \\
\hline September & 20836 & 40526 & 24981 & 61362 \\
\hline December & 33140 & 0 & 0 & 33140 \\
\hline
\end{tabular}

Table 3-7: Mean heterotrophic carbon dioxide emission based on soil temperatures and the Arrhenius kinetics for forest floor at Solling sites. The monthly zone emissions are calculated for a $100000 \mathrm{~m}^{2}$ big forest site. Two calculations are compared, where the first used three zones with variable extensions and the second used the two zones clear cut and forest with constant extensions of $33140 \mathrm{~m}^{2}$ and $66860 \mathrm{~m}^{2}$, respectively.

\begin{tabular}{|c|c|c|c|c|}
\hline Month & Zone & $\begin{array}{l}\text { mean calculated emission } \\
\quad---\mathrm{g} \mathrm{CO}_{2}-\mathrm{C} \mathrm{m}^{-2} \mathrm{~d}^{-1}--\end{array}$ & $\begin{array}{c}\text { monthly zon } \\
--- \text { kg } \mathrm{CO}_{2}-\mathrm{C} \\
\text { three zone } \\
---\quad \text { appr }\end{array}$ & $\begin{array}{l}\text { emission } \\
\text { onth }^{-1}--- \\
\text { two zone } \\
\text { ach --- }\end{array}$ \\
\hline \multicolumn{5}{|l|}{ May } \\
\hline & clear cut centre & 0.807 & 448.4 & 829.1 \\
\hline & transition zone & 0.747 & 1292.0 & \\
\hline & forest & 0.696 & 567.2 & 1442.6 \\
\hline & sum & & 2307.6 & 2271.7 \\
\hline \multicolumn{5}{|l|}{ July } \\
\hline & clear cut centre & 1.173 & 944.4 & 1205.1 \\
\hline & transition zone & 1.073 & 2064.9 & \\
\hline & forest & 1.020 & 378.8 & 2114.1 \\
\hline & sum & & 3388.1 & 3319.2 \\
\hline \multicolumn{5}{|c|}{ September } \\
\hline & clear cut centre & 0.989 & 960.1 & 983.3 \\
\hline & transition zone & 0.948 & 1580.4 & \\
\hline & forest & 0.927 & 410.1 & 1859.4 \\
\hline & sum & & 2950.6 & 2842.7 \\
\hline
\end{tabular}




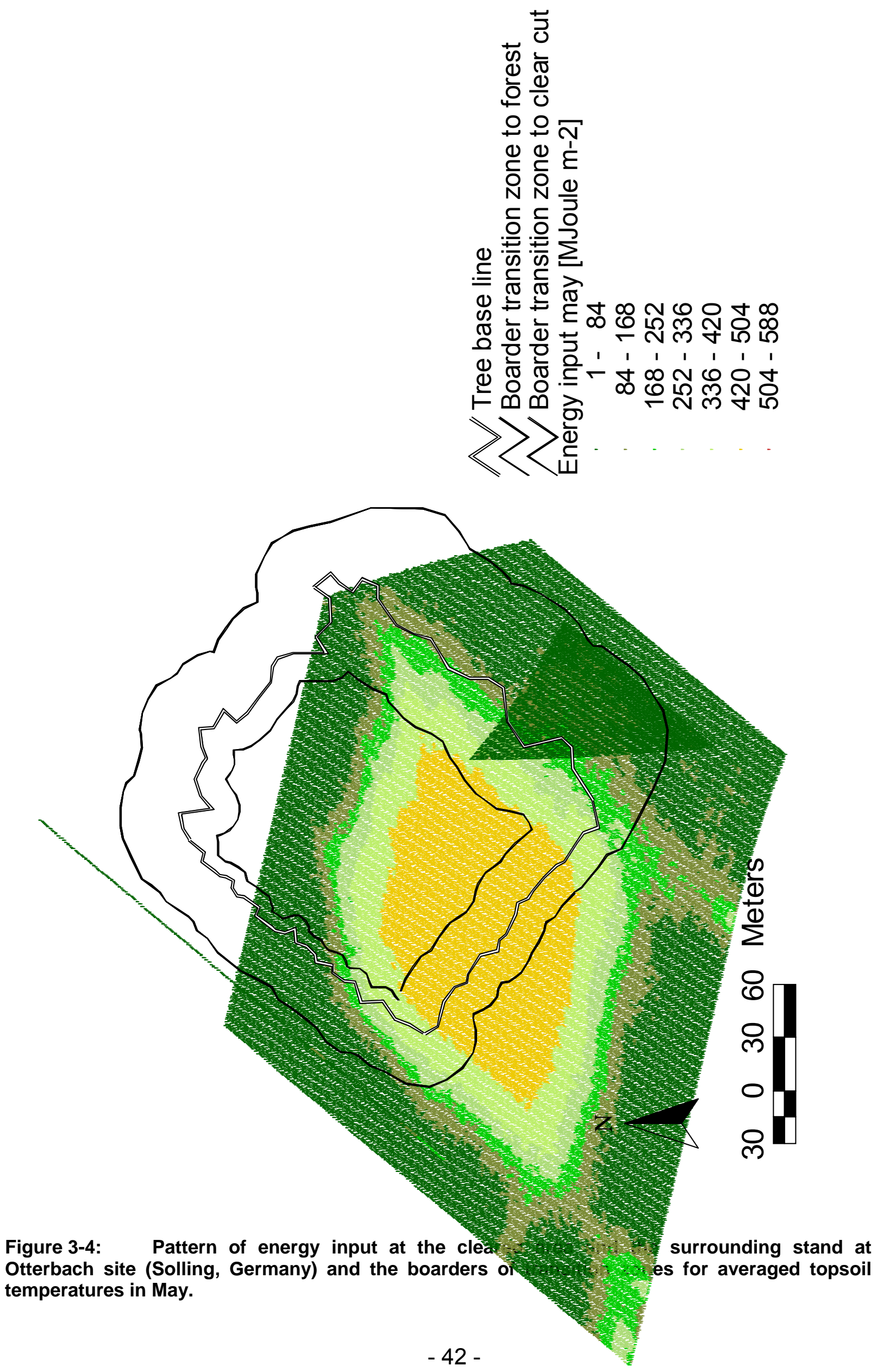



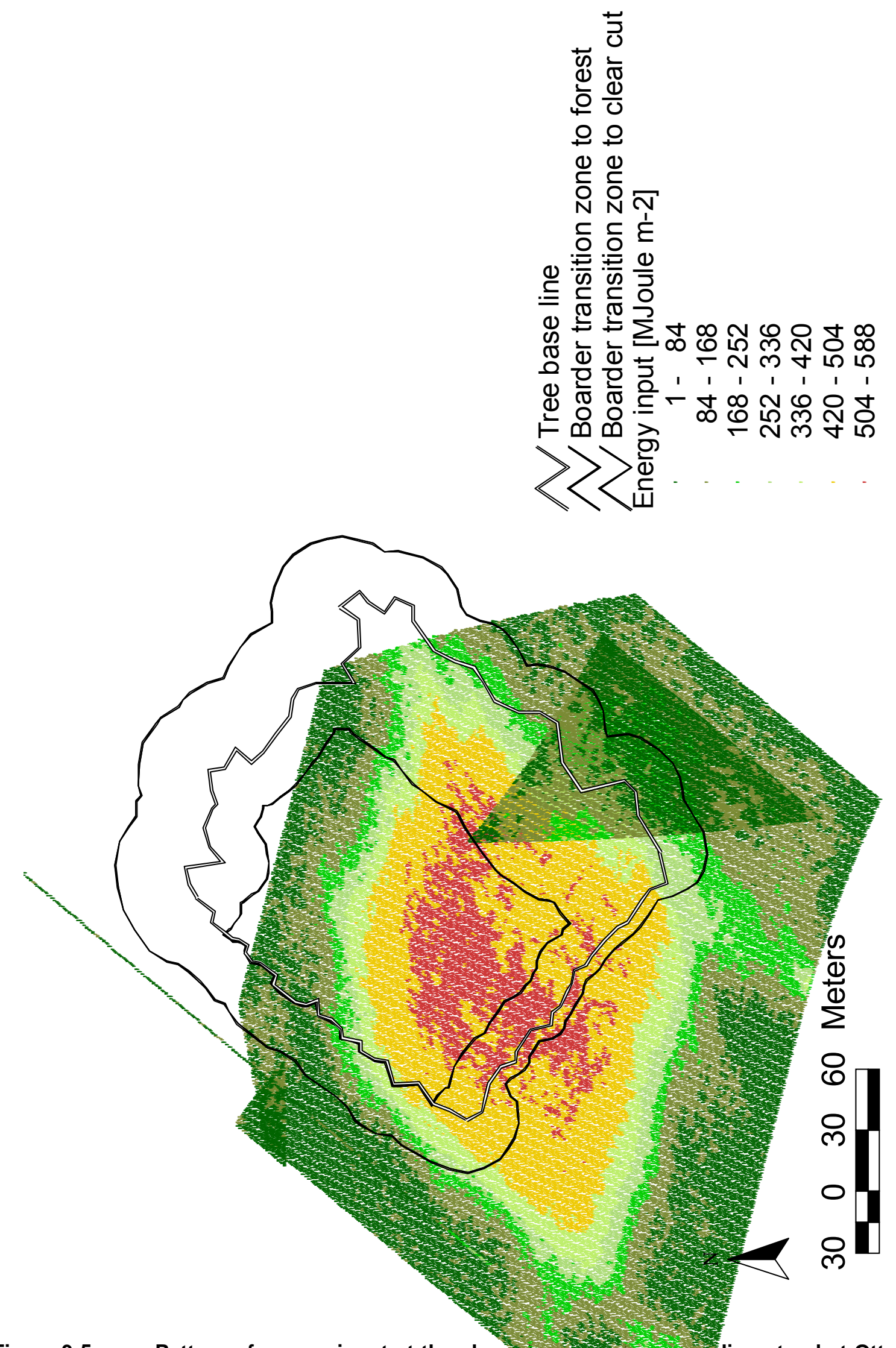

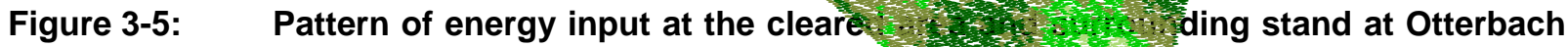
site (Solling, Germany) and the transition zones of avercutely 


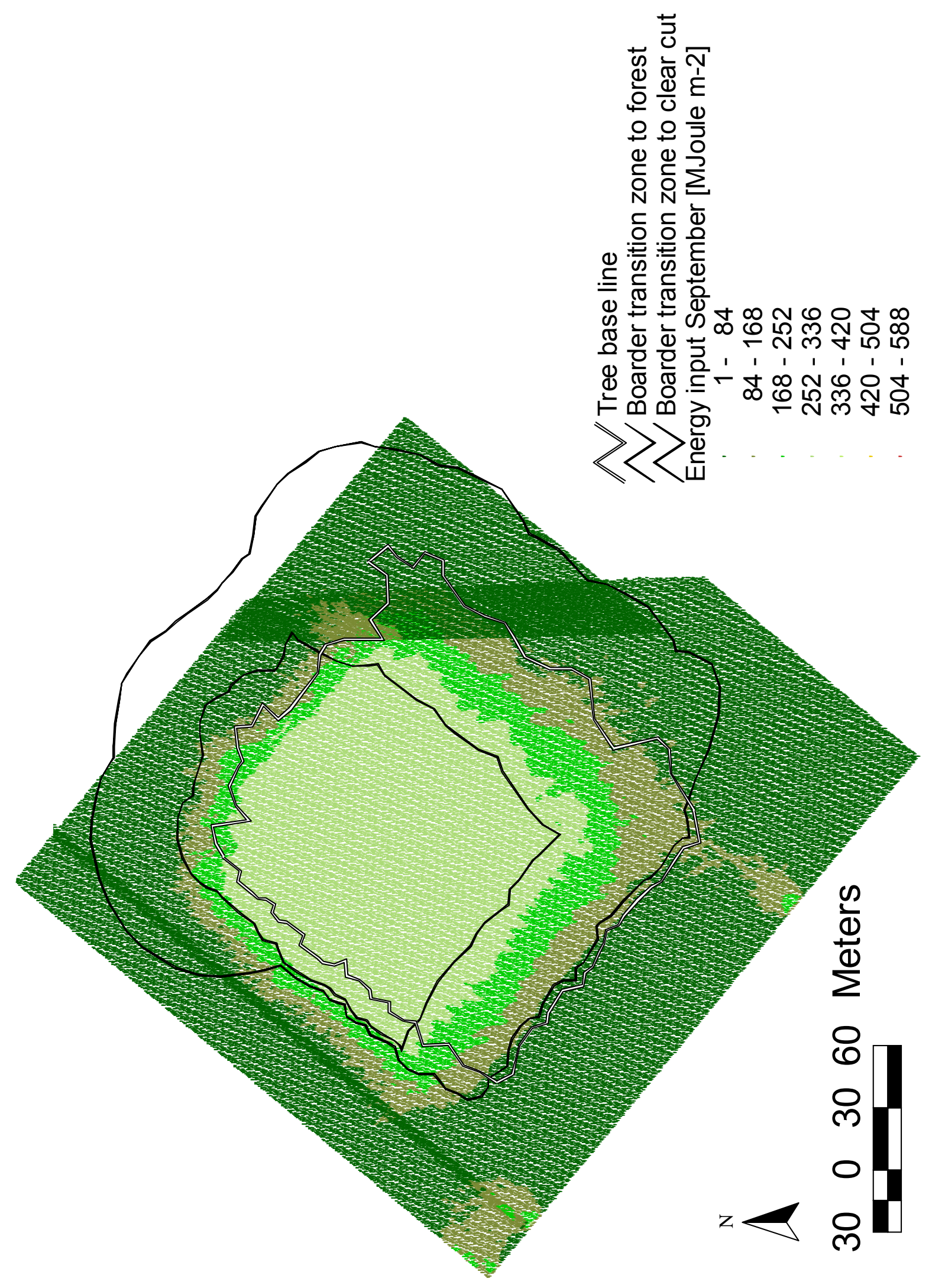

Figure 3-6: $\quad$ Pattern of energy input at the cleared area and surrounding stand at Otterbach site (Solling, Germany) and the transition zones of averaged topsoil temperatures in September. 


\subsection{Discussion}

The chosen exponential function is an appropriate model for the description of environmental gradients at small clearings. Some abiotic parameters like air temperature, vapour pressure deficit and wind speed exhibit similar sigmoid pattern on edges in previous studies from other climatic regions and forest types (Davies-Collie et al., 2000). A similar performance was shown in the present study for energy input and soil temperature along transects. The used exponential function implicates a gradient of the observed variable between two different adjacent ecological units of a landscape. Soil temperatures showed gradients within the vegetation period, but not in winter time. However it has to be tested, if the premises for using of a sigmoid function are achieved, because not all variables peak at the clear cut centre. For example, Chen et al. (1993) observed higher values of air temperature and relative air moisture adjacent to the edges than in the centre of a 15 year old clear cut. In case a gradient exists the approach is suitable to gain more ecological information through the intersection of multiple ecological parameters. In this way it can help to condensate abiotic environmental parameters into a simplified format for the ecological assessments.

Temperature is an important controlling factor. Increases of soil temperatures accelerate chemical processes and this likewise affects processes like germination or development of plant, activity of soil microorganisms (mineralization) and changes of soil material properties like surface tension of soil water. Heat input results primarily by radiation. The intensity is depending on multiple factors like latitude, season and daytime, weather, aspect, inclination, soil colour, soil type and soil cover. The transformation of radiation energy into soil heat is modified by soil moisture content (e.g. Al-Karaghouli et al., 2001), organic surface layer (Kasischke and Johnstone, 2005), vegetation cover (Scull, 2007) due to shading and water demand and wind speed (Cellier et al., 1996). Heat is lost in terms of long wave radiation with a negative balance during night. All these parameters are highly variable in time or space and make it impossible to calculate soil temperatures directly from radiation alone. Nevertheless calculated soil temperature transition zones related to radiation classes were partly in good agreement. This especially holds for the clear cut sided parts of the southwest edge. This indicates that radiation is still is dominating the soil temperatures and zones with different soil temperature performance can be explored. The south east edge exhibited the strongest deviation of energy input and soil temperature due to the rapid development of a vegetation cover and the structure of the adjacent stand. This stand was build by oak showing different structure and foliation dynamics compared with the Norway spruce stand. Bracken dominated the ground vegetation on the south-east edge, which causes differences in shading and transpiration, whereas the modelled radiation represents the energy input above the vegetation. Some forest sided boarders were not definable. The changes in radiation were comparably small behind the tree base line. 
In July the areas with highest input values were speckled, but the accordance of the calculated boarder of the south-eastern core zone and maximum radiation values is acceptable. The elongation of high incoming radiation to the eastern corner is a consequence of the geography (aspect and inclination). These factors could not be displayed with only one transect per site. Further reason for deviation between received energy and soil temperature are differences in the soil water status. On the forest sided north-west edge the soil was dry within the vegetation seasons (see chapter 4, Fröhlich et al., 2009). Due to the water demand of the vegetation the transpiration increases strongly in vicinity to the forest (Diaz et al., 2007). For instance a zone of soil moisture depletion between 40 and $80 \mathrm{~m}$ was observed at a Brazilian forest edge in vicinity to pasture (Camargo and Kapos, 1995). In consequence the soil has lower heat capacity and deviation from energy input classes is credible. Differences to other edges were plausible for the same reason, because different variability of soil moisture caused by edge orientation were found previously (Chen et al., 1993).

Outlier adjusted interpolation schemes are needed for spatial patterns and ecological predictions. As seen above, the strongest disturbing variables were the vegetation cover and the soil moisture content for an exact indication of transition zones based on radiation. Both parameters however were found to be highly variable. The canopy of the spruce stand is very heterogeneous and diffuse non-intercepted radiation could only rudimentarily be described in model but may be of great influence on soil temperature distribution. Moreover the high variability of soil moisture contents has to be included in the calculation of transition zones. If these influences were not randomly distributed at any site, this will affect the calculation of the transition zone. Advices for such directive errors were not noticed in this study

The approach of the present study offers advantages for needed resources. The minimal sample number to calculate the variance of a core-zone is four with a tolerance limit of $1 \%$ for the standard deviation and a probability error of $1 \%$ (Lozan, 1998). Chen et al. (1995) found higher differences in the soil temperatures than in air temperatures between forest edge and clearing. The distance from edge into the forest, where the impact was significant, was estimated from scatter-plots to be smaller than $60 \mathrm{~m}$ including diurnal variation. The value found by Chen et al. (1995) and our observations using larger time scales are in accordance. However, for the clear cut side the transition zones can even be larger (Tab. 3-5). To calculate the extent of edge influence based on scatter plots is not a robust method. In our study we used the variance as a threshold. The needed measurement equipment is smaller with this method than for investigations where the wavelet transformation was used. Moreover, peaks that indicate the end of transition zone may not always be clearly defined using the wavelet transformation process (Redding et al., 2003). Didham and Lawton (1999) used logarithmic linear regression, which did not satisfy the conditions 
of the covariance analysis which should deliver the transition boarders. Moreover for some variables linear regression is not appropriate and the use of intersection of $95 \%$ confidence bounds for the regression and the $95 \%$ confidence interval for variation of the centre is not useful, too.

The distances calculated for the transition zones were in good agreement with the findings by other authors, indicating the plausibility of our methods. Transition zones for several variables were given from different geographical zones, forest types and methods. A rapid decrease behind the tree base line of shortwave radiation was found by Chen et al. (1995) for a Douglas fir forest. The transition zone of the shortwave radiation in the Douglas fir forest reached the level of the forest interior 30-60 m behind the tree base line. Even the edge influence in the cited study varied greatly among the orientations $(<20 \mathrm{~m}$ at the north facing edge to $60 \mathrm{~m}$ at the south-facing edge), what is consistent with our presented findings. In a Douglas fir dominated forest near Washington (USA) south and west facing transects represented warmer areas than north and east facing transects (Heithecker and Halpern, 2007) and transmitted light showed the greatest reduction within 10 to $15 \mathrm{~m}$ behind the tree base line. The last finding is in accordance with the modelled values presented here. A zone of soil moisture depletion between 40 and $80 \mathrm{~m}$ was observed at a Brazilian forest edge in vicinity to pasture (Camargo and Kapos, 1995). In contrast a rapid change in soil temperature at $5 \mathrm{~cm}$ depth was observed at an edge of a broadleaf rainforest in New Zealand (Davies-Collie et al., 2000). The rapid decrease of soil temperature $5 \mathrm{~m}$ behind the tree base line was in good agreement with measurements of photosynthetic active radiation at the New Zealand site. This demonstrates that radiation can be an indicator for soil temperatures of the upper mineral horizon and the impact of age, foliation type and latitude on the occurrence of transition zones.

To demonstrate that the changes in soil temperatures induced by the clear cut create changes in ecological processes, the emission of $\mathrm{CO}_{2}$ by heterotrophic respiration was calculated. The function which describes the temperature dependence of the organic matter mineralization was derived under optimal water contents of the forest floor (Bagherzadeh et al, 2008). Temperature dependence of the decomposer community was previously shown with statistical significance (e.g. Pumpanen et al, 2004; Kätterer et al., 1998). Therefore changing water contents under field conditions might influence the true $\mathrm{CO}_{2}$ emissions (Fierer et al, 2003; Epron et al., 1999), so that our rates calculated only show the order of magnitude of the changes.

Table 3-7 demonstrates that the emission rates of $\mathrm{CO}_{2}$ not only change during the year, but also exhibit differences between the three zones distinguishable. The increased emission rates of the clear cut forest floor compared with the closed stand shows that the decomposition of the forest floor is accelerated by 7 to $16 \%$. This will lead to a reduction of the carbon stock and to higher $\mathrm{CO}_{2}$ input to the atmosphere. 
Our study clearly demonstrate, that a clear cut in a mature spruce stand can not regarded as a homogenous area with respect to the incoming radiation, precipitation and the soil internal states and processes influenced by them. Depending on the site of the clear cut, the height of the surrounding trees and the season of the year we found a transition zone of changing extensions between the stand internal conditions and the not edge affected centre of the clear cut. These transition zones extend to both sides of the tree boarder line.

From our finding one can conclude that for assessment of the ecological impact of clear cuts it is not sufficient to describe the situation in the centre, because the transiotion zone with its deviating conditions may cover larger areas than the clear cut centre.

\section{Acknowledgements}

This research is part of the common efforts of the projects BE 713/27-1, GR 738/16-2 and ME 2078/1-1, which were supported by the 'Deutsche Forschungsgemeinschaft' (DFG). The authors would like to thank for financial grant. 


\subsection{References}

Al-Karaghouli, A.A., Al-Kayssi, A.W., 2001. Influence of soil moisture content on soil solarisation efficiency. Renewable Energy 24, 131-144.

Bagherzadeh, A., Brumme, R., Beese, F., 2008. Temperature dependence of carbon mineralization and nitrous oxide emission in a temperate forest ecosystem. Journal of Forestry Research 19, 107-112.

Camargo, J.L.C., Kapos V., 1995. Complex edge effects on soil-moisture and microclimate in central amazonian forest. Journal of Tropical Ecology 11, 205-221.

Carvalho, K.S., Vasconcelos, H.L., 1999. Forest Fragmentation in central Amazonia and its effects on litter-dwelling ants. Biological Conservation 91, 151-157.

Cellier, P., Richard, G., Robin, P., 1996. Partition of sensible heat fluxes into bare soil and the atmosphere. Agricultural and Forest Meteorology 82, 245-265.

Chen, J., Franklin, J.F., Spies, T.A., 1993. An empirical model for predicting diurnal air-temperature gradients from edge into old growth Douglas-fir forest. Ecological Modelling 67, 179 -198.

Chen, J., Franklin, J.F., Spies, T.A., 1995. Growing-season microclimatic gradients from clearcut edges into old-growth Douglas-fir forests. Ecological Applications 5, 74-86.

Davies-Colley, R.J., Payne, G.W., van Elswijk, M., 2000. Microclimate gradients across a forest edge. New Zealand Journal of Ecology 24, 111-121.

Diaz, M.F., Bigelow, S., Armesto, J.J., 2007. Alteration of the hydrologic cycle due to forest clearing and its consequences for rainforest succession. Forest Ecology and Management 244, 32-40.

Didham, R.K., 1998. Altered leaf-litter decomposition rates in tropical forest fragments. Oecologia 116, 397-406.

Didham, R.K., Lawton, J.H., 1999. Edge structure determines the magnitude of changes in microclimate and vegetation structure in tropical forest fragments. Biotropica 31, 17-31.

Epron, D., Farque, L., Lucot, E., Badot, P.M., 1999. Soil $\mathrm{CO}_{2}$ efflux in a beech forest: dependence on soil temperature and soil water content. Annals of Forest Science 56, 3, 221-226.

Ewers, R.M., Didham, R.K., 2006. Continuous response functions for quantifying the strength of edge effects. Journal of Applied Ecology 43, 527-536.

Fierer, N., Allen, A.S., Schimel, J.P., Holden, P.A., 2003. Controls on microbial $\mathrm{CO}_{2}$ production: a comparison of surface and subsurface soil horizons. Global Change Biology, 9, 1322-1332.

Fischer-Bruns, I., von Storch, H., González-Rouco, J.F., Zorita, A.E., 2005. Modelling the variability of midlatitude storm activity on decadal to century time scales. Climate Dynamics, 25, 461-476.

Fonseca, C.R., Joner, F., 2007. Two-sided edge effect studies and the restoration of endangered ecosystems. Restoration Ecology 15, 613-619.

Fröhlich, D., Klinck, U., Radler, K., Beese, F., 2009. Räumliche Modifikationen des Bodenwasserhaushalts durch Kahlschlag. In: Raumzeitliche Dynamik der Parameter des Energie-, Wasser und Spurengashaushalts nach Kleinkahlschlag, Dissertation. 
Harper, K.A., Macdonald, E.S., 2002. Structure and composition of edges next to regenerating clearcuts in mixed-wood boreal forest. Journal of Vegetation Science 13, 535-546.

Heithecker, T.D., Halpern, C.B., 2007. Edge-related gradients in microclimate in forest aggregates following structural retention harvests in western Washington. Forest Ecology and Management 248,163-173.

Kapos, V., Ganade, G., Matsui, E., Victoria E.L., 1993. Partial-Derivative-C-13 as an indicatior of edge effects in tropical rain-forest reserves. Journal of Ecology 81, 425-432.

Kätterer, T., Reichenstein, M., Andrén, O., Lomander, A., 1998. Temperature dependence of organic matter decomposition: a critical review using literature data analyzed with different models. Biology and Fertility of Soils, 27, 258-262.

Kasischke, E.S., Johnstone, J.F., 2005. Variation in postfire organic layer thickness in a black spruce forest complex in interior Alaska and its effects on soil temperature and moisture. Canadian Journal of Forest Research 35, 2164-2177.

Lewis, T., 1998. The effect of deforestation on ground surface temperatures. Global and Planetary Change, 18, 1-13.

Lovejoy, T. E., Bierregaard, R.O., Rylands Jr., A.B., Malcolm, J.R., Quintela, C.E., Harper, L.H., Brown Jr., K.S., Powell, A.H., Powell G.V.N., Schubart, H.O.R., Hays, M.B., 1986. Edge and other effects of isolation on Amazon forest fragments. Pages 257-285 in M. E. Soule, Editor. Conservation biology: the science of scarcity and diversity. Sinauer Associates, Sunderland, Massachusetts, USA.

Lozan, J.L., Kausch, H., 1998. Angewandte Statistik für Naturwissenschaftler. Parey Verlag, Berlin.

Panferov, O., Knyazikhin, Y., Myneni, R.B., Szarzynski, J., Engwald, S., Schnitzler, K.G., Gravenhorst, G., 2001. The role of canopy structure in the spectral variation of transmission and absorption of solar radiation in vegetation canopies. IEEE Transactions on Geoscience and Remote Sensing, 39, 241-253.

Pinto, J.G., Fröhlich, E.L., Leckebusch, G.C., Ulbrich, U., 2007. Changing European storm loss potentials under modified climate conditions according to ensemble simulations of the ECHAM5/MPIOM1 GCM. Nat. Hazards Earth Syst. Sci., 7, 165-175.

Pumpanen, J., Westman, C.J., Ilvesniemi, H., 2004. Soil $\mathrm{CO}_{2}$ efflux from a podzolic forest soil before and after forest clear-cutting and site preparation. Boreal Environment Research, 9, 199-212.

R statistical Package: R Development Core Team, 2005.

Redding, T.E., Hope, G.D., Fortin, M.-J., Schmidt, M.G., Bailey, W.G., 2003. Spatial patterns of soil temperature and moisture across sub-alpine forest-clearcut edges in the southern interior of British Columbia. Canadian Journal of Soil Science 84, 121-130.

Rubinstein, A., Vasconcelos, H.J., 2005. Leaf-litter decomposition in Amazonian forest fragments. Journal of Tropical Ecology 21, 699-702.

Scull, P., 2007. Changes in soil temperature associated with reforestation in central New-York state. Physical Gography 28, 360-373. 
Sizer, N., Tanner, E.V.J., 1999. Responses of woody plant seedlings to edge formation in a lowland tropical rainforest, Amazonia. Biological Conservation 91, 135-142. 


\section{Räumliche Modifikationen des Bodenwasserhaushalts durch Kahlschlag}

Fröhlich D. ${ }^{1}$, U. Klinck ${ }^{2}$, K. Radler ${ }^{3}$ und F. Beese ${ }^{1}$

1 Büsgeninstitut, Abteilung Ökopedologie der gemäßigten Breiten und Borealen Zonen. Büsgenweg 2, 37077 Göttingen

2 Nordwestdeutsche forstliche Versuchsanstalt, Abteilung D, Grätzelstrasse 5, 37000 Göttingen

3 Büsgeninstitut, Abteilung Bioklimatologie, Büsgenweg 2, 37077 Göttingen

Ansprechpartner: Daniel Fröhlich

\subsection{Zusammenfassung}

Die Wälder Mitteleuropas sind bis auf wenige Ausnahmen bewirtschaftet. Ein Ziel dieser Bewirtschaftung ist die Erhöhung des Anteils von Laub- und Mischwäldern. Eine Möglichkeit zum Umbau von Beständen besteht in der Durchführung von Kleinkahlschlägen. Die zentralen Auswirkungen von Kahlschlägen auf den Wasserhaushalt wurden vielfach dargestellt, aber wenig berücksichtigt wurden bisher die peripheren Bereiche solcher Kahlschlagflächen, obwohl dort starke Gradienten auftreten können und diese Bereiche beachtliche Flächenanteile einnehmen können.

Zur differenzierteren Betrachtung der Komponenten des Wasserhaushalts wurden in einem Fichtenaltbestand, an dessen Rand zum Kahlschlag, im Zentrum des Kahlschlags und an der Peripherie des Kahlschlags die bodenphysikalischen Parameter so wie in hoher zeitlicher Auflösung die Bodenmatrixpotentiale erfasst. Meteorologische Parameter wurden im Altbestand, im Kahlschlagzentrum und an dessen Rändern gemessen. Mit diesen zeitlich variablen Eingangsgrößen wurde mit dem modularen Modellsystem EXPERT-N die raumzeitliche Dynamik der hydrologischen Parameter in verschiedenen Durchgängen modelliert. Ein Modellauf wurde unter der Prämisse durchgeführt, dass die Verhältnisse auf der Freifläche und im Zentrum des Kahlschlags auf die jeweiligen Randbereiche übertragbar sind. In einem weiteren Durchlauf wurden die Eingangsparameter auf der Grundlage der Erkenntnisse über die Strahlungsverhältnisse an den Randbereichen modifiziert und mit dem ersten Durchlauf verglichen.

Die Arbeit zeigt, dass die Verhältnisse im Zentrum nicht das hydrologische Geschehen der Gesamtfläche repräsentieren. Die Einflüsse des Bestands auf die Randbereiche des Kahlschlags führten teilweise zu erhöhten Wassergehalten. In Bereichen des Bestandes, die an den Kahlschlag grenzten, traten vermehrt Tage mit kritischen Matrixpotenitalen für Bäume auf. Die Darstellung dieser Auswirkungen mittels des Wasserhaushaltsmodells wurde unter Berücksichtigung der horizontalen Effekte erzielt. 


\subsection{Einleitung}

Pflanzen sind eine wichtige Regelgröße im Wasserhaushalt von terrestrischen Ökosystemen und ihre Anteile als auch ihre Verteilung in unterschiedlichen Ökosystemen bestimmen das hydrologische Geschehen in Wassereinzugsgebieten (Lorz et al., 2007). Wälder mit einem Flächenanteil von etwa $30 \%$ in Deutschland haben aufgrund ihrer Artenzusammensetzung und Oberflächenbeschaffenheit (Rauhigkeit, Bedeckungsgrade, Albedo) einen besonders großen Einfluss auf Energie- und Stoffumsätze. Da die Wälder bis auf wenige Ausnahmen in Mitteleuropa bewirtschaftet werden, bedarf es der Abschätzung der Wirkung forstlicher Eingriffe auf hydrologische Größen wie die Grundwasserspende oder den Gebietswasserabfluss. Eine Prämisse der heutigen Waldbewirtschaftung ist die Erhöhung des Anteils von Laub- und Mischwäldern. Je nach Ausgangslage kann dies durch verschiedene Maßnahmen, wie z.B. Einzelstammentnahmen oder Kleinkahlschläge, geschehen.

In einer Reihe von Untersuchungen konnte gezeigt werden, dass sich der Wechsel von Nadel- zu Laubbaumbeständen auf die den Wasserhaushalts beeinflussenden Größen auswirkt und unter anderem eine höhere Grundwasserspende zur Folge hat (u.a. Peschel et al., 2002; Armbruster et al., 2004; Benecke, 1984). Dieser Wechsel wird in der Regel durch die Entnahme einzelner Stämme oder kleiner Baumgruppen herbeigeführt, wodurch Bestandslücken unterschiedlicher Größe geschaffen werden. Verschiedene Arbeiten berichten über die Einflüsse von Bestandslücken auf die Komponenten des Wasserhaushalts. Solche Einflüsse sind zum Beispiel eine Erhöhung des Bestandsniederschlags, eine verringerte Interzeption und Transpiration, aber auch eine erhöhte Evaporation (Marthews et al, 2008; Bartsch et al., 2002; Aboal et al., 2000; Bäumler et al., 1997; Hüser et al., 1996; Bauhus, 1994).

Ein forstwirtschaftlicher Eingriff, der zum eingangs erwähnten Wechsel von Nadelzu Laubbaumbeständen beitragen kann, aber in vielerlei Hinsicht ein Extrem darstellt, ist der Kahlschlag. Von verschiedenen Autoren konnte verdeutlicht werden, in welchem Umfang sich Kahlschläge auf die Komponenten des Wasserhauhalts auswirken. Solche Auswirkungen sind zum Beispiel eine Erhöhung der Evaporation sowie eine Verringerung der Transpiration und Interzeption, die zu einer insgesamt reduzierten Evapotranspiration führen sowie zu einem teilweisen Auftreten von Oberflächenabfluss, einem Anstieg der Bodenwassergehalte und der Grundwasserspende und letztendlich zu höheren Grundwasserspiegeln (Parfitt et al., 2002; De Keersmaeker et al., 2000; Fleming et al., 1997; Hüser et al., 1996; Dube et al., 1995; Likens et al., 1970). Darüber hinaus wurde in zahlreichen Studien aus unterschiedlichen Disziplinen gezeigt, wie sich der zeitlich und räumlich abrupte Übergang vom kahlgeschlagenen Gelände in den angrenzenden Bestand kleinräumig stark modifizierend auf stoffliche und energetische Umweltparameter sowie auf Reaktionen der Biota auswirkt (Kapos, 1993; Lewis, 1998; Didham. 1999; Didham et al. 1998a, 1998b; Carvalho and Vasconcelos, 1999; Lovejoy, 1986). An den 
Übergängen zwischen Bestand und Freifläche wird von graduellen Änderungen der abiotischen Umweltparameter berichtet (Camargo and Kapos, 1995). Insbesondere Niederschläge und Luftemperaturen (Radler et al., 2008) sowie die Bodentemperaturen und der Strahlungsinput ändern sich mit der Entfernung zum Bestandsrand und beeinflussen die Umweltbedingungen von Arealen der Freifläche und des Bestandes bis auf $60 \mathrm{~m}$ Entfernung von der Bestandsgrenze (vgl. Kapitel 3, Fröhlich et al., 2009a). Strahlung und Luftemperatur haben einen starken Einfluss auf die stomatären Leitfähigkeiten (Adams et al., 1991) und somit auf die Transpiration. Ferner wurden an den Rändern von Kahlschlägen höhere Dekompositionsraten festgestellt (Didham 1998c), was wiederum die Qualität des Sickerwassers beeinflussen kann (Katzensteiner, 2003). Für die Bilanzierung der Stofflüsse jedoch ist eine genaue und differenzierte Betrachtung des Bodenwasserhaushalts unbedingt erforderlich.

Studien zu Änderungen des Wasserhaushalts wurden vorwiegend im Zentrum von Kahlschlägen durchgeführt (vgl. Moore and Wondzell, 2005; Adams et al., 1991) oder Jahrzehnte nach Abholzung und anschließender Wiederaufforstung (Mäkitalo et al., 2004; Cienciala et al., 2002). Im Gegensatz dazu betrachtet die hier durchgeführte Studie die ersten Jahre direkt nach der Abholzung und bezieht explizit randliche Standorte ein.

Ziel der vorliegenden Arbeit war es, die nachfolgenden Hypothesen einer Überprüfung zu unterziehen und sie zu quantifizieren. Dazu wurden neben den Untersuchungen im Feld auch Modellrechnungen herangezogen.

- Auf Kleinkahlschlägen repräsentieren Messungen im Zentrum nicht das hydrologische Geschehen auf der Gesamtfläche.

- Der verbleibende Altbestand beeinflusst erhebliche Flächenanteile des Kleinkahlschlags, was sich nicht nur in der Verteilung der Niederschläge auswirkt sondern auch auf die Evapotranspiration und die Grundwasserspende.

- Auch der Altbestand wird in seinen Randbereichen hinsichtlich des Wasserhaushaltes beeinflusst.

- Daraus folgt, dass ein Kahlschlag hinsichtlich des Wasserhaushaltes nicht als Einheit angesehen werden kann, sondern einer räumlich und zeitlich differenzierten Betrachtung bedarf, was insbesondere eine Modifikation der Inputparameter gegenüber den Verhältnissen des Kahlschlagzentrums erfordert.

Des Weiteren soll die Anwendbarkeit des Modellsystems EXPERT-N (Priesack, 2006) auf forstwirtschaftlich genutzte Systeme geprüft werden. 


\subsection{Untersuchungsraum}

2003 wurde eine Fläche von 2 ha in einem 85-jährigen Fichtenreinbestand eingeschlagen. Mit einer zusammenhängenden Fläche von mehr als einem Hektar entspricht dies einem Kahlschlag im Sinne des Niedersächsischen Waldgesetzes (NWaldLg 2004). Das Waldgebiet befindet sich ca. 60 km nordwestlich Göttingens, an der Westabdachung des Solling Höhenzuges (Otterbach $51^{\circ} 46^{\prime}$ N., $9^{\circ} 27^{\prime}$ E.). Der Kahlschlag liegt $310 \mathrm{~m}$ über dem Meeresspiegel. Im Untersuchungszeitraum (2005-2007) lag die mittlere Lufttemperatur bei $9.2^{\circ} \mathrm{C}$ und der mittlere Jahresniederschlag bei $1028 \mathrm{~mm}$.

Der Boden entwickelte sich in einer umgelagerten Lößdecke mit einer Mächtigkeit von 60-90 cm, die Textur wird von der Kornfraktion Schluff dominiert (78-83 \%). Der Löß wird von einer stark verdichteten Fließerde unterlagert. Als Bodentyp wurde eine schwach podsolierte Braunerde (Dystric Cambisol) ausgewiesen. Die pH Werte sind niedrig und liegen zwischen 3.5 und 4.4, das C-N-Verhältnis liegt in 0-5 cm Tiefe um 20 und die Basensättigung erreicht knapp $11 \%$. Messwerte zur Bodenphysik und Bodenchemie sind in Tabelle 4-1 zusammengefasst.

Mit weniger als $3^{\circ}$ ist die Untersuchungsfläche schwach nach Nordosten geneigt. Bereits ab der ersten Vegetationsperiode nach dem Kahlschlag etablierten sich auf der Fläche Adlerfarn (Pteridium aquilinum, L.) und Brombeere (Rubus spp.) als dominante Arten.

Tabelle 4-1: Textur und bodenchemische Messwerte Austauschbare Kationen (AKE), Basensättigung (BS), C, N und C-N-Verhälniss und Lagerungsdichte (LD) in der Nähe der vier Intensivmessfelder am Kahlschlag Otterbach für 5 und $20 \mathrm{~cm}$ Tiefe.

\begin{tabular}{|c|c|c|c|c|c|c|c|c|c|c|c|}
\hline Messfeld & $\begin{array}{l}\text { Tiefe } \\
{[\mathrm{cm}]}\end{array}$ & Ton & $\begin{array}{l}\text { Schluff } \\
--[\%]-\end{array}$ & Sand & $\begin{array}{l}\text { AKE } \\
{\left[\mathrm{mmol} \mathrm{kg}^{-1}\right]}\end{array}$ & $\begin{array}{l}\text { BS } \\
{[\%]}\end{array}$ & C & $\begin{array}{l}\mathrm{N} \\
{\left[\mathrm{g} \mathrm{kg}^{-1}\right]}\end{array}$ & C/N & $\begin{array}{l}\mathrm{pH} \\
(\mathrm{H} 2 \mathrm{O})\end{array}$ & LD \\
\hline \multicolumn{12}{|c|}{ Altbestand (A) } \\
\hline & 5 & 11 & 82 & 7 & 84 & 12 & 62.5 & 3.0 & 21 & 3.6 & 0.3 \\
\hline & 20 & 14 & 80 & 6 & 34 & 10 & 15.2 & 1.0 & 15 & 4.4 & 1.0 \\
\hline & 60 & 12 & 83 & 5 & 62 & 11 & 5.0 & 0.4 & 13 & 4.3 & 1.2 \\
\hline \multicolumn{12}{|c|}{ Nordwestrand (B) } \\
\hline & 5 & 11 & 77 & 11 & 80 & 13 & 41.6 & 2.1 & 20 & 3.7 & 0.3 \\
\hline & 20 & 15 & 76 & 9 & 40 & 11 & 20.6 & 1.2 & 17 & 4.3 & 1.2 \\
\hline & 60 & 20 & 68 & 12 & 55 & 10 & 1.9 & 0.3 & 6 & 4.1 & 1.6 \\
\hline \multicolumn{12}{|c|}{ Kahlschlag (C) } \\
\hline & 5 & 11 & 80 & 9 & 80 & 10 & 42.6 & 2.2 & 19 & 3.5 & 0.4 \\
\hline & 20 & 14 & 79 & 7 & 32 & 11 & 14.4 & 1.0 & 14 & 4.2 & 1.3 \\
\hline & 60 & 17 & 74 & 9 & 45 & 12 & 3.0 & 0.3 & 10 & 4.2 & 1.6 \\
\hline \multicolumn{12}{|c|}{ Suedwestrand (D) } \\
\hline & 5 & 14 & 77 & 9 & 93 & 12 & 27.8 & 1.5 & 19 & 3.9 & 0.4 \\
\hline & 20 & 14 & 78 & 8 & 45 & 10 & 7.0 & 0.5 & 14 & 4.4 & 1.4 \\
\hline & 60 & 15 & 78 & 7 & 60 & 10 & 2.3 & 0.2 & 11 & 4.3 & 1.6 \\
\hline
\end{tabular}

\subsection{Material und Methoden}

Vier Messfelder wurden zur kontinuierlichen und automatischen Erfassung der Matrixpotentiale und Bodentemperaturen eingerichtet. Diese Stationen befanden sich im Altbestand (A), am Nordwestrand des Kahlschlags unmittelbar hinter der 
Baumkronenlinie (B), etwas versetzt zum geometrischen Zentrum auf der Freifläche des Kahlschlags (C) und am Südwestrand des Kahlschlages (D) in einem Abstand von ca. $10 \mathrm{~m}$ zur Baumkronenlinie des angrenzenden Bestandes. Des Weiteren wurden meteorologische Größen an Referenzmessfeldern in Zentrum des Kahlschlags und im Altbestand sowie entlang von vier Transekten an den Kahlschlagrändern gemessen. Die Anordnung der Messfelder ist in Abbildung 4-1 wiedergegeben.

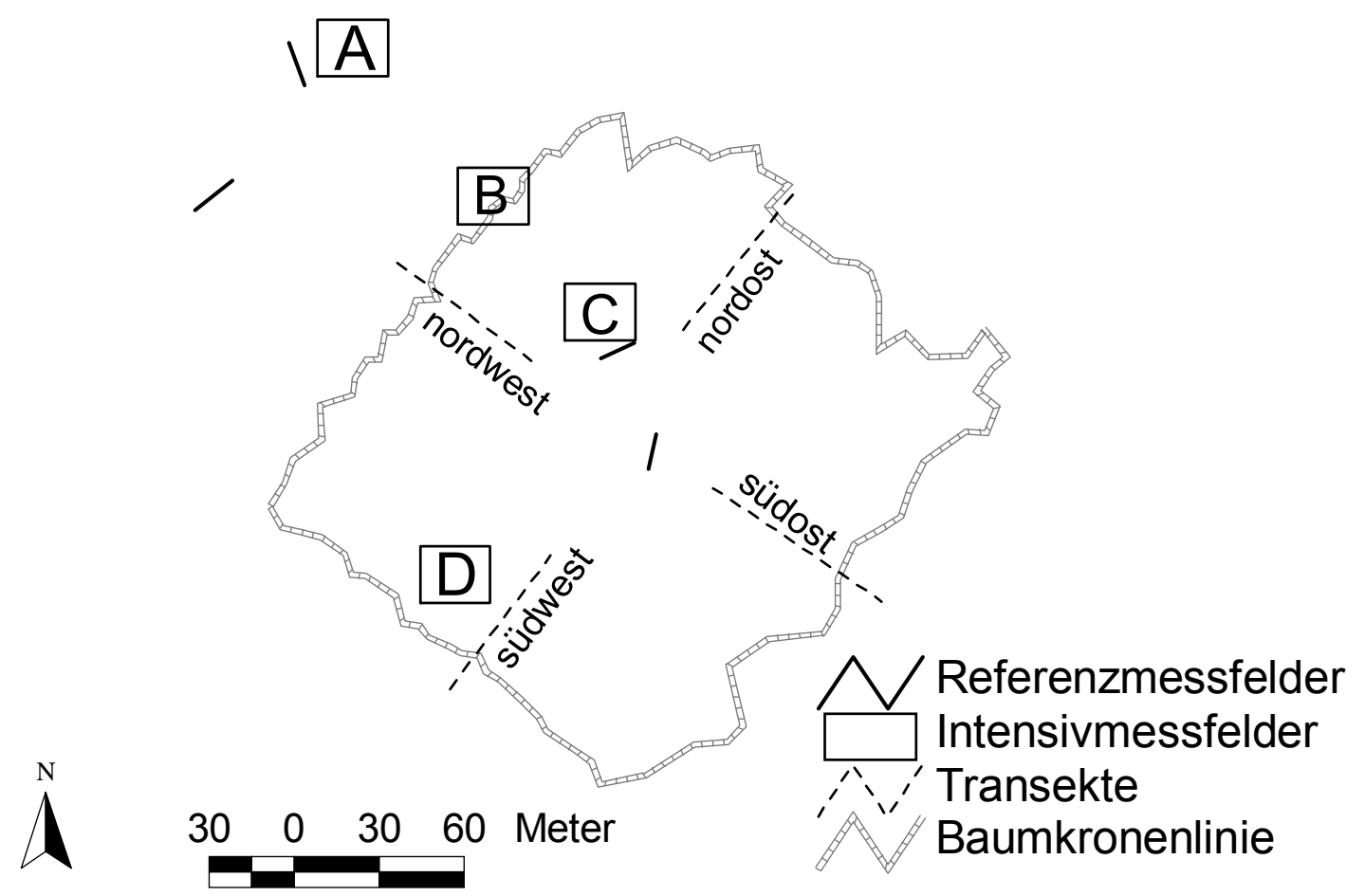

Abbildung 4-1: Plan der Messanordnung des Kahlschlags Otterbach im Solling.

Vor der Einrichtung der Intensivmessfelder wurden an je einem Profil pro Station Bodenproben zur Analyse chemischer und physikalischer Eigenschaften genommen. Die Matrixpotentiale wurden mit Tensiometern gemessen, die mit PC2G Druckaufnehmern der Fa. Honeywell ausgestattet sind. Die Druckaufnehmer wurden vor ihrer Installation im Labor kalibriert. Ihre Energieversorgung war mit einer zentralen Solaranlage sichergestellt. An jeder Station waren jeweils 6 Tensiometer in den Tiefen 20 und $60 \mathrm{~cm}$ installiert. Nach ihrem Einbau wurde der Boden um die Schäfte leicht kompaktiert. Enganliegende Silikonscheiben verhinderten, dass ein Abfluss an den Rohren die Messergebnisse verfälschte. An diesen Stationen wurden auch Lufttemperaturen in Bodennähe gemessen.

Eine Wetterstation nahe dem Kahlschlagzentrum registrierte zeitlich hoch aufgelöst Globalstrahlung, Lufttemperatur, Niederschläge, relative Luftfeuchte sowie die Windgeschwindigkeiten. Des Weiteren wurden im Altbestand sowie an den Rändern vor 
und hinter der Baumkronenline die Niederschläge erfasst (Abb 4-1). Näheres zu den technischen Details der meteorologischen Messeinrichtungen findet sich bei Radler et al. (2008).

Die klimatologischen und bodenphysikalischen Messwerte wurden mit dem Statistikpaket R (R Core Team 2005) zu Tagesmittelwerten weiterverarbeitet, diese dienten als Eingangsgrößen für die Modellierung. Die Komponenten des Wasserhaushalts wurden mit dem modularen Modellpacket Expert-N 3.0 (Priesack, 2006) berechnet, die Modellkonfiguration ist in Tabelle 4-2 zusammengestellt.

Tabelle 4-2: Modellkonfiguration im Modellsystem Expert-N zur Wasserhaushaltsmodellierung der Ökotope des Kahlschlags Otterbach

$\begin{array}{ll}\begin{array}{l}\text { Evaporation und Transpiration } \\ \text { Potentielle Evapotranspiration }\end{array} & \text { Penman-Monteith (FAO) } \\ \text { Potentielle Evaporation } & \text { Crop Cover Factor } \\ \text { Aktuelle Evaporation } & \text { Limited Flux Rate } \\ \text { Interception } & \text { Gash (Gash et al., 1978) } \\ \text { Bodenwasser } & \\ \text { Transport } & \text { Richards Gleichung } \\ \text { Hydraulische Funktionen } & \text { van Genuchen und Mualem (1980) } \\ \text { Randbedingungen } & \text { SCS CN (inklusive Hangneigung) } \\ \text { Oberflächenabfluss } & \text { Schneeakkumulation und -schmelze mit Wind } \\ \text { Schnee } & \text { freie Drainage } \\ \text { Untere Randbedingung } & \\ \text { Pflanze-Wasser-Beziehung } & \text { Crop cover Factor (LEACHN) } \\ \text { Wasserbedarf (potentielle Transpiration) } & \text { Feddes (SWATRE) } \\ \text { Wasseraufnahme } & \text { de Vries (2001) \& Hörmann et al. (2003) } \\ \text { Wurzelverteilung } & \end{array}$

Die Humusauflagen und der Mineralboden wurden als eigene Kompartimente mit dem Richardsansatz modelliert. Aus den Humusauflagen $(\mathrm{H})$ und dem Mineralboden in den Tiefen 0-5, 20-25, 60-65 und 80-85 cm wurden an jeder Station 6 Stechzylinderproben gewonnen, an welchen im Labor die Wasserspeicher Funktionen ermittelt wurden und woran anschließend die Pedotransferfunktionen nach van Genuchten (1980) angepasst wurden.

Interzeptionsverlust und Benetzungskapazität des Altbestandes wurden anhand der Messungen zwischen August 2004 und Mai 2007 als Mittelwert aller Tage bestimmt, an denen Niederschlag zu verzeichnen war und die Messerfassung mindestens $95 \%$ betrug $(n=259)$. Auf die gleiche Weise wurde am Nordwestrand $(n=202)$ verfahren. Die Regression der Bestandsniederschläge für den Altbestand und den Nordwestrand wurde mittels der kleinste-Quadrate-Methode nach Gauss-Newton in $\mathrm{R}$ an Formel 4-1 angepasst und ihr nichtlinearer Korrelationskoeffizient berechnet (vgl. Sachs und Hedderich, 2006). Diese Funktion ist geeignet zur Beschreibung der Niederschlagsbeziehungen, da sie durch den Ursprung verläuft und in einen nahezu geraden Teil übergeht. Der Schnittpunkt der Abszisse mit einer Geraden, die parallel zur 1:1-Linie verschoben wurde, stellt die Benetzungskapazität dar. 


$$
B=a F^{b} * e^{c F}
$$

$B$ : Bestandsniederschlag

$a, b, c$ : Koeffizienten, mit $a, c \neq 0$ und $0<b<1$

e: Exponentialfunktion

$F$ : Freilandniederschlag

Benetzungskapazitäten für die Vegetation wurden aus der Literatur entnommen (Breuer et al., 2003) und mit den angegebenen Parametern für das Gashmodell (Gash et al., 1978) bei de Vries et al. (2001) angepasst. Fehlende meteorologische Daten wurden je nach Verfügbarkeit mit Werten der nächstgelegenen Wetterstation ergänzt.

Gesättigte hydraulische Leitfähigkeiten für jedes der vier Bodenprofile wurden aus der Literatur entnommen (Forstliche Kartieranleitung, 2003), gemäß den texturellen Beschaffenheiten und der Lagerungsdichten. Bei der Wurzelverteilung, die mit einer exponentiellen Abnahme gemäß den Empfehlungen bei de Vries et al (2001) und Hörmann et al (2003) implementiert wurde, fanden die Eindringwiderstände des Bodens um die Stationen Beachtung. Die Eindringwiderstände waren mit einem Penetrometer der Fa. Eijkelkamp (Niederlande) in 8-facher Wiederholung in der Nähe jeder Station aufgenommen worden. Als untere Grenze für die Durchwurzelbarkeit wurde der Grenzwert von 3 MPa Eindringwiderstand gewählt.

Der Bedeckungsgrad des Altbestandes wurde aus Luftbildaufnahmen geschätzt (95\%) für den Übergang Bestand-Kahlschlag mit $65 \%$ veranschlagt und für die Freiflächen angepasst (Winter $2 \%$, Sommer 3-5\%). Als Beginn und Ende der Vegetationszeiten wurden für jedes Jahr die Termine eingesetzt, ab welchen die Lufttemperaturen in Bodennähe $5{ }^{\circ} \mathrm{C}$ dauerhaft über- oder unterschritten.

Für jeden Standort der Intensivmessfelder wurde das Modell parametrisiert, um die verschiedenen Bereiche auf und um den Kahlschlag darzustellen. Für Vergleiche wurden am Nordwestrand (B) jeweils eine Simulation mit den im Zentrum des Kahlschlags gemessenen meteorologischen Variablen durchgeführt (Simulation I) und eine Simulation mit erhöhtem Strahlungsaufkommen (Simulation II), der den zusätzlichen lateralen Energieeinfall berücksichtigen sollte. Am Südwestrand (D) hingegen wurde eine Simulation mit den im Zentrum gemessenen zeitabhängigen Variablen durchgeführt (Simulation III) sowie ein Durchlauf (Simulation IV) mit modifizierten Strahlungs- und Niederschlagsaufkommen. Die modifizierten Strahlungswerte wurden entsprechend den Angaben in Kapitel 3 (Fröhlich et al., 2009a; Panferov et al. 2001) eingesetzt, aus welchen für den Nordwestrand (B) eine gegenüber dem Bestandsinneren (A) erhöhte Strahlung von 183-680 \% abgeleitet wurde. Die Strahlungsreduktion für den Südwestrand (D) schwankte hingegen zwischen 33 und 77 Prozent gegenüber dem Kahlschlagzentrum als Bezugspunkt. Der jahreszeitliche Verlauf wurde jeweils entsprechend berücksichtigt. 
Als Parameter für die Wasseraufnahme von Wurzeln nach dem Modell von Feddes et al. (1974) wurden Matrixpotentiale entsprechend den Ergebnissen von Benecke (1984) für den Fichtenstandort im Solling eingesetzt, da auch die Bodenbedingungen vergleichbare Eigenschaften aufweisen. Das Matrixpotential oberhalb dessen die Wasseraufnahme aufhören sollte lag bei $-40 \mathrm{hPa}$, dasjenige unterhalb dem die Wasseraufnahme begann optimal zu werden bei $-125 \mathrm{hPa}$, das Matrixpotential unterhalb dem die Wasseraufnahme aufhört optimal zu sein bei $-2500 \mathrm{hPa}$ und schließlich das Matrixpotential unterhalb dem die Wasseraufnahme ganz stoppen sollte bei $-15500 \mathrm{hPa}$.

Zur Kalibrierung und Validierung der Modellergebnisse wurden mit Formel 4-2 der Modell-Effizienz-Index (modelling effeciency index, IA) nach Willmott (1982) und die normierte Quadratwurzelabweichung (NRMSE) mit Formel 4-3 nach Wallach und Goffinet (1989) berechnet. Während der Parametrisierung war das Ziel, diese Indices zu verbessern. Als Kalibrierungsphase diente die Periode zwischen Januar und September 2006, da in diesem Zeitraum eine hohe Dynamik in den Bodenmatrixpotentialen zu verzeichnen war.

$$
\begin{gathered}
\text { IA }=1-\frac{\sum_{i=1}^{n}\left(P_{i}-O_{i}\right)^{2}}{\sum_{i=1}^{n}\left(\left|P_{i}-\bar{P}\right|\right)+\left(\left|O_{i}-\bar{O}\right|\right)^{2}} \\
\text { NRMSE }=\frac{1}{\bar{O}} \sqrt{\frac{\sum_{i=1}^{n}\left(P_{i}-O_{i}\right)^{2}}{n}} \\
P_{i}: \text { simulierte Werte } \\
\bar{P}: \text { Mittelwert aus } P_{i} \\
O_{i}: \text { gemessene Werte } \\
\bar{O}: \text { Mittelwert aus } O_{i}
\end{gathered}
$$

\subsection{Ergebnisse und Diskussion}

\subsubsection{Randbedingungen}

\subsubsection{Interzeption}

Der Interzeptionsverlust für den Altbestand der Fläche Otterbach lag bei $32 \%$ und derjenige für den Bestand am Nordwestrand des Kahlschlags bei 25 \%. Diese Zahlen liegen innerhalb der Spannbreite von 10-30 \% Verminderung des Kronendurchlasses (Moore and Wondzell, 2005) für Koniferen im Pazifischen Nordwesten der USA und denjenigen für Fichtenaltbestände im Hochsolling $33 \%$ (Benecke, 1978) und $30 \%$ (Eckersten, 1995). Die über die Anpassung nach Formel 4-1 bestimmten Benetzungskapazitäten im Altbestand und am Nordwestrand liegen mit 6.0 und $4.9 \mathrm{~mm}$ vergleichsweise hoch (siehe Abbildung 4-4 und 4-5). 
Breuer et al. (2003) geben für 80-90-jährige Fichten (Picea abies) eine Benetzungskapazität von 4.0-4.7 mm an und zitieren als Extremwerte für Koniferen $9.0 \mathrm{~mm}$. Ein Wert von $4.7 \mathrm{~mm}$ wurde übereinstimmend für 90 -jährige Fichtenbestände in den Hochlagen des Sollings (> $500 \mathrm{~m}$ ü. NN) gefunden (Benecke et al., 1978). Der vorliegende Wert von $6.0 \mathrm{~mm}$ liegt zwar innerhalb der Spanne, die für Koniferen angegeben wird, aber deutlich über den Werten, die im Hochsolling ermittelt wurden. Die hier untersuchte Fläche liegt jedoch über $200 \mathrm{~m}$ tiefer als diejenige des Hochsollings und besitzt eine nach Nordwesten geneigte Exposition, was sich in einer höheren Interzeptionsevaporation ausdrücken kann. Ferner fielen in zwei Jahren des Beobachtungszeitraums im Vergleich zum langjährigen Mittel (1090 mm) außergewöhnlich geringe Jahresniederschläge (851 und 896 mm). Die eingehenden Niederschlagsereignisse sind daher nicht repräsentativ für längere Zeiträume in der Region. Da die Modellierung des Wassertransfers um den Zeitraum liegt, in dem die Werte für die Benetzungskapazität abgeleitet wurden, und die Korrelationskoeffizienten für die Funktionen an beiden Straten jeweils mit 0.96 sehr hoch liegen, stellen die ermittelten Werte verlässliche lokale Parameter dar. Auch die Verringerung der Benetzungskapazität und des Interzeptionsverlustes sind aufgrund der Randlage, das heißt einer stark erhöhten lateralen Wegsamkeit, plausibel. Ein weiterer Effekt, der zu geringeren Benetzungskapazitäten geführt haben mag, ist ein stärkerer Nadelund Astverlust der randständigen Bäume während der Herbst- und Frühjahrsstürme.

Während innerhalb der Vegetationsperiode sowohl das Gash-Modell als auch der empirische Ansatz Ergebnisse liefern, die innerhalb eines $95 \%$ Konfidenzintervalls liegen, wird während der Wintermonate der Interzeptionsverlust mit dem empirischen Ansatz überschätzt (Tab. 4-4). Jedoch werden auch mit dem Gash-Modell außerhalb der Vegetationszeit Fehleinschätzungen erzielt, die leicht außerhalb des Konfidenzbereichs liegen (Tab. 4-4).

Die Auswertung für das Freiland ergab eine Benetzungskapazität von $1.3 \mathrm{~mm}$, einen Kronenschluss von $77 \%$ und einen Wert von 0.22 für das von 1 subtrahierte Verhältnis der durchschnittlichen täglichen Evaporation während eines Niederschlags $\left(E_{a}\right)$ zum durchschnittlichen täglichen Niederschlag $\left(R_{a} ; 1-R_{a} / E_{a}\right)$. 


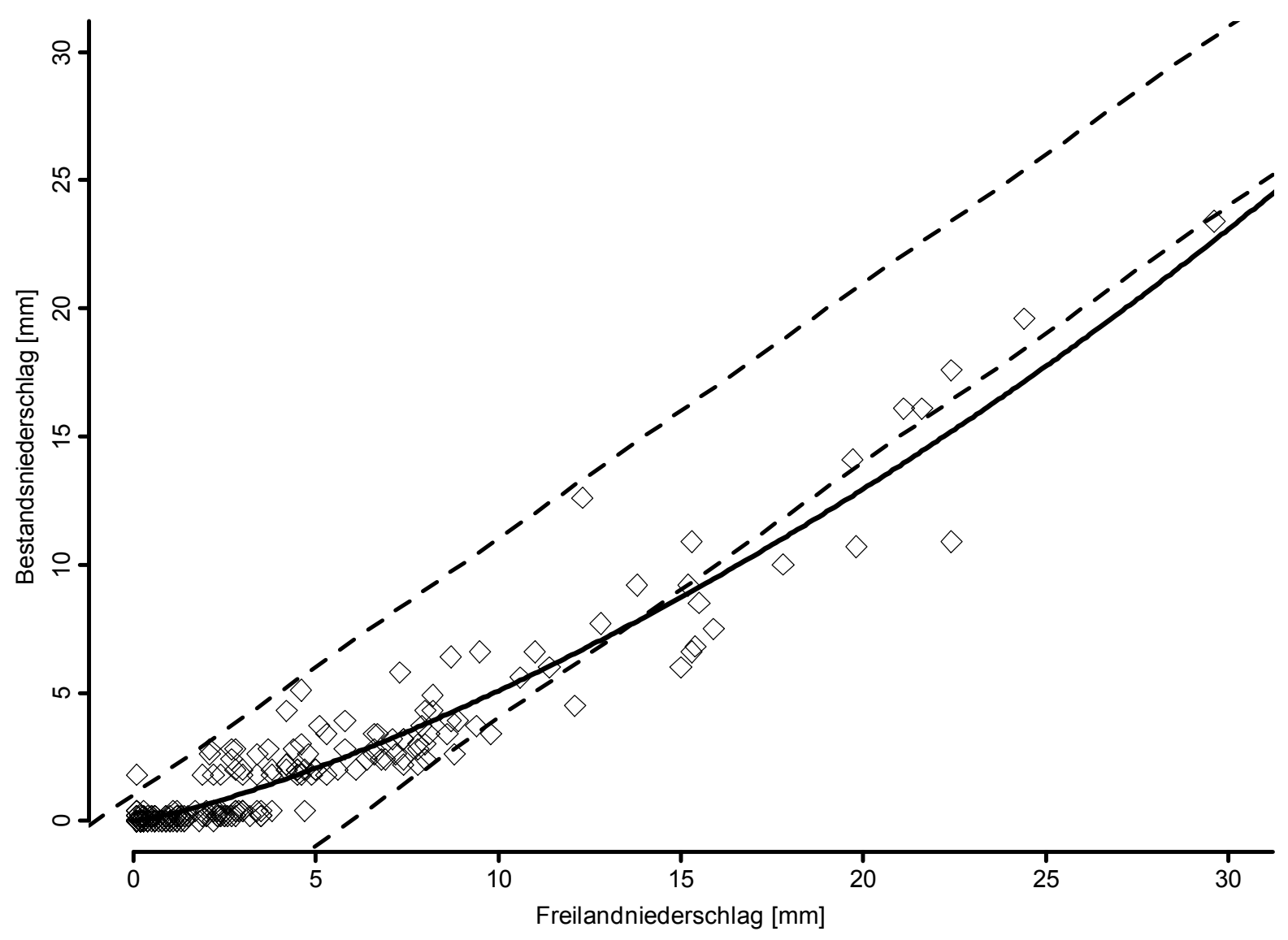

Abbildung 4-2: Benetzungskapazität des Altbestandes. Durch Anpassung nach Formel 4-1 wurde die Benetzungskapazität durch eine parallele Verschiebung zur 1:1-Linie gewonnen (unterbrochene Linien).

Ursachen für diese Mängel könnten in der unrealistischen Annahme einer konstanten Benetzungskapazität liegen. Für eine differenziertere Annahme der Benetzungskapazität sprechen ihre Abhängigkeit von der Windgeschwindigkeit und die Entkoppelung des Sättigungsdefizits der Luft im Kronenraum von der Evaporation (Klaasen et al., 1996).

Tabelle 4-3: Bilanz des Bestandsniederschlages für die Vegetationsperiode und im Winter unter Altbestand und unter Krone am Nordwestrand des Kahlschlages

\begin{tabular}{|c|c|c|c|c|c|}
\hline \multirow{3}{*}{\multicolumn{2}{|c|}{ Freilandniederschlag $[\mathrm{mm}]$}} & \multicolumn{4}{|c|}{--ostandsniederschlag [mm] } \\
\hline & & \multirow{2}{*}{\multicolumn{2}{|c|}{$\begin{array}{l}\text {--- Modell ---- } \\
\text { Gash empirisch }\end{array}$}} & \multirow{2}{*}{\multicolumn{2}{|c|}{$\begin{array}{l}\text {--ossung ---- } \\
\text { Mittelwert } 1.5^{\star} \text { Standardabw. }(\mathrm{n}=6)\end{array}$}} \\
\hline & & & & & \\
\hline \multicolumn{6}{|c|}{ Sommer (11.05.05-20.09.05) } \\
\hline Altbestand & 349.8 & 228.0 & 182.9 & 199.9 & 28.4 \\
\hline Nordwestrand & 349.8 & 235.3 & 244.4 & 238.8 & -- \\
\hline \multicolumn{6}{|c|}{ Winter (16.11.05-25.01.06) } \\
\hline Altbestand & 110.9 & 100.7 & 47.4 & 73.6 & 15.3 \\
\hline Nordwestrand & 110.9 & 103.8 & 71.1 & 124.9 & -- \\
\hline
\end{tabular}




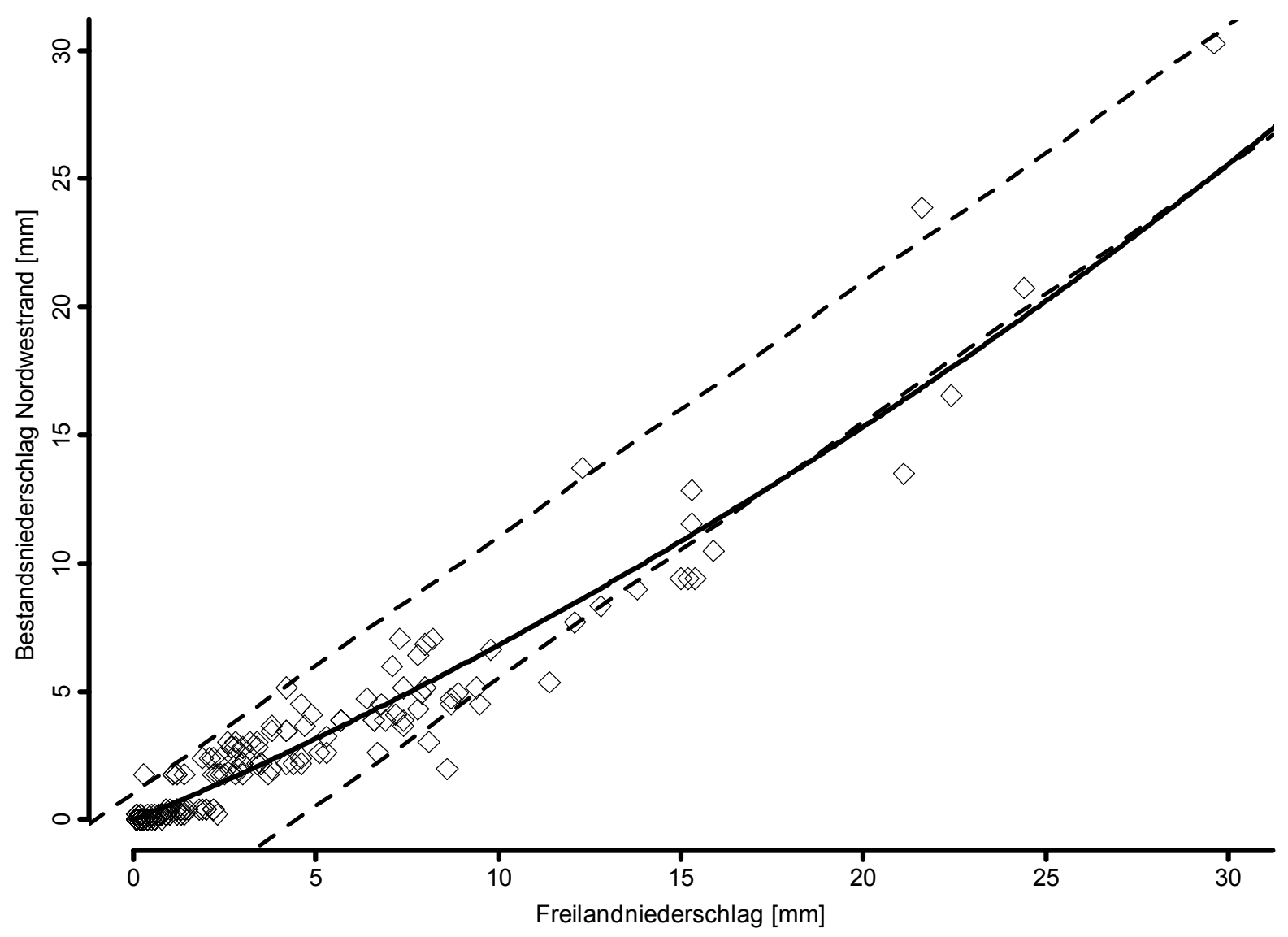

Abbildung 4-3: Benetzungskapazität des Bestandsrands. Durch Anpassung nach Formel 4-1 wurde die Benetzungskapazität am nordwestlichen Bestandsrand (B) durch eine parallele Verschiebung zur 1:1-Linie gewonnen (unterbrochene Linien).

\subsubsection{Bodenphysikalische Größen}

Abbildung 4-3 zeigt die mittleren Eindringwiderstände um die Messfelder im Bestand, am Nordwestrand und im Kahlschlagzentrum. Der Verlauf am Südwestrand entspricht demjenigen des Kahlschlags und ist aus Gründen der Übersichtlichkeit ebenso wie die Standardabweichungen der Kontrolle nicht dargestellt. Der Anstieg des Eindringwiderstands erfolgt im Bestand $(A)$ etwas kontinuierlicher und erst zwischen 70 und $75 \mathrm{~cm}$ Tiefe wird durch die Eindringwiderstände eine stark verdichtete Basislage angezeigt, während diese am Nordwestrand (B) bereits zwischen 50 und $60 \mathrm{~cm}$ erreicht wird. Die gefundenen Verläufe der Eindringwiderstände weisen gute Übereinstimmungen mit dem Muster auf, das Grunwald et al. (2001) für geschichtete Lössböden über glazialem Geschiebe zeigen und verdeutlichen die Unterschiede in den Mächtigkeiten der Lößlagen zwischen den Standorten. Dieser schlägt sich auch in den Ergebnissen der Texturanalysen zum Beispiel mit einer Abnahme des Schluff- zugunsten des Tonanteils am Nordwestrand (B) nieder (Tabelle 4-1). Die Eindringwiderstände wurden zur Parametrisierung der Durchwurzelung herangezogen, da hohe Eindringwiderstände einer weiteren 
Ausdehnung des Wurzelwerks entgegenwirken (Bowen, 1976.). Bei einem mittleren Eindringwiderstand von $3 \mathrm{MPa}$ sollte die Durchwurzelung aufhören, da direkte Abhängigkeiten der Wurzelentwicklung von Baumarten zu dieser Größe gefunden wurden (Sinett et al., 2008).

Die van-Genuchten-Parameter aus den Desorptionsreihen sind für alle vier Messfelder in Tabelle 4-4 angegeben.

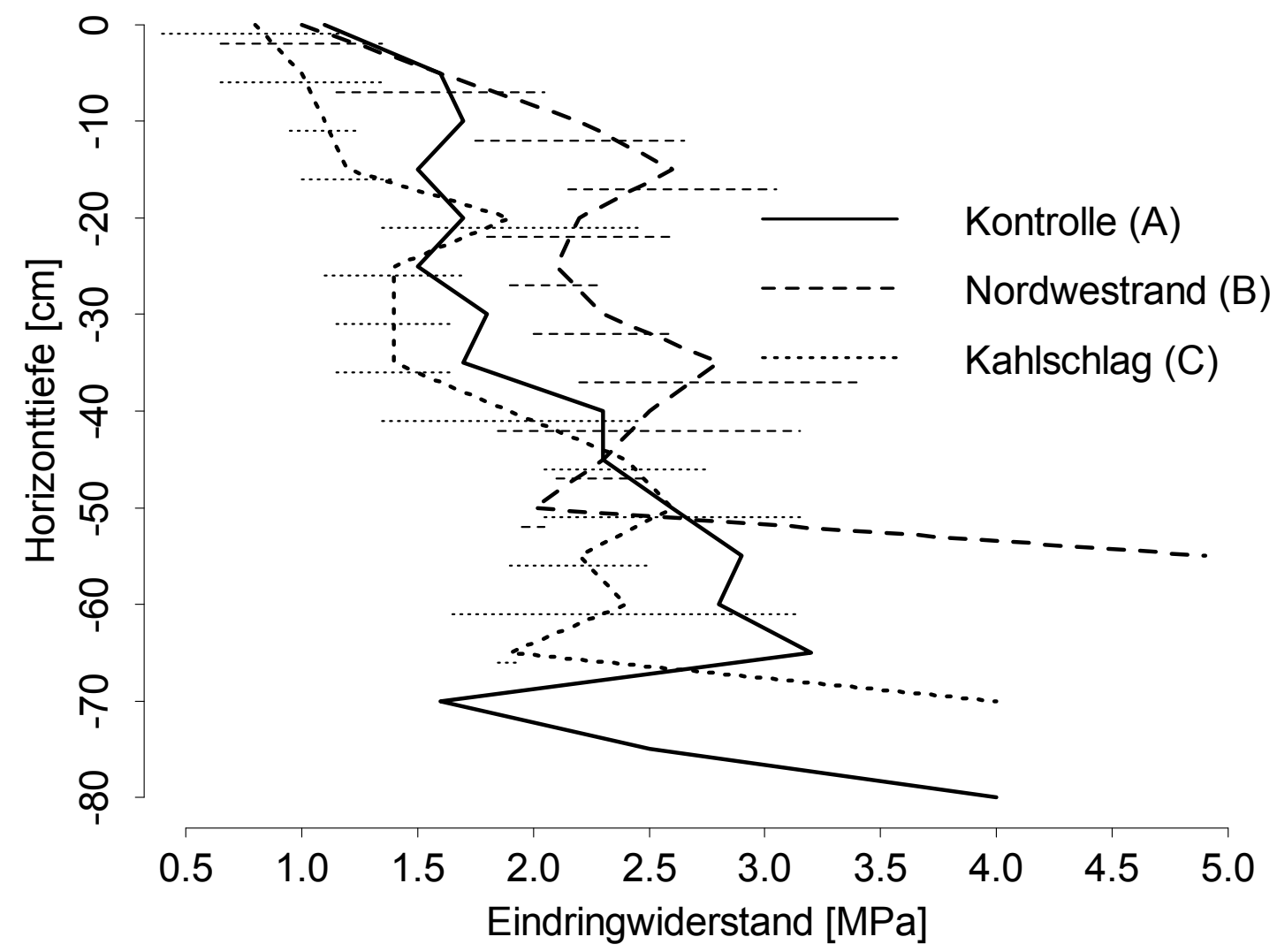

Abbildung 4-4: Eindringwiderstände des Bodens auf der Versuchsfläche Otterbach im Solling inn Mega Pascal. Dargestellt sind die Eindringwiderstände und ihre Standardabweichungen $(n=8)$ um die Stationen im Bestand (A) sowie am Nordwestrand (B) und auf dem Kahlschlag (D).

Tabelle 4-4: Parameter der Pedotransferfunktionen nach van Genuchten für die fünf Simulationsschichten

\begin{tabular}{rllrr} 
Tiefe & $\mathrm{n}$ & alpha & theta-r & theta-s \\
\hline $\mathrm{H}$ & 1.1245 & 2.9717 & 0 & 0.895 \\
$0-15$ & 1.2870 & 0.0150 & 0 & $0.547-0.695$ \\
$15-40$ & 1.2650 & 0.0231 & 0 & $0.408-0.625$ \\
$40-70$ & 1.1760 & 0.0296 & 0 & $0.408-0.555$ \\
$70-95$ & 1.0492 & 0.0659 & 0 & $0.367-0.387$ \\
\hline
\end{tabular}

\subsubsection{Messungen der Matrixpotentiale}

Zwischen 1. September 2005 und 31. Dezember 2007 lag an insgesamt 17 Tagen der Tagesmittelwert der Tensiometersaugspannungen im Altbestand unter $-600 \mathrm{hPa}$. Diese 17 Tage traten als ein einziges Intervall auf. Am Nordwestrand waren es im selben Bezugszeitraum 43 Tage, an denen dieser Grenzwert unterschritten wurde. Diese 43 Tage teilten sich am Nordwestrand in drei Intervalle auf. Eines davon trat 
zeitgleich mit der eingangs erwähnten 17-tägigen Periode des Altbestands auf. Dieser Zeitabschnitt dauerte jedoch am Nordwestrand insgesamt 6 Tage länger und wies eine leichte Verschiebung im Vergleich zum Altbestand auf (Beginn 8 Tage früher, Ende 2 Tage früher).

Matrixpotentiale von unter $-600 \mathrm{hPa}$ zeigen den Eintritt einer Wasserstressphase für Fichten an, wie die Beobachtungen von von Wilpert (1990) über den Beginn von nachweisbaren Zellveränderungen an Fichten im Schwarzwald zeigten. Ferner wurde die Reduktion des Verhältnisses von potentieller zu aktueller Transpiration ab ca. -600 hPa von Salihi (1984) an Fichten im Solling beobachtet. Die Messwerte lassen daher auf einen erhöhten Trockenstress, dem die Bäume am Nordwestrand unterliegen, schließen.

Im Gegensatz zum umgebenden Bestand ist es auf der Kahlschlagfläche nicht eine eingeschränkte Bodenwasserverfügbarkeit, die den Pflanzen Stress bereitet, sondern eine hoch gesättigte Bodenmatrix, die aufgrund von Sauerstoffmangel die Wurzelrespiration einschränkt und ein weiteres Wurzelwachstum limitiert. Insgesamt wurden zwischen 2005 und 2007 im Zentrum des Kahlschlags an 148 Tagen und am Südwestrand an 270 Tagen Matrixpotentiale über -10 hPa beobachtet. In der Hälfte der Zeit herrschten am Südwestrand damit nahezu gesättigte Bedingungen, welche vielen Baumarten erhebliche Schwierigkeiten bereiten ein tiefer reichendes Wurzelwerk auszubilden bzw. bereits vorhandene Wurzeln schädigen. Diese Werte sprechen für einen zumindest in seiner physiologischen Wirkung auf die Vegetation differenzierteren Wasserhaushalt auf kleinen Freiflächen. Der Grenzwert für den Beginn der Wasseraufnahme bei Fichten läge gemäß der Parametrisierung auf der Grundlage von Benecke (1984) bei $-39 \mathrm{hPa}$. Der hier angesetzte Grenzwert von -10 hPa ist somit bereits konservativ gewählt.

\subsubsection{Modellergebnisse und Vergleich}

An den peripheren Lagen des Bestandes wurden Änderungen der Randbedingungen festgestellt und sowohl am Rand des Bestandes als auch des Kahlschlags wiesen Beobachtungen auf eine Erhöhung des Stressfaktors Bodenwasser hin. Dies erforderte eine differenziertere Betrachtung der Standorte. Die Überprüfung der Modifikationen der atmosphärischen Randbedingungen erfolgt anhand eines Vergleichs der Simulationsläufe der Wasserhaushaltsmodelle. 
Tabelle 4-5: Mittlere normierte Quadratwurzelabweichung (Normalised root mean square error, NRMSE) und Modell-Effizienz-Index (Modelling effeciency index, IA) angegeben für Matrixpotentiale und die abgeleiteten Wassergehalte an den vier Straten

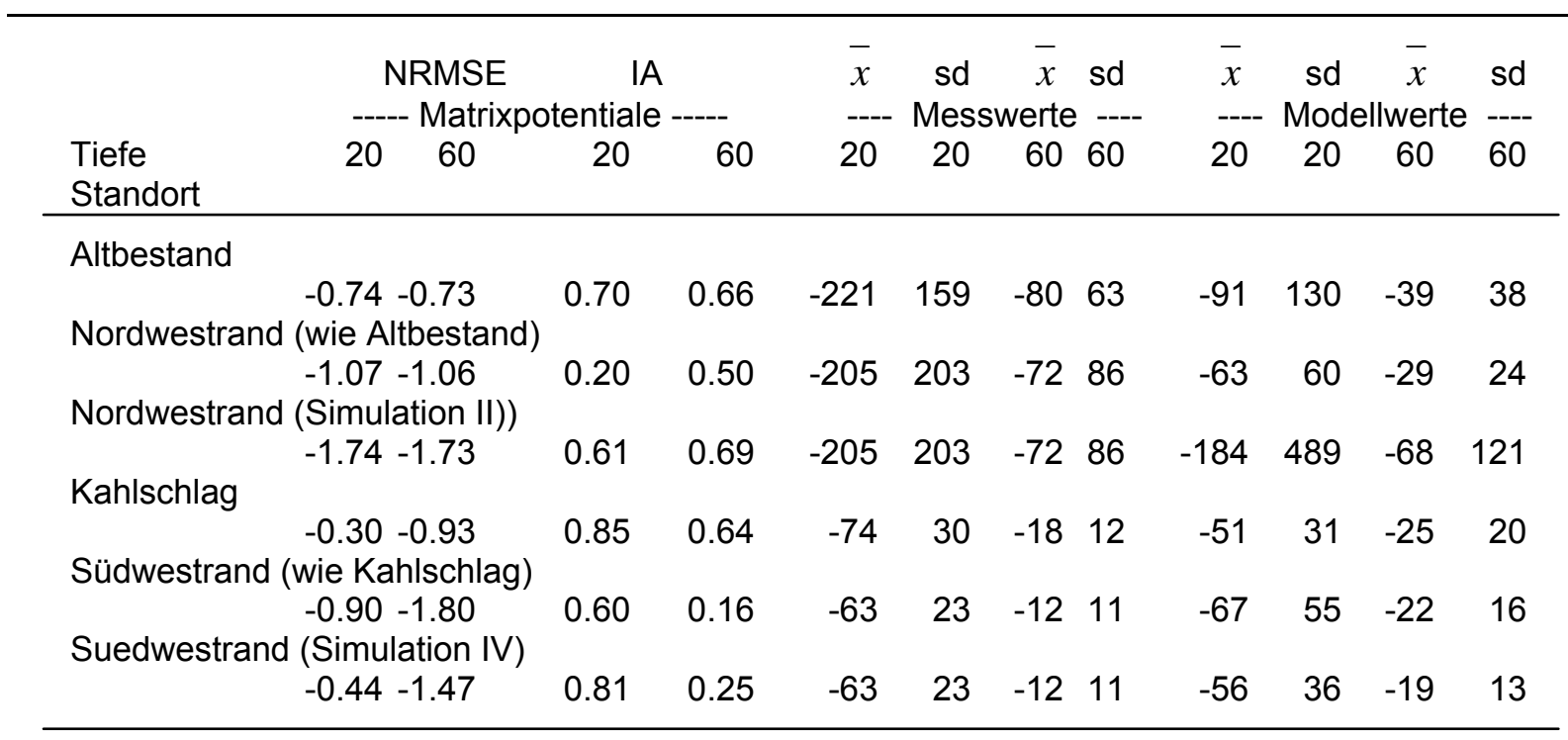

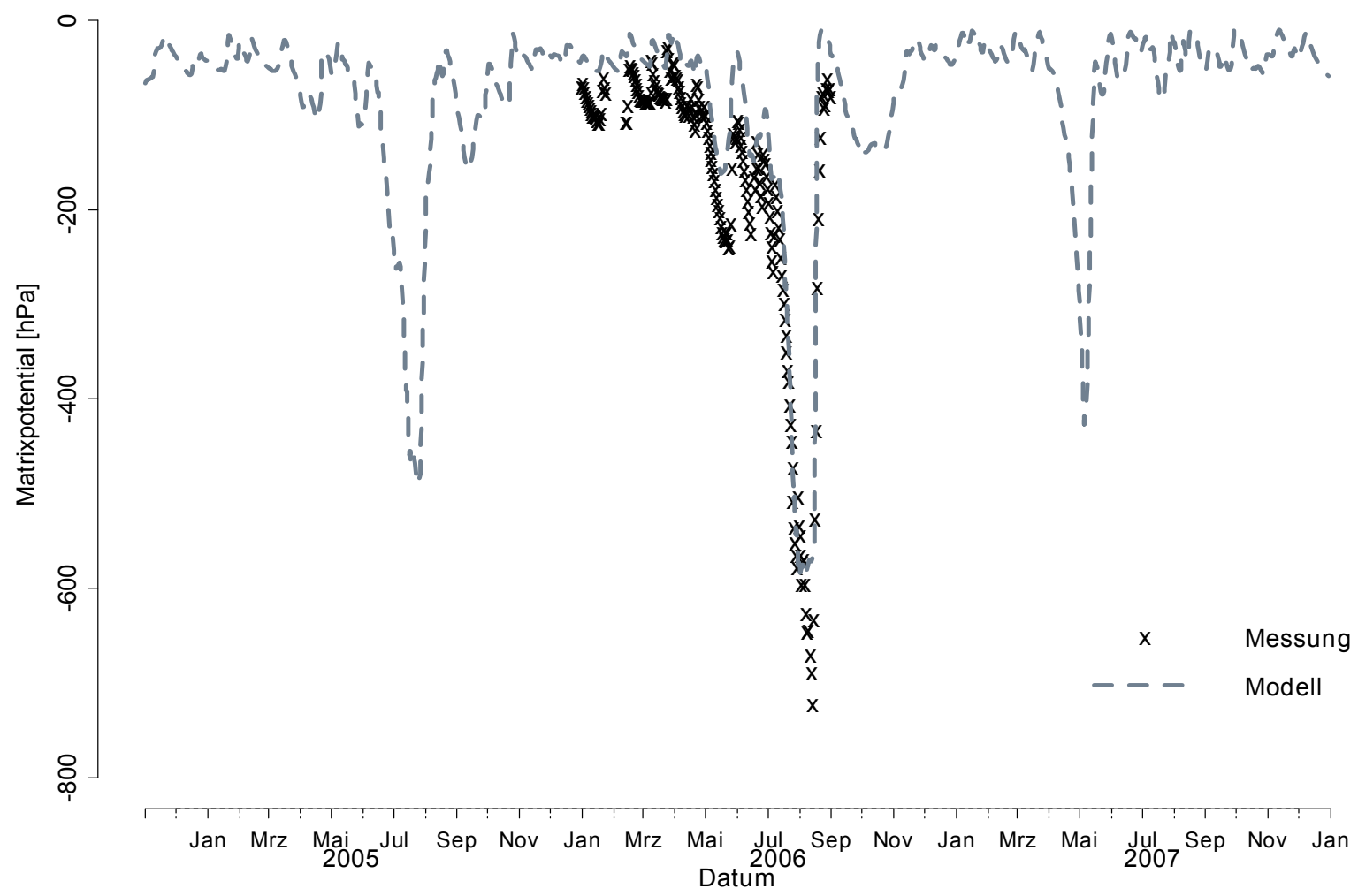

Abbildung 4-5: Bodenmatrixpotentiale in $20 \mathrm{~cm}$ Tiefe im Altbestand der Versuchsfläche Otterbach. Dargestellt sind die Modellergebnisse für den gesamten Untersuchungszeitraum und die Messwerte für den Kalibrierungszeitraum 1.1.2006-31.8.2006 
In Tabelle 4-5 sind die Modell-Effizienz-Indices (IA) und die normierten mittleren Quadratwurzelabweichungen (NRMSE) sowie Mittelwerte und Standardabweichungen der modellierten und gemessenen Matrixpotentiale für die Tiefen 20 und $60 \mathrm{~cm}$ aufgelistet. Als erste Validierung dienen die Mittelwerte und Standardabweichungen der Modellergebnisse und der Messwerte. Die Standardabweichungen sollten in der Regel mit zunehmender Schichttiefe kleiner werden, da die Variabilität der Bodenmatrixpotentiale mit der Tiefe und dem Sättigungsgrad des Bodens abnimmt (vgl. von Wilpert, 1990). Dies war auch durchweg der Fall (Tabelle 4-5). Als weitere Maßzahl zur Validierung dient der Modell-Effizienz-Index (IA), welcher Werte zwischen 0 und 1 annehmen kann und mit steigenden Werten eine höhere Modelleffektivität anzeigen soll. Die erzielten Modell-Effizienz-Indices liegen zwischen 0.20 und 0.85 und bewegen sich damit im Rahmen dessen, was auch durch frühere Bodenwasserhaushaltsmodellierungen erzielt wurde. So wurden Modell-Effizienz-Indices zwischen 0.34-0.92 unter Kiefernbestand (Wegehenkel und Jochheim, 2003) bzw. 0.10-0.75 für die Modellierung von Matrixpotentialen unter landwirtschaftlichen Kulturen erreicht (Wegehenkel, 2005).

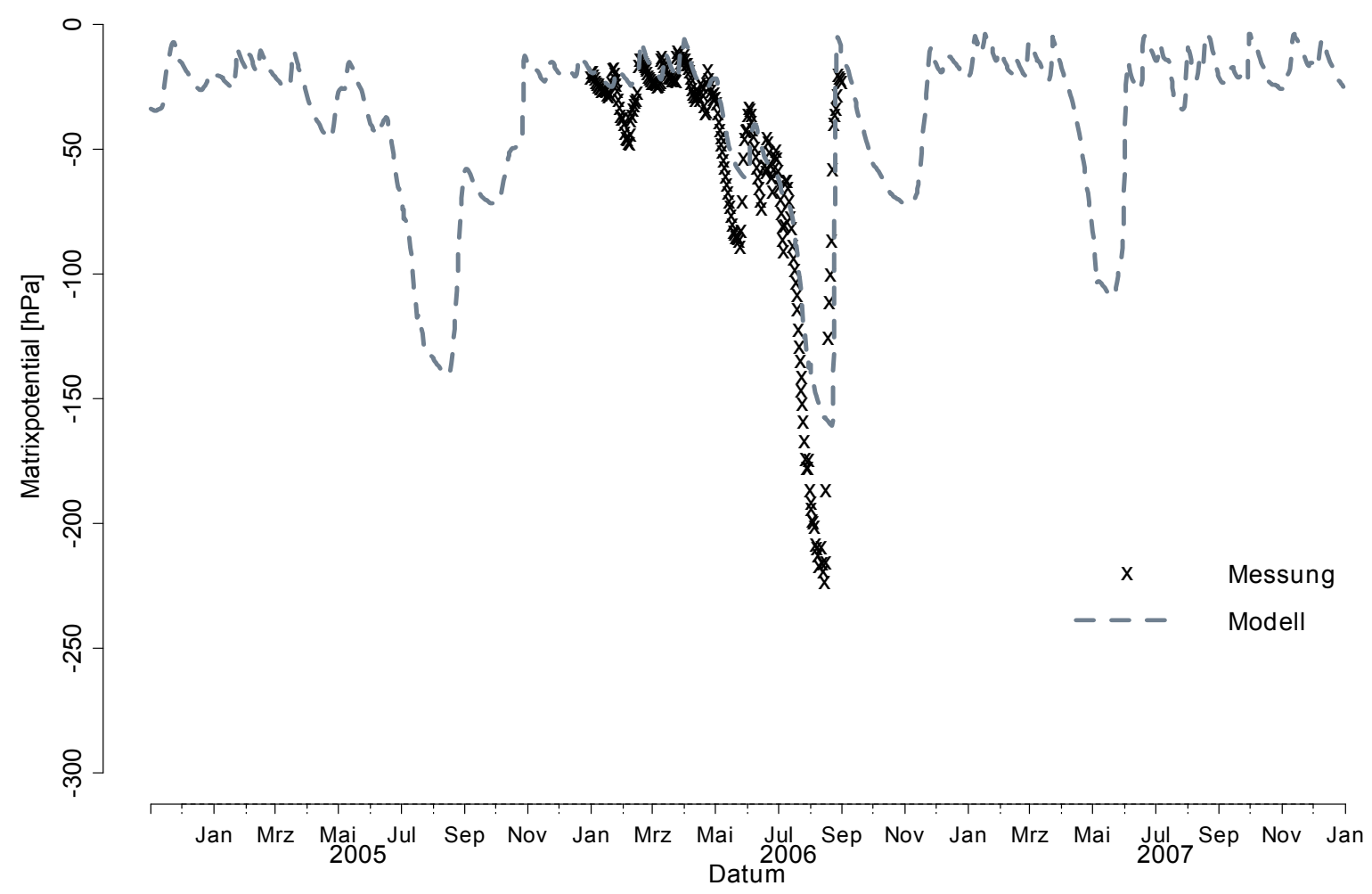

Abbildung 4-6: Bodenmatrixpotentiale in $60 \mathrm{~cm}$ Tiefe im Altbestand der Versuchsfläche Otterbach. Dargestellt sind die Modellergebnisse für den gesamten Untersuchungszeitraum und die Messwerte für den Kalibrierungszeitraum 1.1.2006-31.8.2006. 
Für die $20 \mathrm{~cm}$ Schicht im Altbestand zeigen die Gütemaßindices normierte Quadratsummenabweichung (-0.74), Modell-Effizienz-Index (0.70) und Mittelwertabweichung (130) ein innerhalb dieser Studie vergleichsweise schlechtes Abschneiden (Tabelle 4-5). Eine Verbesserung wird für die Schicht in $60 \mathrm{~cm}$ erreicht. Das Modell bildet unter dem Altbestand die Spitzen in Aufsättigungsphasen mit der Tiefe besser $a b$, wie aus den Abbildungen 4-5 und 4-6 ersichtlich ist, während die Austrocknungsphasen unabhängig von ihrer Stärke mit ungenügender Dynamik wiedergegeben werden. Die größere Dynamik in $20 \mathrm{~cm}$ Tiefe bewirkt eine steigende Anzahl geringer Abweichungen, was die eingangs erwähnte Verschlechterung der Indices bewirkt.

Für den Nordwestrand wurden zwei Simulationsläufe mit unterschiedlichen atmosphärischen Randbedingungen durchgeführt, wovon der erste den Strahlungsinput enthielt wie er für den Altbestand gemessen wurde (I) und der zweite einen erhöhten Strahlungsinput berücksichtigte (II), der die Exponiertheit des randlichen Bestandes einbezog.

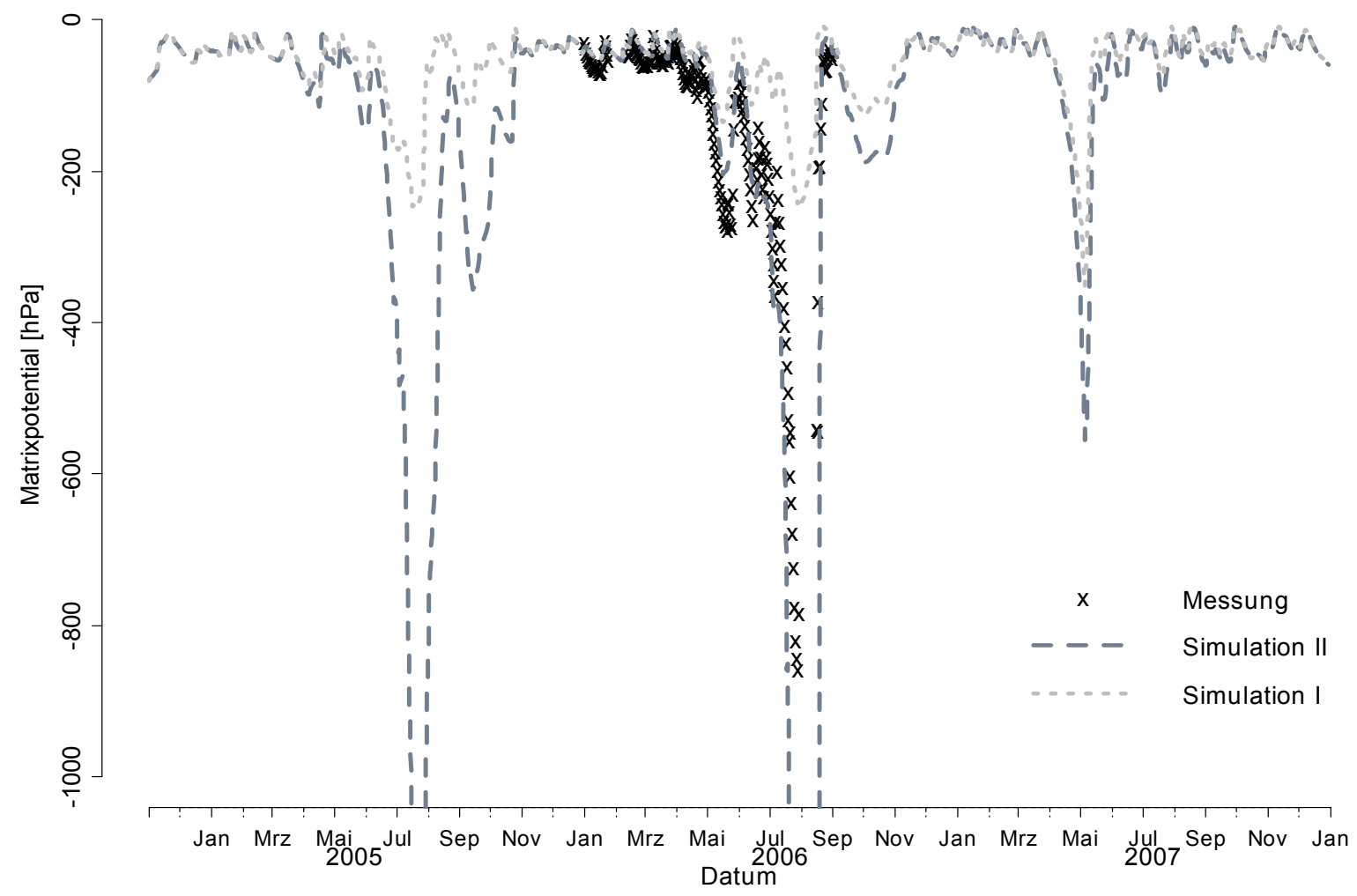

Abbildung 4-7: Bodenmatrixpotentiale in $20 \mathrm{~cm}$ Tiefe am Bestandesrand. Dargestellt sind die Ergebnisse der Simulationen I und II sowie der Messungen bis $800 \mathrm{hPa}$ (Messbereich der Tensiometer) für den Kalibrierungszeitraum 1.1.2006-31.8.2006 am Nordwestrand (B). Für Simulation I wurden die Strahlungsverhältnisse de Bestandesinneren herangezogen, während für Simulation II ein höherer Strahlungsinput implementiert wurde, der den lateralen Effekten Rechnung trägt. 


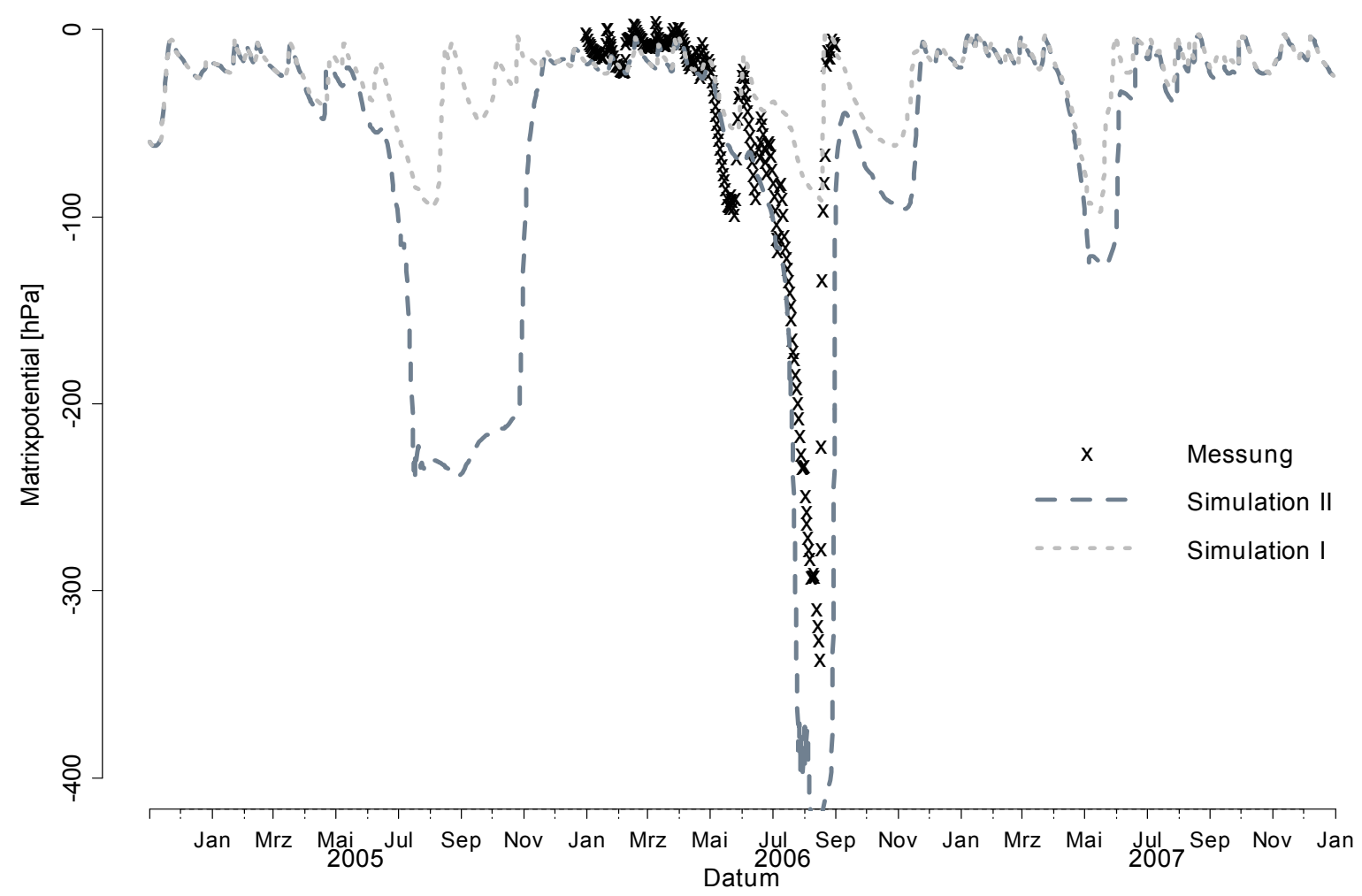

Abbildung 4-8: Bodenmatrixpotentiale in $60 \mathrm{~cm}$ Tiefe am Bestandesrand. Dargestellt sind die Ergebnisse der Simulationen I und II sowie der Messungen für den Kalibrierungszeitraum 1.1.2006-31.8.2006 am Nordwestrand (B). Für Simulation I wurden die Strahlungsverhältnisse de Bestandesinneren herangezogen, während für Simulation II ein höherer Strahlungsinput implementiert wurde, der den lateralen Effekten Rechnung trägt.

Eine Betrachtung der Dynamik in $20 \mathrm{~cm}$ Tiefe anhand von Abbildung 4-7 zeigt bei Simulation I eine ungenügende Wiedergabe der Austrocknungsphasen während der Vegetationsperioide. Dies verbessert sich stark nach der Modifizierung des Strahlungsaufkommens (Simulation II).

Jedoch deuten die normalisierten Quadratwurzelabweichungen für Simulation II eine Verschlechterung der Modellabbildung für die beiden Schichten in 20 und $60 \mathrm{~cm}$ Tiefe an (Tabelle 4-5). Die Modell-Effizienz-Inidices lagen nach Erhöhung des Strahlungsaufkommens im Mittelfeld (0.61 und 0.69), aber deutlich über denjenigen einer Modellierung ohne Strahlungsmodifikation (0.20 und 0.50). Auf Grund der hohen Dynamik an diesem Standort, treten neben wenigen stärkeren, zahlreiche im Betrag kleine Abweichungen auf, die zu einer Verschlechterung der Indizes führen. Weiterhin wird eine Verringerung der Abweichungen des mittleren modellierten Matrixpotentials für beide Tiefen durch die Berücksichtigung unterschiedlichen Strahlungsaufkommens erreicht (142 und $43 \mathrm{hPa}$ Abweichung versus 21 und $4 \mathrm{hPa}$ ).

Auch in $60 \mathrm{~cm}$ führte die Berücksichtigung eines erhöhten Strahlungsaufkommens am Nordwestrand (Station B in Abb. 4-1) zur Verbesserung der Abbildungsdynamik, wie Abbildung 4-8 zeigt. Im Gegensatz zum Altbestand wurde die sommerliche 
Austrocknung am Bestandesrand über ihren vollen Umfang hinaus abgebildet. Die Gütemaßindices (Tabelle 4-5) konnten durch Simulation II am Nordwestrand ebenfalls verbessert werden.

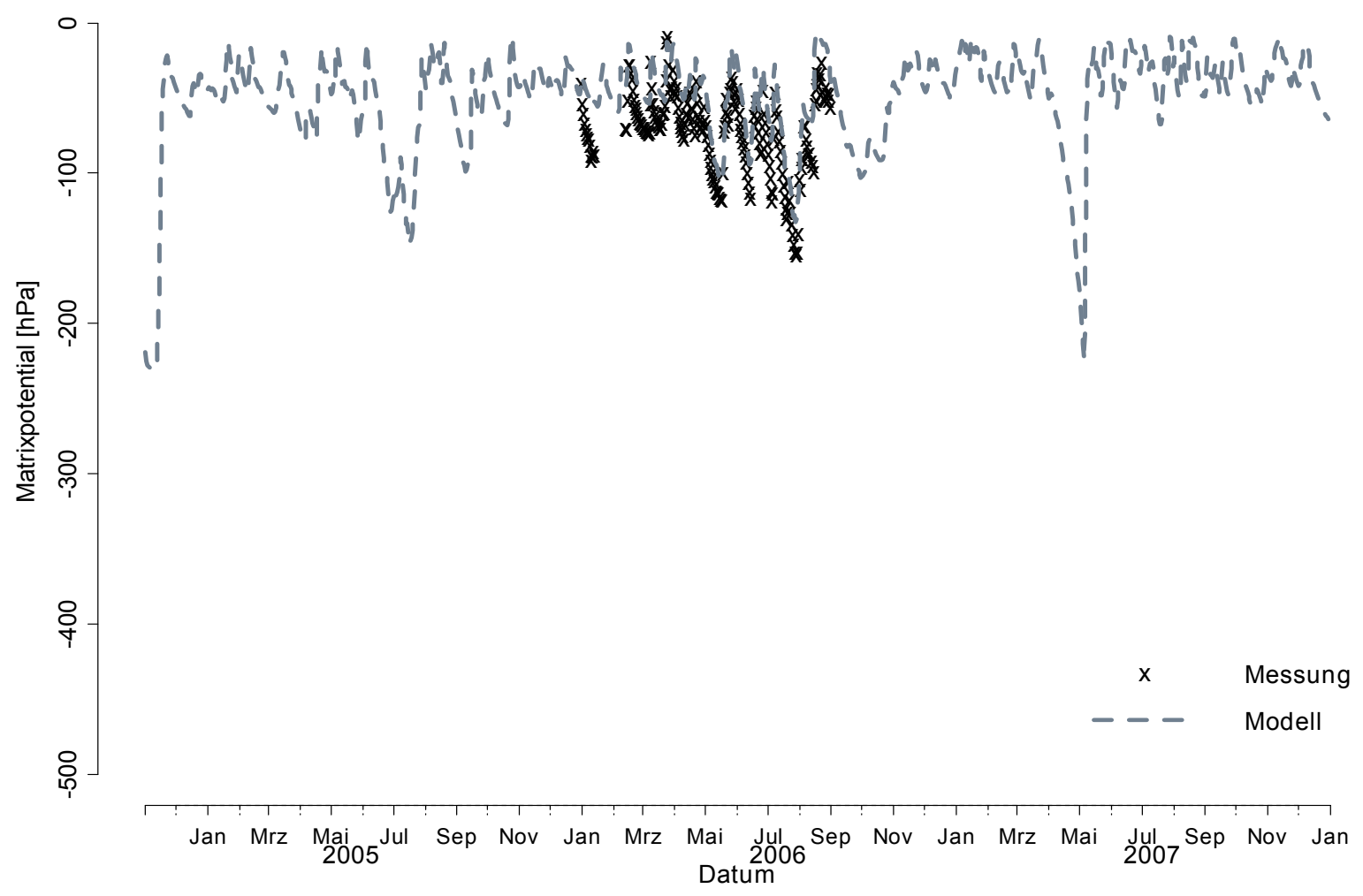

Abbildung 4-9: Bodenmatrixpotentiale in $20 \mathrm{~cm}$ Tiefe im Kahlschlagzentrum (C). Dargestellt sind die Modellergebnisse und die Messwerte für den Kalibrierungszeitraum 1.1.2006-31.8.2006.

Die Verbesserung fast aller Indizes in beiden Tiefen für die Simulation, die einen stärkeren Strahlungseinfall berücksichtigt, unterstreicht die Bedeutung des Strahlungshaushaltes an solchen Rändern und wird im Folgenden als das gültige Modell für diesen Standort betrachtet. Ferner zeigen diese Ergebnisse, dass die Erhöhung des Trockenstresses am Nordwestrand nicht nur auf einen geringer mächtigen Wurzelraum an diesem Standort zurückzuführen ist, da Matrixpotentiale von weniger als $-600 \mathrm{hPa}$ in $20 \mathrm{~cm}$ Tiefe erst unter Berücksichtigung des Strahlungseffektes erreicht werden.

Ganz im Gegensatz zu den Standorten unter Fichtenbestand wird im Modell für das Zentrum des Kahlschlags (Station $C$ in Abb. 4-1) die Dynamik der Austrocknungsphasen überschätzt, wie Abbildung 4-9 zeigt. Trotzdem wurden hier für die Schicht in $20 \mathrm{~cm}$ Tiefe die besten Gütemaßindices innerhalb dieser Studie erzielt $(-0.30$ und 0.85 , siehe Tab. 4-5).

Kongruent zu den vorangegangenen Beispielen wird die geringere Austrocknungsdynamik in $60 \mathrm{~cm}$ Tiefe besser abgebildet (siehe Abb. 4-10), obwohl IA und NRMSE eine Verschlechterung des Modells anzeigen (Tab. 4-5). Dies liegt jedoch an teilweise 
positiven Matrixpotentialen in den tieferen Lagen auf dem Kahlschlag. Diese können mit einem Modell basierend auf der Richardsgleichung nicht nachgezeichnet werden und wirken sich negativ auf die Maßzahlen aus. Eine besonders auffällige Abweichung zwischen Modell und Messungen ist im August $2006 \mathrm{zu}$ beobachten. Während die Messungen hier eine rapide, zweigeteilte Aufsättigungsphase zeigen, verläuft diese im Modell vergleichsweise träge (Abb. 4-10). Als mögliche Ursachen hierfür werden Fliessbedingungen angenommen, die mit einem Modellansatz nach Richards ebenfalls nicht hinreichend aufgelöst werden können. Auf der Freifläche sind entlang ehemaliger Wurzelkanäle Wasserführungen entstanden, die unter bestimmten Voraussetzungen als Bypass fungieren und die Wassergehalte in tieferen Schichten höher halten als erwartet, wie in Kapitel 5 (Fröhlich et al., 2009b) dargelegt ist. Eine bedeutende Rolle für diese Prozesse spielt die Hydrophobizität der Humusauflagen in Abhängigkeit vom Wassergehalt. Letztendlich werden die Matrixpotentiale durch diesen Effekt für nur relativ kurze Zeiträume unterschätzt, was aber zu den genannten Verschlechterungen der Indices IA und NRMSE in den tieferen Schichten führt.

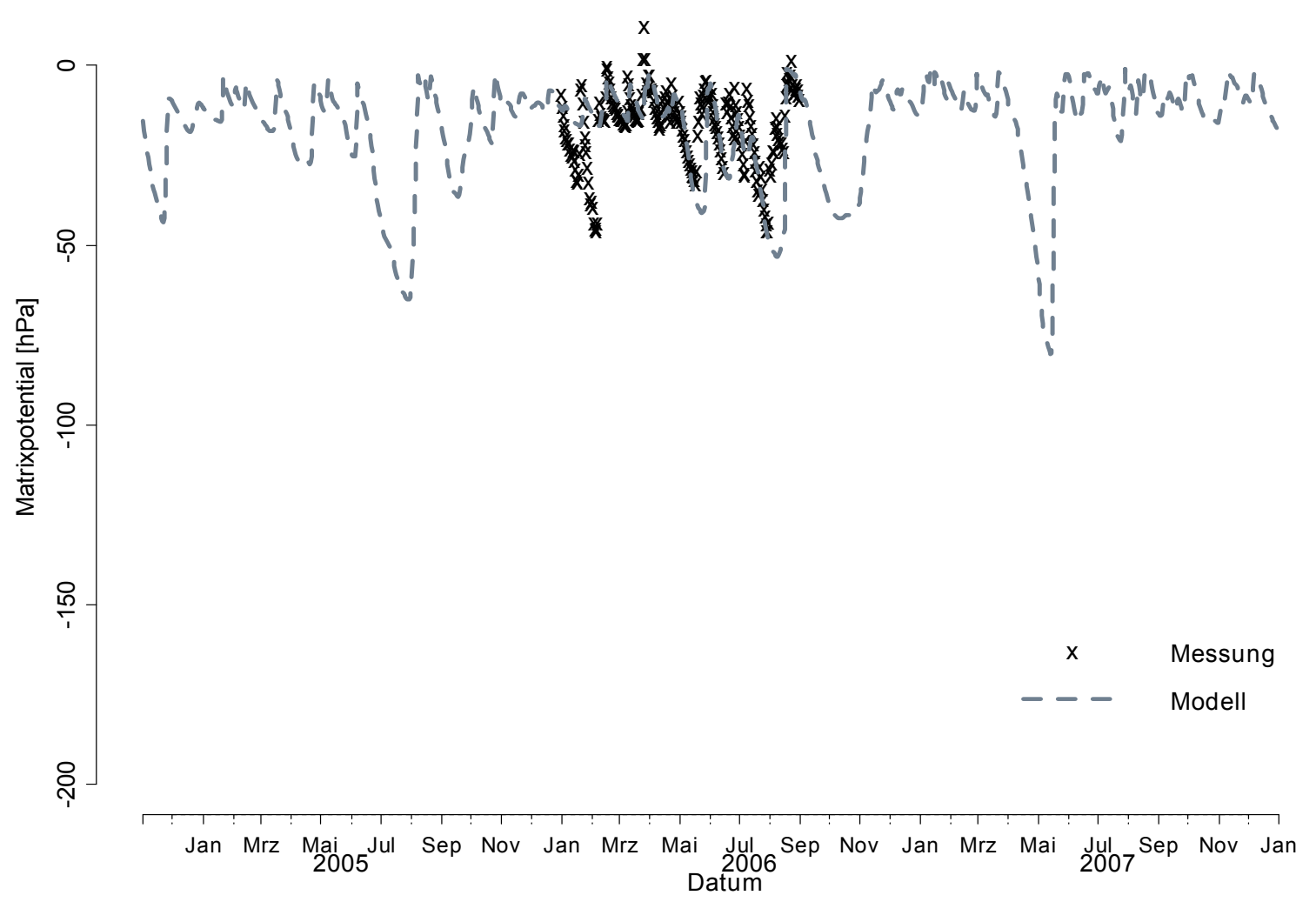

Abbildung 4-10: Bodenmatrixpotentiale in $60 \mathrm{~cm}$ Tiefe im Kahlschlagzentrum (C). Dargestellt sind die Modellergebnisse und die Messwerte für den Kalibrierungszeitraum 1.1.2006-31.8.2006.

Auch für den Südwestrand der Freifläche (Station $D$ in Abb. 4-1) wurden zwei Simulationsläufe durchgeführt, einer mit den Strahlungsverhältnissen, wie sie im Zentrum des Kahlschlags herrschen und einer der den Strahlungsabfall an länger beschatteten Rändern berücksichtig. Eine Überschätzung der Spitzen in den 
Austrocknungsphasen wurde für beide Tiefen $(20$ und $60 \mathrm{~cm}$ ) durch die Änderung dieser Randbedingung deutlich verringert, wie aus den Abbildungen 4-11 und 4-12 ersichtlich ist. Dies verdeutlicht die Rolle des Strahlungshaushaltes auch bei hohen Sättigungsgraden. Die Kennzahlen für die Modellgüte wurden ebenfalls verbessert (Tab. 4-5). Die Abweichungen zwischen Mess- und Modellwerten weisen an diesem Standort auf das Vorhandensein eines nicht-Darcy-Flusses hin, wie dies bereits für das Zentrum des Kahlschlags diskutiert wurde. Das schlechtere Abschneiden der Gütemaßindices der $60 \mathrm{~cm}$ Schicht gegenüber dem Kahlschlag Zentrum (Tab. 4-5) ist in den länger anhaltenden Sättigungsphasen und einer höheren Ausfallquote der Messinstrumente an diesem Standort (D) begründet.

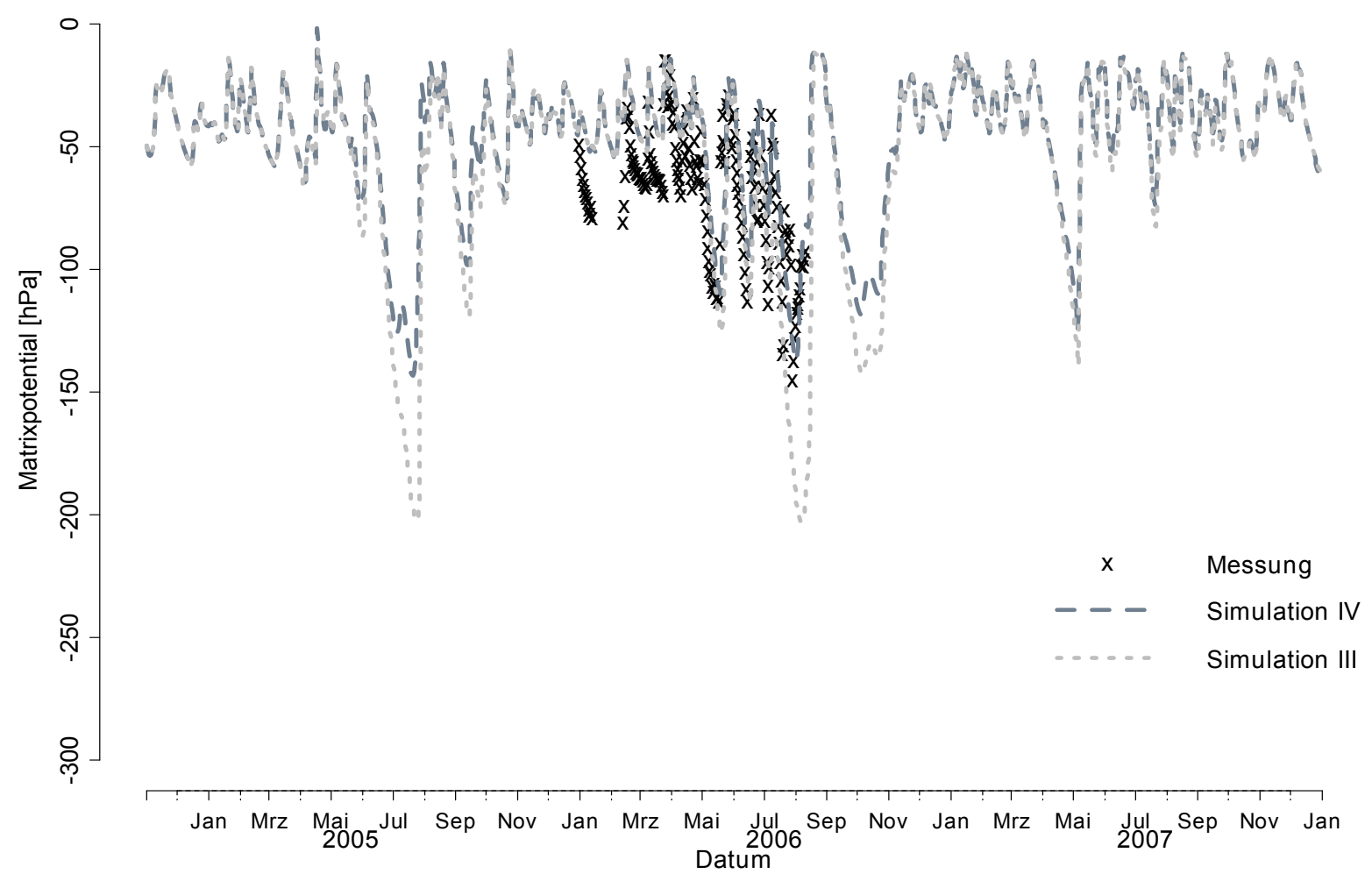

\begin{abstract}
Abbildung 4-11: Bodenmatrixpotentiale in $20 \mathrm{~cm}$ Tiefe am Südwestrand des Kahschlags (D). Dargestellt sind die Ergebnisse der Simulationen III und IV sowie die Messwerte für den Kalibrierungszeitraum 1.1.2006-31.8.2006. Simulation III wurde mit Strahlungswerten des Kahlschlagzentrums durchgeführt, während ein reduziertet Strahlungsinput der Simulation IV den lateralen Einfluss des umgebenden Bestands berücksichtig.
\end{abstract}

Die peripheren Lagen des untersuchten Kleinkahlschlags weisen also stark unterschiedliche Hydroregime auf, sowohl im Vergleich zueinander (Wasserüberschuss und Wassermangel) als auch im Vergleich zum Kahlschlagzentrum. Bei waldbaulichen Maßnahmen sollte dies durch eine geeignete Baumartenwahl berücksichtigt werden. Zum anderen kann durch die Größe und Form einer zu schaffenden Kahlfläche auf die beeinflussten Randbereiche eingewirkt werden. 


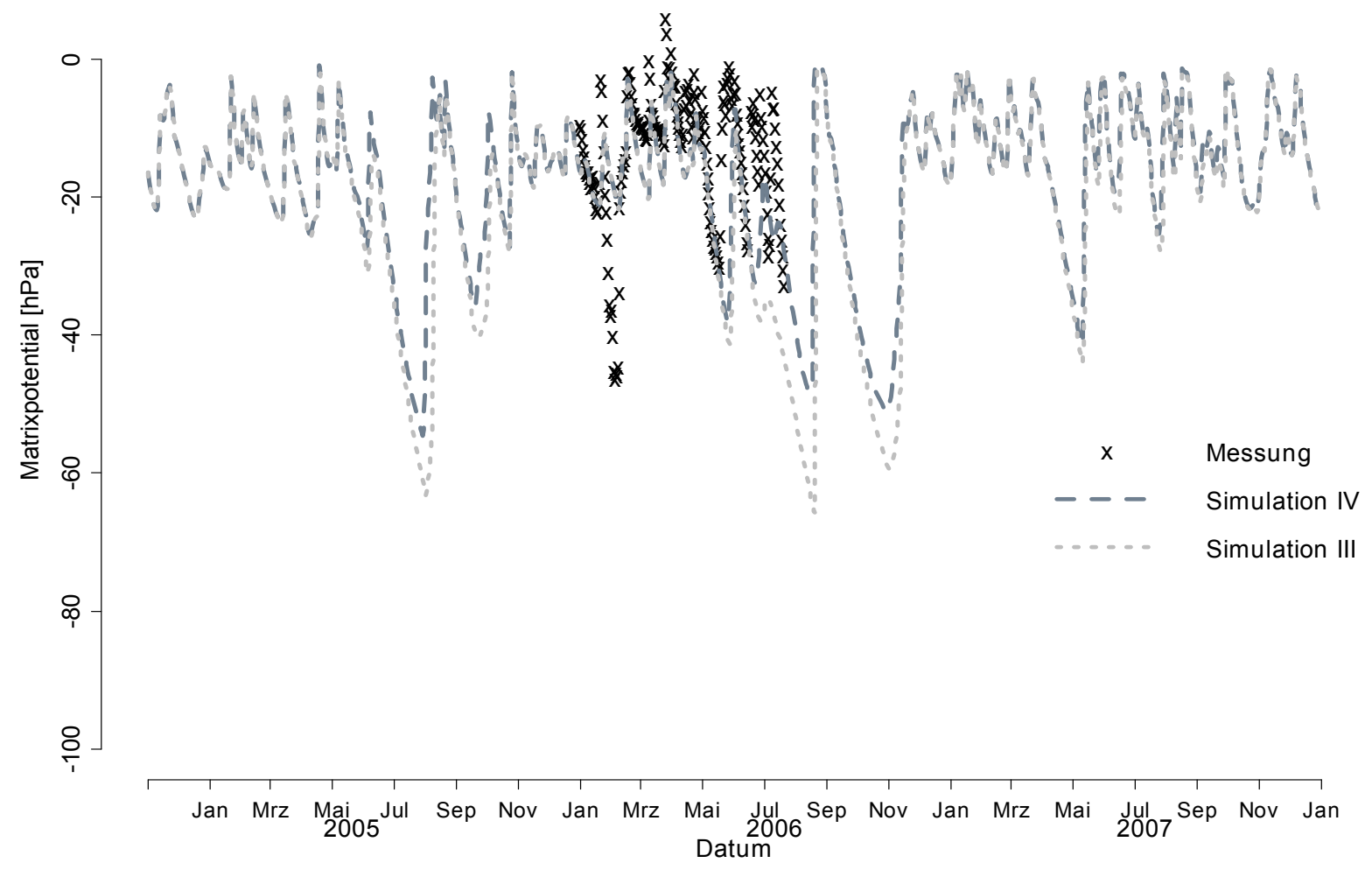

Abbildung 4-12: Bodenmatrixpotentiale in $60 \mathrm{~cm}$ Tiefe am Südwestrand des Kahlschlags (D). Dargestellt sind die Ergebnisse der Simulationen III und IV sowie die Messwerte für den Kalibrierungszeitraum 1.1.2006-31.8.2006. Simulation III wurde mit Strahlungswerten des Kahlschlagzentrums durchgeführt, während ein reduziertet Strahlungsinput der Simulation IV den lateralen Einfluss des umgebenden Bestands berücksichtig.

Die Ergebnisse der Wasserhaushaltsmodellierung unter EXPERT-N sind zufrieden stellend sowohl für den Altbestand als auch für die unter forstwirtschaftlichem Eingriff stehenden Flächen. Schwierigkeiten treten in den tieferen Abschnitten auf der Freifläche und bei der Abschätzung des Interzeptionsverlustes auf. Eine Berücksichtigung der unterschiedlichen meteorologischen Randbedingungen führte zu deutlichen Verbesserungen der Modellergebnisse am Nordwestrand und zumindest für die Tiefe in $20 \mathrm{~cm}$ am Südwestrand Deshalb wurden die Größen der Wasserhaushaltsbilanz für die Modelle, die die Randeffekte berücksichtigen, in Tabelle 4-6 angegeben. Im Vergleich sind dazu in Tabelle 4-7 die Spannen der Wasserhaushaltsgrößen von 59 Flächen West- und Mitteleuropäischer Waldstandorte (de Vries et al., 2001) sowie die Simulationsergebnisse für Fichtenaltbestände im Solling (Eckersten et al., 1995; Salihi, 1984) angegeben. 
Tabelle 4-6: Jährliche Wasserbilanzen für die ersten drei Jahre nach Durchführung des Kahlschlags (2005-2007)

\begin{tabular}{|c|c|c|c|c|c|c|c|c|c|}
\hline Jahr & $\begin{array}{l}\text { Nieder-. } \\
\text { schlag }\end{array}$ & $\begin{array}{l}\text { Evapo- } \\
\text { transp. pot. }\end{array}$ & \multicolumn{2}{|c|}{ Evaporation } & \multicolumn{2}{|c|}{$\begin{array}{l}\text { Transp. } \\
\text { pot. akt. }\end{array}$} & $\begin{array}{l}\text { Inter- } \\
\text { zeption }\end{array}$ & Drainage & $\begin{array}{l}\text { Wasser- } \\
\text { speicher }\end{array}$ \\
\hline \multicolumn{10}{|c|}{ Bestand } \\
\hline 2005 & 851 & 606 & 24 & 9 & 372 & 371 & 208 & 276 & +2 \\
\hline 2006 & 896 & 611 & 24 & 11 & 370 & 370 & 214 & 332 & -1 \\
\hline 2007 & 1336 & 577 & 23 & 12 & 301 & 301 & 251 & 790 & -17 \\
\hline \multicolumn{10}{|c|}{ Nordwestrand } \\
\hline 2005 & 851 & 740 & 164 & 55 & 376 & 376 & 200 & 231 & +1 \\
\hline 2006 & 896 & 762 & 169 & 72 & 369 & 359 & 222 & 267 & $+/-0$ \\
\hline 2007 & 1336 & 730 & 161 & 69 & 311 & 311 & 262 & 711 & -16 \\
\hline \multicolumn{10}{|c|}{ Kahlschlag-Zentrum } \\
\hline 2005 & 851 & 606 & 236 & 22 & 241 & 241 & 125 & 469 & +1 \\
\hline 2006 & 896 & 611 & 238 & 27 & 240 & 240 & 133 & 516 & $+/-0$ \\
\hline 2007 & 1336 & 577 & 225 & 40 & 193 & 193 & 158 & 962 & -16 \\
\hline \multicolumn{10}{|c|}{ Südwestrand } \\
\hline 2005 & 851 & 507 & 201 & 53 & 189 & 179 & 110 & 511 & $+/-0$ \\
\hline 2006 & 896 & 512 & 160 & 53 & 220 & 206 & 135 & 514 & +1 \\
\hline 2007 & 1336 & 481 & 179 & 77 & 144 & 139 & 157 & 977 & -19 \\
\hline
\end{tabular}

Der Mittelwert der Niederschläge aus den Jahren 2005-2007 liegt mit 1028 mm im Bereich der Werte, die von Eckersten und Salihi angegeben werden. Für den Altbestand liegen die annuellen Werte der Modellierung der Wasserhaushaltskomponenten im mittleren Bereich des Spektrums für europäische Waldstandorte (Tab. 4-7). In den beiden niederschlagsarmen Jahren 2005 und 2006 werden die Werte für den Kronendurchlass und um 68-143 mm unterschritten, während die Werte der Transpiration bzw. potentieller Evapotranspiration um ca. 130 bzw. 290 mm über denjenigen früherer Modellierungen liegen. Diese Werte verdeutlichen die rezenten Spannweiten und die Schwankungsbreite der Bilanzgrößen in einem Bergland mit Fichtenanbau. Die Tiefensickerung lag in den beiden niederschlagsarmen Jahren konsequenter Weise 151 bzw. 95 mm unter denjenigen der zitierten Studien, der Mittelwert aus allen drei Jahren hingegen lag für den Altbestand mit $466 \mathrm{~mm}$ über den Angaben von Eckersten (1995) und Salihi (1984).

Tabelle 4-7: Größen der Wasserhaushaltskomponenten im europäischen Vergleich (de Vries et al., 2006) und frühere Modellergebnisse für Studien unter Fichtenaltbestand im Hochsolling (Eckersten et al., 1995; Salihi, 1984)

\begin{tabular}{|c|c|c|c|c|c|c|c|}
\hline Quelle & $\begin{array}{l}\text { Nieder- } \\
\text { schlag }\end{array}$ & $\begin{array}{l}\text { Kronen- } \\
\text { durchlass }\end{array}$ & $\begin{array}{l}\text { Inter- } \\
\text { zeption }\end{array}$ & $\begin{array}{l}\text { Evaporation } \\
\mathrm{mm} / \mathrm{a}\end{array}$ & $\begin{array}{l}\text { Trans- } \\
\text { piration }\end{array}$ & $\begin{array}{l}\text { Evapotrans } \\
\text { transpiration }\end{array}$ & $\begin{array}{l}\text { Tiefen- } \\
\text { sickerung } \\
--\end{array}$ \\
\hline de Vries & $800-2000$ & $500-1500$ & & $10-180$ & $200-500$ & $400-1100$ & $0-700$ \\
\hline Eckersten & 1115 & 784 & 331 & 64 & 243 & 307 & 427 \\
\hline Salihi & 1025 & 747 & 278 & & & 328 & 419 \\
\hline
\end{tabular}


Am Nordwestrand stieg durch die hohe Energiezufuhr die potentielle Evapotranspiration gegenüber dem Altbestand stark an (Tab 4-6), die Auswirkung auf die aktuelle Transpirationsleistung betrug nur wenige $\mathrm{mm}$, da die Auflichtung durch den Übergang Bestand-Kahlschlag berücksichtigt wurde. Wasserstress - indiziert durch die Differenz aus potentieller und aktueller Transpiration -, wie aus den Messungen der Matrixpotentiale zu folgern wäre, konnte in keinem der drei Beobachtungsjahre durch das Modell für den Altbestand (A) gezeigt werden. Erst die Trockenheit im Sommer 2006 führte am Bestandesrand (B) im Modell zu einer eingeschränkten Transpiration. Die mittlere Drainage verringerte sich um $63 \mathrm{~mm}$ gegenüber dem Altbestand (A). Auf der Freifläche traten am Südwestrand (D) ebenfalls Differenzen zwischen potentieller und aktueller Transpiration auf. Diese lagen im mittel bei $10 \mathrm{~mm}$. Dies steht im Einklang mit den Beobachtungen aus den Messungen des Matrixpotentials. Änderungen in der Drainage, die am Südwestrand (D) bis zu $42 \mathrm{~mm}$ über derjenigen des Kahlschlagzentrums (C) lag, sind im Wesentlichen auf den Einfluss der Strahlung zurückzuführen und verdeutlicht noch einmal deren Bedeutung für die peripheren Standorte.

Der Vergleich mit den zitierten Studien zeigt die Plausibilität des Modells. Ferner wurde die Möglichkeit demonstriert mittels Modellierung die Komponenten des Wasserhaushalts auf Kleinkahlschlagflächen und in ihrer Umgebung zu beschreiben und ein differenziertes Bild zu gewinnen. Dies ist unter dem Aspekt der Wiederaufforstung (vgl. York et al., 2003) insbesondere aber im Hinblick auf die Stoffumsätze und -verlagerungen und daraus resultierende Bewertung von Kleinkahlschlägen nötig. Da die Randbereiche, in denen erhebliche Abweichungen von den Zentren auftreten können, zeitweise eine größere Fläche als das Kahlschlagzentrum einnehmen (siehe Kap. 3, Fröhlich et al., 2009b), müssen diese Areale in Zukunft besser beachtet werden.

\section{Danksagung}

Die Autoren bedanken sich bei der ,Deutschen Forschungsgemeinschaft' für die finanzielle Unterstützung des Projektes BE 713/27-1. Auch möchten sich die Autoren bei Herrn Mühlhan für die wertvolle und engagierte Unterstützung bei Inbetriebnahme und Wartung der Messanlage bedanken. 


\subsection{Literatur}

Aboal, J.R., M.S. Jiménez, D. Morales and P. Gil, 2000. Effects of thinning on throughfall in Canary Islands pine forest - The role of fog. J. of Hydrology 238, 218-230

Adams, P.W., A.L. Flint and R.L. Fredriksen, 1991. Long-term patterns in soil moisture and revegetation after a clearcut of a Douglas-fir forest in Oregon. Forest Ecology and Management 41, 249-263.

Adams, R.S., T.A. Black and R.L. Flemming, 1991. Evapotranspiration and surface conductance in a high elevation, grass-covered forest clear-cut. Agricultural and Forest Meteorology 56 (3-4), 173-193.

Armbruster, M., J. Seegert and K.-H. Feger, 2004. Effects of changes in tree species composition on water flow dynamics -Model applications and their limitations. Plant and Soil 264, 13-24.

Bartsch, N., J. Bauhus and T. Vor, 2002. Effects of group selection and liming on nutrient cycling in an European beech forest on an acidic soil. In: Dohrenbusch, A. and N. Bartsch (eds.): Forest developement - Succession, environmental stress and forest management. Springer, Berlin, 109142

Bauhus, J., 1994. Stoffumsätze in Lochhieben. Ber. Forschungszentrum Waldökosysteme, Göttingen, Reihe A, Bd. 113, 1-181

Bäumler, R., and W. Zech, 1997. Atmospheric deposition and impact of forest thinning on the throughfall on mountain forest ecosystems in the Bavarian alps. Forest Ecology and Management 95, 243-251

Benecke, P., und R.R. van der Ploeg, 1978. Wald und Wasser. 1. Komponenten des Wasserhaushaltes von Waldökosystemen. 1978. Forstarchiv 49, 1-7.

Benecke, P., 1984. Der Wasserumsatz eines Buchen- und eines Fichtenwaldökosystems im Hochsolling. Schriften aus der Forstlichen Fakultät der Universität Göttingen und der Niedersächsischen Forstlichen Versuchsanstalt, 77.

Breuer, L., H. Eckard and H.-G Frede. 2003. Plant parameter values for models in temperate climate. Ecological Modelling, 169, 237-293.

Bowen, H.D., 1976. Correlations of penetrometer cone index with root impedance. American Society of Agricultural Engineers, 76, 1516-152.

Camargo, J.L.C., and V. Kapos, 1995. Complex Edge effects on soil-moisture and microclimate in central Amazonian forest. 1995. Journal of Tropical Ecology, 11, 205-221.

Carvalho, K.S., and H,L. Vasconcelos, 1999. Forest fragmentation in central Amazonia and its effects on litter-dwelling ants. Biological Conservation, 91 (2-3), 151-157.

Cienciala, E., P.-E. Mellander, J. Kučera J., M. Opluštilová, M. Ottosson-Löfvenius and K. Bishop, 2002. The effect of a north-facing forest edge on tree water use in a boreal Scots pine stand. Canadian Journal for Forest Research. 32, 693-702.

De Keersmaeker, L., J. Neirynck, D. Maddelein, A. de Schrijver and N. Lust, 2000. Soil water chemistry and revegation of a limed clearcut in a nitrogen saturated forest. Water Air Soil Poll. 122, 49-61 
de Vries, W., G.J. Reinds, C. van der Salm, G.P.J. Draaijers, A. Bleeker, J.W. Erisman, J. Auée, P. Gundersen, H.L. Kristensen, H. van Dobben, D. de Zwart, J. Derome, J.C.H. Voogd, E.M. Vel, 2001. Intensive Monitoring of Forest Ecosystems in Europe - Technical Report 2001. Ec-Un/ECE, Brussels, Geneva.

Didham, R.K., J.H. Lawton, P.M. Hammond and P. Eggleton, 1998a. Trophic structure stability and extinction dynamics of beetles (Coleoptera) in tropical forest fragments. Philosophical Transactions of the Royal Society of London Series B-Biological Sciences, 353 (1367), 437-451.

Didham, R.K., J.H. Lawton, P. Eggleton and N.E. Stork, 1998b. Beetle species responses to tropical forest fragmentation. Ecological Monographs, 68 (3), 295-323.

Didham, R.K., 1998c. Altered leaf litter decomposition rates in tropical forest fragments. Oecologia, 116 (3), 397-406.

Didham, R.K., and J.H. Lawton, 1999. Edge structure determines the magnitude of changes in microclimate and vegetation structure in tropical forest fragments. Biotropica, 31(7), 17-30.

Dube, S., A.P. Plamondond, and R.L. Rothwell, 1995. Watering up after clear-cutting on forested wetlands of the ST-Lawrence lowland. Water Resources Research, 31 (7), 1471-1750.

Eckersten, H., A. Gärdenäs and P.-E- Jansson, 1995. Modeling seasonal nitrogen, carbon, water and heat dynamics of the Solling spruce stand. Ecological Modeling, 83, 119-129.

Feddes, R.A., E. Bresler and S.P. Neuman, 1974. Field-Test of a modified numerical-model for water uptake by root systems. Water Resources Research, 10, 1199-1206.

Fleming, R.L., T.A. Black, R.S. Adams and R.J Stathers, 1997. Silvicultural treatments, microclimatic conditions and seedling response in Southern Interior clearcuts. Canadian Journal of Soil Science, $78,115-126$.

Forstliche Kartieranleitung. 2003. IHW-Verlag und Verlagsbuchhandlung. Eching.

Fröhlich, D., U. Klinck and F. Beese, 2009a. Temporal and spatial variations of two-sided edge effects on small clear cuts. In: Raumzeitliche Dynamik der Parameter des Energie-, Wasser- und Spurengashaushalts nach Kleinkahlschlag. Dissertation.

Fröhlich, D., J. Prenzel and F. Beese, 2009b. Management induced heterogeneity of soil water redistribution in forested areas. In: Raumzeitliche Dynamik der Parameter des Energie-, Wasser- und Spurengashaushalts nach Kleinkahlschlag. Dissertation.

Gash, J.H.C., and A.J. Morton, 1978. An application of the Rutter model to the estimation of the interception of the Thetford Forest. 1978. Journal of Hydrology, 38, 49-58.

Grunwald, S., B. Lowery, D.J. Rooney and K. McSweeney, 2001. Profile cone penetrometer data used to distinguish between soil materials. Soil and Tillage Research, 62, 27-40.

Hörmann, G., J. Scherzer, F. Suckow, J. Müller, M. Wegehenkel, M. Lukes, K. Hammel, A. Kniess and H. Meesenburg, 2003. Wasserhaushalt von Waldökosystemen: Methodenleitfaden zur Bestimmung der Wasserhaushaltskomponenten auf Level-II-Flächen. 2003 - BMVEL, Referat 533, Bonn: 92p. 
Hüser, R., H.W. Führer und K.E. Rehfuess, 1996. Wasserchemische Auswirkungen von Hiebseingriffen im Krofdorfer Buchenforst. Forst u. Holz 51, 666-672

Kapos, V., G. Ganade, E. Matsui and R.L. Victoria, 1993. Partial-derivative-C-13 as an indicator of edge effects in tropical Rain-Forest reserves. Journal of Ecology, 81 (3), 425-432.

Katzensteiner, K., 2003. Effects of harvesting on nutrient leaching in a Norway spruce Picea abies Karst.) ecosystem on a Lithic Leptosol in the Northern Limestone Alps. Plant and Soil (250), 59-73.

Klaasen, W., H.J.M. Lankreijer, A.W.L. Veen, 1996. Rainfall interception near a forest edge. Journal of Hydrology 185, 349-361.

Likens, G.E., F.H. Bormann, N.M. Johnson, D.W. Fischer and R.S. Pierce, 1970. Effects of forest cutting and herbicide treatment on nutrient budgets in the Hubbard Brook watershed-ecosystem. Ecological Mongraphs 40, 1, 23-47

Lovejoy, T. E., R. 0. Bierregaard, Jr.,. A. B. Rylands, J. R. Malcolm, C. E. Quintela, L. H. Harper. K. S. Brown. Jr., A. H. Powell, G. V. N. Powell, H. 0 . R. Schubart and Hays, M.B., 1986. Edge and other effects of isolation on Amazon forest fragments. Pages 257-285 in M. E. Soule, Editor. Conservation biology: the science of scarcity and diversity. Sinauer Associates, Sunderland, Massachusetts, USA.

Lorz, C., M. Volk and G. Schmidt, 2007. Considering spatial distribution and functionality of forests in a modeling framework for river basin management. Forest Ecology and Management 248, 17-25.

Mäkitalo, K., and J. Hyvönen, 2004. Late soil water content on clear cut reforestation areas two decades after site preparation in Finnish Lapland. Forest Ecology and Management 189, 57-75.

Marthews, T.R, D.F.R.P. Burslem, S.R. Panton, F. Ynyuez and C. E. Mullins, 2008. Soil drying in a tropical forest: Three distinct environments controlled by gap size. Ecological Modelling 216 (3-4), 369-384.

Moore, R.D., and S.M. Wondzell, 2005.Physical hydrology and the effects of forest harvesting in the Pacific Northwest: a review. Journal of the American Water Resources Association. Paper No. 04065.

Niedersächsisches Gesetz über den Wald und die Landschaftsordnung (NWaldLG). Vom 21. März 2002 (Nds. GVBI. S. 112), geändert durch Artikel 16 des Gesetzes vom 12. Dezember 2003, geändert durch Artikel 4 des Gesetzes vom 16.12.2004 (Nds. GVBI. S. 616).

Panferov, O., Knyazikhin, Y., Myneni, R.B., Szarzynski, J., Engwald, S., Schnitzler, K.G., Gravenhorst, G., 2001. The role of canopy structure in the spectral variation of transmission and absorption of solar radiation in vegetation canopies. IEEE Transactions on Geoscience and Remote Sensing, 39, 241-253.

Parfitt, R.L., G.J. Salt and L.F. Hilt, 2002. Clear-cutting reduces nitrate leaching in a pine plantation of high natural $\mathrm{N}$ status. Forest Ecology and Management 170, 43-53

Peschel, T., J. Mrzljak and Wiegleb G. (Hrsg.), 2002. Landschaft im Wandel - Ökologie im Wandel Changing Landscapes - Changing Ecology. Verlag Die Werkstatt, Göttingen.

Priesack, E., 2006. Expert-N Dokumentation der Modellbibliothek. Hieronymus-Verlag, München. 
R statistical Package: R Development Core Team, 2005

Radler, K., A. Oltchev, O. Panferov and G. Gravenhorst, 2008. Radiation and temperature responses to a small clear-cutting in a spruce forest. 2008. European Journal of Forest Research. Submitted.

Sachs, L., und J. Hedderich, 2006. Angewandte Statistik Methodensammlung mit R. Springer Verlag Berlin, heidelberg New York.

Salihi, O.O.A., 1984. Potenitelle Verdunstung eines Buchen- und eines Fichtenwaldes auf der Basis von Daten des Deutschen Wetterdienstes als Parameter der aktuellen Evapotranspiration. Dissertation.

Sinnett, D., G. Morgan, M. Williams, and T.R. Hutchings, 2008. Soil penetration resistance and tree root developement. Soil Use and Management, 24. (3), 273-280.

Teepe, R., H. Delling and F. Beese, 2003. Estimating water retention curves of forest soils from texture and bulk density. Journal of Plant Nutrition and Soil Science, 166, 111-119.

Trevor, L., 1998. The effect of deforestation on ground surface temperatures. Global and Planetary Change, 18, 1-13.

van Genuchten, M., 1980. A closed-form equation for predicting the hydraulic conductivity of unsaturated soils. Soil Science Society of Ammerica Journal, 44, 892-898.

von Wilpert, K., 1990. Die Jahrringstruktur von Fichten in Abhängigkeit vom Bodenwasserhaushalt auf Pseudogley und Parabraunerde. Freiburger Bodenkundliche Abhandlungen.

Wallach, D., and B. Goffinet, 1989. Mean Squared Error of prediction as a criterion for evaluation and comparing system models. Ecological Modelling, 44, 299-306.

Wegehenkel, M., 2005. Validation of a soil water balance model using soil water content and pressure head data. Hydrological Processes, 19, 1139-1164.

Wegehenkel, M., und H. Jocheim, 2003. Modellierung des Wasserhaushalts von Kiefernbeständen des Level-II-Programms mit unterschiedlich komplexen Simulationsmodellen. Forstwissenschaftliches Centralblatt, 122, 302-317.

Willmot, C.J., 1982. Some comments on the evaluation of model performance. Bulletin American Meteorological Society, 1309-1313.

York, R.A., J.J. Battles and R.C. Heald, 2003. Edge effects in mixed conifer group selection openings: tree height response to resource gradients. Forest Ecology and Management, 179, 107-121. 


\section{Management induced heterogeneity of soil water redistribution in forested areas}

\section{Daniel Fröhlich $^{1}$, Jürgen Prenzel ${ }^{1}$ and Friedrich Beese ${ }^{1}$}

1 Büsgen-Institute, Department for soil science of temperate and boreal ecosystems, University of Göttingen, Büsgenweg 2, 37077 Göttingen, Germany

Key words: clear cut, preferential flow, snow melt, summer storm, in situ water content measurement

Corresponding author: Daniel Fröhlich, e-mail: dfroehl@gwdg.de

\subsection{Summary}

The redistribution pattern of soil water under closed Norway spruce (Picea abies L.) canopy and an adjacent cleared site after a rapid snow melt and a storm event following a summer drought spell are presented. For a synoptic inspection with comparable hydraulic attributes, both sites were equipped in the same way for continuous monitoring of water content $\left(\mathrm{ECH}_{2} \mathrm{O}\right.$-probes, Decagon) and matric potentials (pressure transducer tensiometers). Precipitation was measured with a heated rain gauge in the middle of the cleared site. Before installing the $\mathrm{ECH}_{2} \mathrm{O}$ probes, their behaviour was tested in the lab and calibration functions were established, since the calibration line as suggested by Decagon (2006) did not fit our data very well.

Initial conditions before the snow melt were similar among the both sites, except the higher snowpack water equivalent on the surface of the cleared site. The increase of soil water content in the deeper soil layer under closed canopy was small. In contrast at the cleared site the soil water content increased distinct and immediately with the beginning of the snow melt in the subsoil. This occurred against an upward hydraulic gradient indicating non-Darcy flow.

After the summer drought the initial conditions of the soil profiles differed notably, showing lower soil matric potentials and water content under closed canopy. In the clear cut the water reached deeper soil layers more rapidly and the subsoil was partially filled up against upward hydraulic gradients indicating preferential pathways.

These differences in amount and dynamics of the water redistribution clearly demonstrate that the proper description and modelling of the water budget and runoff pattern in catchments has to include the management effects and their spatial extension. 


\subsection{Introduction}

Forest management practices like thinning, single tree harvesting and clear cutting are creating heterogeneities of the upper boundary of forested sites and landscapes which influence the amounts and distribution of precipitation and energy input. In consequence the dynamic of the soil water is influenced as well. Both, the boundary and the initial conditions are expected to influence the soil water redistribution especially after extreme hydrological events.

Such exceptional hydrological situations often are associated with storms, which are responsible for a significant part of rainfall. More storm days are predicted in simulations with different forces of future climate compared to pre-industrial time periods (Fischer-Bruns et al., 2005) and hence more often extreme hydrological conditions are anticipated. Enhancement of extreme cyclone intensities over Western Europe (Pinto et al., 2007) and important water cycle changes with global warming are resumed by Hansen et al. (2007). On the other hand the sudden influx of warm air masses in winter time, can lead to a rapid snow melt with high infiltration rates. Redistribution patterns may affect the young and old growth forest, if the root systems were low and notable amounts in water were dislocated below the rooting zone. So there should be a focus on soil water redistribution processes.

The aim of the study is to demonstrate the different pattern of redistribution of soil water under a closed forest canopy and under clear cut conditions after a rapid snow melt and a storm following an extensive drought spell in summer.

\subsection{Site, Materials and Methods}

\subsubsection{Site description}

The two sites studied (Otterbach, 51 ${ }^{\circ} 46^{\prime} \mathrm{N}, 9^{\circ} 27^{\prime} \mathrm{E}$ ) are located about $60 \mathrm{~km}$ Northwest of Göttingen in the Solling mountain range at an altitude of $310 \mathrm{~m}$ above sea level. In average this area receives $900 \mathrm{~mm}$ of precipitation per year and has a mean annual temperature of $7.4{ }^{\circ} \mathrm{C}$. The surface slightly inclines to the Northeast. Its soil has been developed in a 60-90 cm (on average) loess layer overlying a Triassic sandstone which forms a compacted solifluction layer. The soil is classified as a Dystric Cambisol. Till 2003 the area completely was covered with spruce (Picea abies), 80 years old. In 2003 a small clear cut was performed on a square of $120 \times 120 \mathrm{~m}$. For this study we have chosen the cleared site (I) and the adjacent undisturbed forest (II). The texture and chemical properties of the mineral soils are given in Table 5-1. Both sites did not differ significantly. However, the clear cut exhibits a higher compaction over the whole profile. Both soils have a moder-type forest floor of $5 \mathrm{~cm}$ thickness. The soils are well structured and in the clear cut the soil still contains the roots of the felled trees and older root channels. 
Table 5-1: $\quad$ Soil properties of the investigation area divided in the cleared site (Plot I) and the undisturbed forest (Plot II)

\begin{tabular}{llcccccccrc}
\hline Plot & $\begin{array}{l}\text { Depth } \\
\mathrm{cm}\end{array}$ & Clay Silt & Sand & $\begin{array}{c}\mathrm{pH} \\
\left(\mathrm{H}_{2} \mathrm{O}\right)\end{array}$ & $\begin{array}{c}\mathrm{C} \\
\mathrm{g} \mathrm{kg}^{-1}\end{array}$ & $\begin{array}{c}\mathrm{CEC}^{\mathrm{a}} \\
\mathrm{mmol}_{\mathrm{c}} \mathrm{kg}^{-1}\end{array}$ & $\begin{array}{c}\mathrm{BS}^{\mathrm{b}} \\
\% \mathrm{CEC}\end{array}$ & $\begin{array}{c}\rho^{\mathrm{c}} \\
\mathrm{g} \mathrm{cm}^{-3}\end{array}$ & $\begin{array}{c}\mathrm{GPV} \\
\%\end{array}$ \\
\hline $\mathrm{I}$ & $0-5$ & 11 & 80 & 9 & 3.5 & 42.6 & 80 & 10 & 0.5 & 58.5 \\
& $20-25$ & 14 & 79 & 7 & 4.2 & 14.4 & 32 & 11 & 1.29 & 51.3 \\
$\mathrm{II}$ & $55-60$ & 17 & 74 & 9 & 4.2 & 3.0 & 45 & 12 & 1.54 & 40.1 \\
& $0-5$ & 11 & 82 & 7 & 3.6 & 62.5 & 84 & 12 & 0.3 & 66.0 \\
& $20-25$ & 14 & 80 & 6 & 4.4 & 15.2 & 34 & 10 & 1.0 & 58.5 \\
& $55-60$ & 12 & 83 & 5 & 4.3 & 5.0 & 62 & 11 & 1.19 & 52.1 \\
\hline
\end{tabular}

${ }^{a}$ Cation Exchange Capacity extraction with $1 \mathrm{M} \mathrm{NH}_{4} \mathrm{Cl}$

${ }^{\mathrm{b}}$ Base Saturation (sum of $\mathrm{Na}, \mathrm{K}, \mathrm{Ca}$ and $\mathrm{Mg}$ as $\%$ of $\mathrm{CEC}$ )

'dry bulk density from fitting Eq.5-1

\subsubsection{Instrumentation and data processing}

Two sites were equipped in the same way for automated continuous monitoring of the soil temperatures, water content and matric potentials. Current supply was provided by solar panels and data were sent to the lab via mobile network transmission. Precipitation continuously was measured with a heated rain gauge in the middle of the cleared site. Snow water equivalent periodically was determined by means of a snow probe. PT 100-thermometers were installed $5 \mathrm{~cm}$ above the forest floor and in 10, 20 and $50 \mathrm{~cm}$ depth. For the monitoring of the matric potential in 20 and $60 \mathrm{~cm}$ depth pressure transducer tensiometers (Honeywell PC2G) were used with six replicates in each depth. Before insertion the tensiometers were calibrated in the lab. After insertion the soil around the tubes was compacted and the tubes were assembled with waterproof silicon discs to prevent water run-down the tubes. Soil water content was measured with $\mathrm{ECH}_{2} \mathrm{O}$ probes (Model EC-20, Decagon). Three of the $20 \mathrm{~cm}$ long, $2.5 \mathrm{~cm}$ wide and $1.2 \mathrm{~mm}$ thick probes were horizontally inserted in 20 and $60 \mathrm{~cm}$ depth in a wall from a shallow pit, which was refilled subsequently. The insertion was carried out very carefully by forming a slit in the soil with a steel blade having the same size as the probe. Before installation, the probes were tested and calibrated extensively under controlled conditions.

For statistical procedures the package R (R Development Core Team, 2005) was used.

To test the $\mathrm{ECH}_{2}$ Oprobes three kinds of dry solid materials were used:

- Glass plates to test the influence of the surrounding of the probes

- two plates of marble, $2 \mathrm{~cm}$ thick and two plates of granite, $2 \mathrm{~cm}$ thick - to test different materials.

In each case the $\mathrm{ECH}_{2} \mathrm{O}$ probe was inserted flat between the plates or stacks of plates. Moreover we used granular solid materials with different water contents:

- Glass beads, $0.75-1.0 \mathrm{~mm}$ in diameter and

- Soil material from the field sites, from 10 to $60 \mathrm{~cm}$ depth, air dried, crushed and sieved through $2 \mathrm{~mm}$ mesh. 
Further, to test the influence of the probe-soil-contact on the signal of the probe two porous lime-sand-stone bricks were used. They were arranged in a way to leave a slit of different size between them. In this slit the $\mathrm{ECH}_{2} \mathrm{O}$ probe was inserted.

Water retention curves of the soil in 20 and $60 \mathrm{~cm}$ depth were measured as desorption curves by a combination of a suction plate (up to $300 \mathrm{hPa}$ ) and a pressure plate (up to $15000 \mathrm{hPa}$ ). Five replicates were used for each site and each depth. The results were summarized using the van Genuchten equation (formula 5-1, van Genuchten et al., 1991) with $\theta r=0$ and $m=1-1 / n$ :

$$
\theta=\theta \mathrm{s} /(1+|\alpha \mathrm{h}| \mathrm{n}) \mathrm{m}
$$

Where $\theta$ is the volumetric water content and $\mathrm{h}$ is the applied pressure. $\theta \mathrm{s}$ is the saturated water content and $\mathrm{n}, \mathrm{m}$, and $\alpha$ are empirical parameters. The parameters were obtained by a nonlinear least-square-fitting (procedure nls in R). The fitted parameter $\theta$ s was used to obtain bulk densities using a mineral density of $2.65 \mathrm{~g} \mathrm{ml}^{-1}$ (Tab. 5-2).

Table 5-2: $\quad \mathrm{ECH}_{2} \mathrm{O}$ signals in different materials in \% of supply voltage [ $\left.\mathrm{V}-1 * 100\right]$

\begin{tabular}{lc}
\hline Material & $\begin{array}{c}\text { Signal } \\
\text { [\% supply voltage] }\end{array}$ \\
\hline Air & 9.9 \\
Water, demineralised & 38.8 \\
Water, $1 \mathrm{mM} \mathrm{AICl} 3$ & 38.0 \\
Granite, $2 \mathrm{~cm}$ & 19.5 \\
Marble, $2 \mathrm{~cm}$ & 21.5 \\
Glass, $2 \mathrm{~cm}$ & 20.7 \\
\hline
\end{tabular}

\subsection{Results and Discussion}

\subsubsection{Calibration of the Capacitor dielectric surrounding sensor}

Table 5-2 shows, that the $\mathrm{ECH}_{2} \mathrm{O}$ signal clearly is different in air, water and solid materials, respectively. However, the solid materials exhibit fairly constant values. To test weather the electrolyte content of the soil solution may influence the signal, we included a $1 \mathrm{mM} \mathrm{AlCl}_{3}$ solution in our tests, representing the ions and concentrations expected in the field soil. The difference to demineralised water is about $2 \%$ and small compared to other sources of variance. Because Czarnomski et al. (2005) found that the influence of temperature on $\mathrm{ECH}_{2} \mathrm{O}$ readings was small (statistically insignificant), we ignored temperature effects in this study. 

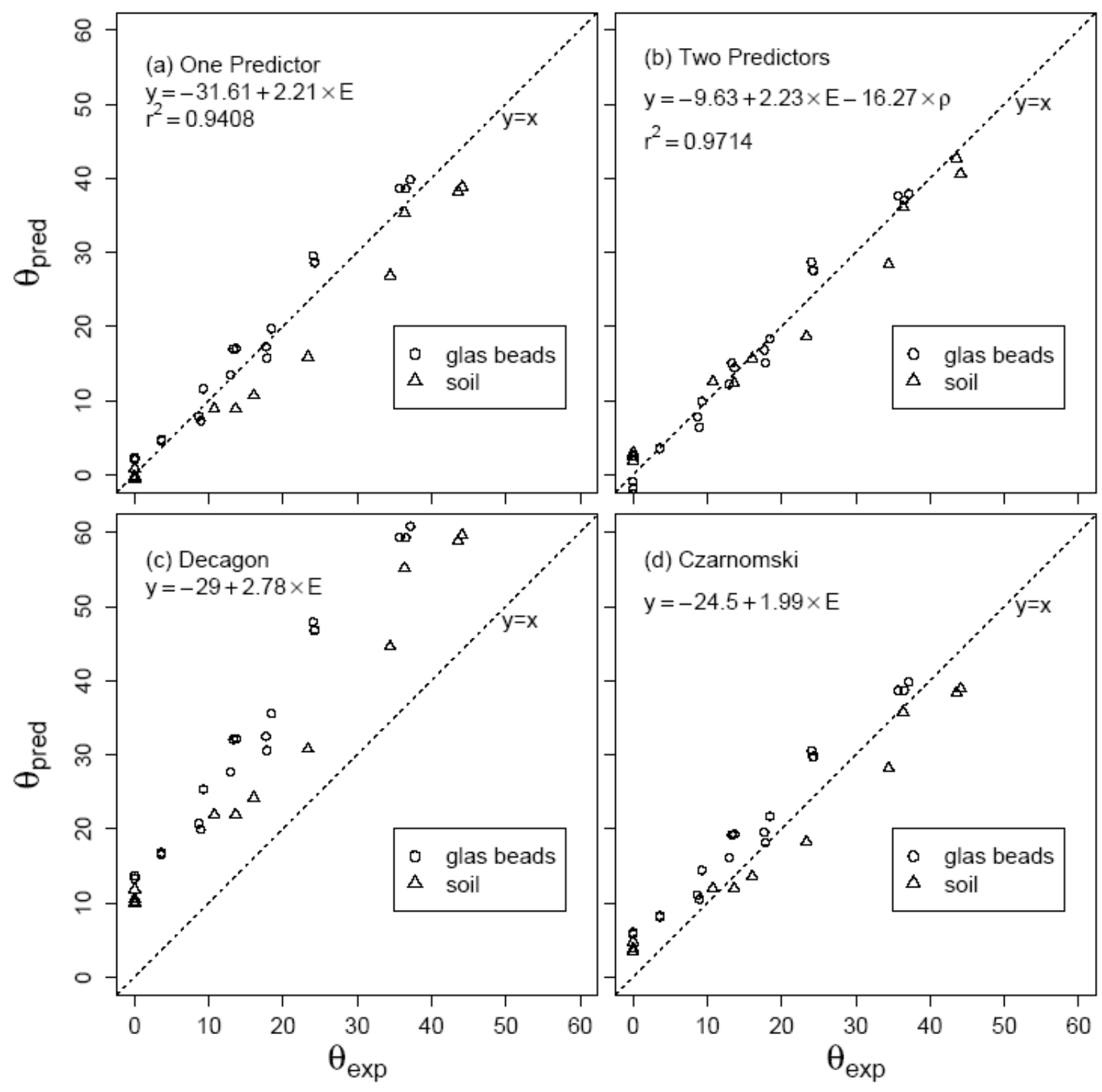

Figure 5-1: Results of $\mathrm{ECH}_{2} \mathrm{O}$ measurements with different mixtures of granular material and water.

Figure 5-1 shows the results of the laboratory calibrations with soil and glass beads. Figure 5-1a shows the prediction forms a linear regression of volumetric water content on $\mathrm{ECH}_{2} \mathrm{O}$ signal $\mathrm{E}$. The model can be improved by including the bulk density (5-1b). While in diagram 5-1a the data points for soil and for glass beads occupy different domains, calling for distinct calibration functions of the two materials, this difference disappeared in the two predictor model (5-1b). The regression factor with 0.97 is statistically highly significant (t-distribution, $p<0.01$ ). Figure $5-1 \mathrm{c}$ shows that the standard calibration line as suggested by Decagon (2006) does not fit our data. While good agreement (5-1d) was found with the calibration function of Czarnomski et al. (2005). 


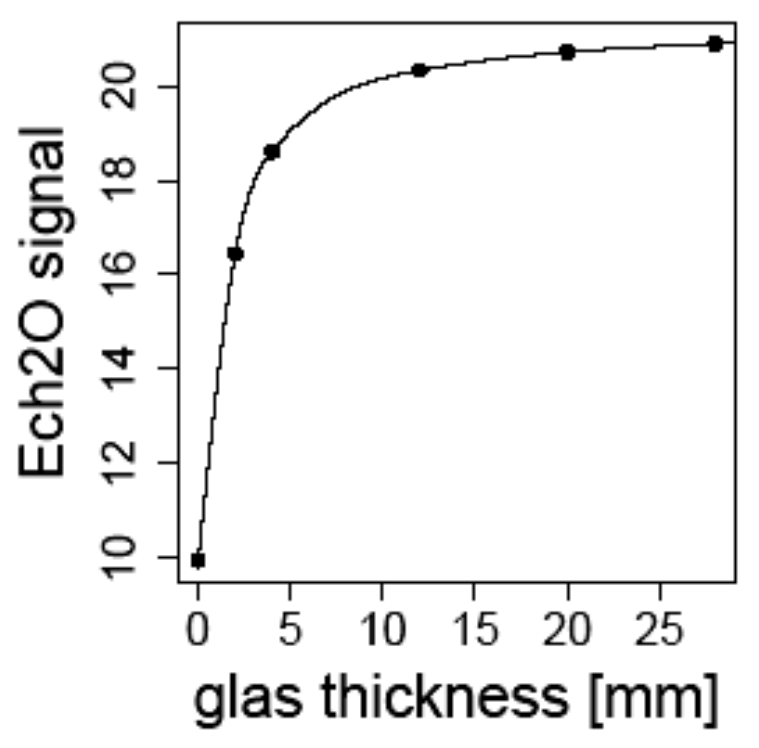

Figure 5-2: $\quad$ Signal of an $\mathrm{ECH}_{2} \mathrm{O}$ probe between glass stacks of different height (same below and above the probe). Points are measurements; the line is an interpolating spline function.

Figure 5-2 indicates that $2 \mathrm{~mm}$ of glass already give about $80 \%$ of the signal obtained from $20 \mathrm{~mm}$ plates. This indicates that the immediate vicinity of the probe has a large impact on the signal. In consequence this may create problems under field conditions, where one has to form a slit in the soil in order to insert the $\mathrm{ECH}_{2} \mathrm{O}$ probe. Inevitably, gaps will remain between the probe and the soil, influencing the signal. Also shrinking of the soil may change the contact between probe and soil. The effect was demonstrated with bricks forming slits of different width. The bricks used had a pore volume of $31 \%$ and volumetric water content of $1 \%$ when dry and of $25 \%$ when wet.

The effect of the slit width is large (Fig. 5-3). A $0.4 \mathrm{~mm}$ slit on each side reduces the signal by $5.2 \%$ supply voltage (wet) and by $2.3 \%$ (dry). According to our calibration (Fig. 5-1) this leads to an underestimation of the water content of 11 or 5 vol. \%.

For the determination of the soil water content with the probes tested the mineral composition of the soil is of less importance. However, the ratio of solid material to air, which directly is related to bulk density of soil at given bulk water content, has to be regarded. 
There is also an uncertainty in using the lab calibration to describe the change in water content, because of the non controlled probe/soil contact in field. To avoid negative effects caused by the insertion of the probes we carried out in situ calibrations, for adaptation of our lab curves (Fig. 5-4).

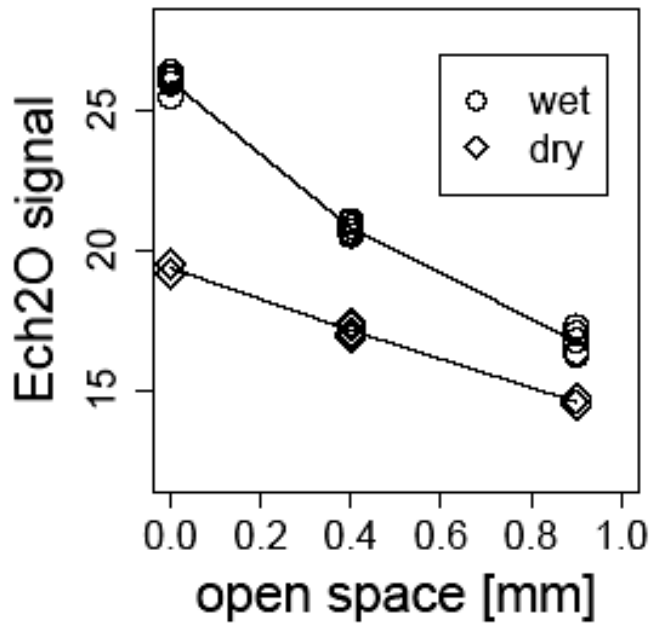

Figure 5-3: $\quad$ Effect of a gap between $\mathrm{ECH}_{2} \mathrm{O}$ probe and two lime-sand-stone bricks. Indicated is the average gap on each side of the probe. Points represent repeated insertions of the probe. Lines connect means.

\subsubsection{Soil moisture redistribution of two extraordinary hydrological events}

To study the pattern of water redistribution in soil under extreme conditions, we used two periods. The first period was a rapid snow melting after a longer frost period in spring 2006, where the air temperature rose by $14^{\circ} \mathrm{C}$ within 24 hours leading to the rapid melting of the snow pack.

In March 2006 the amount of snow packed on the soil differed between both sites. It was $29 \mathrm{~mm}$ (water equivalent) under the forest canopy and $45 \mathrm{~mm}$ on the clearing. The difference is explained by evaporation of intercepted snow from the spruce canopy. Snowfall in 2006 occurred after a longer frost period without precipitation therefore the soil was frozen and stayed frozen between down to 10 and $20 \mathrm{~cm}$ depth until snow melt, during which the soil thawed.

The soil was wetter at the cleared site by about $6 \%$ at $20 \mathrm{~cm}$ depth and was dryer about $4 \%$ at $60 \mathrm{~cm}$ depth (Fig. 5-5 and 5-6). At the closed canopy site reaction to snow melt was swift. Immediately after air temperature rose above zero matric potential in the upper soil also rose. The effect was propagated within one day to $60 \mathrm{~cm}$ depth (Fig. 5-5). The water content showed the same pattern and the effect of the recharge on the subsoil was low. 

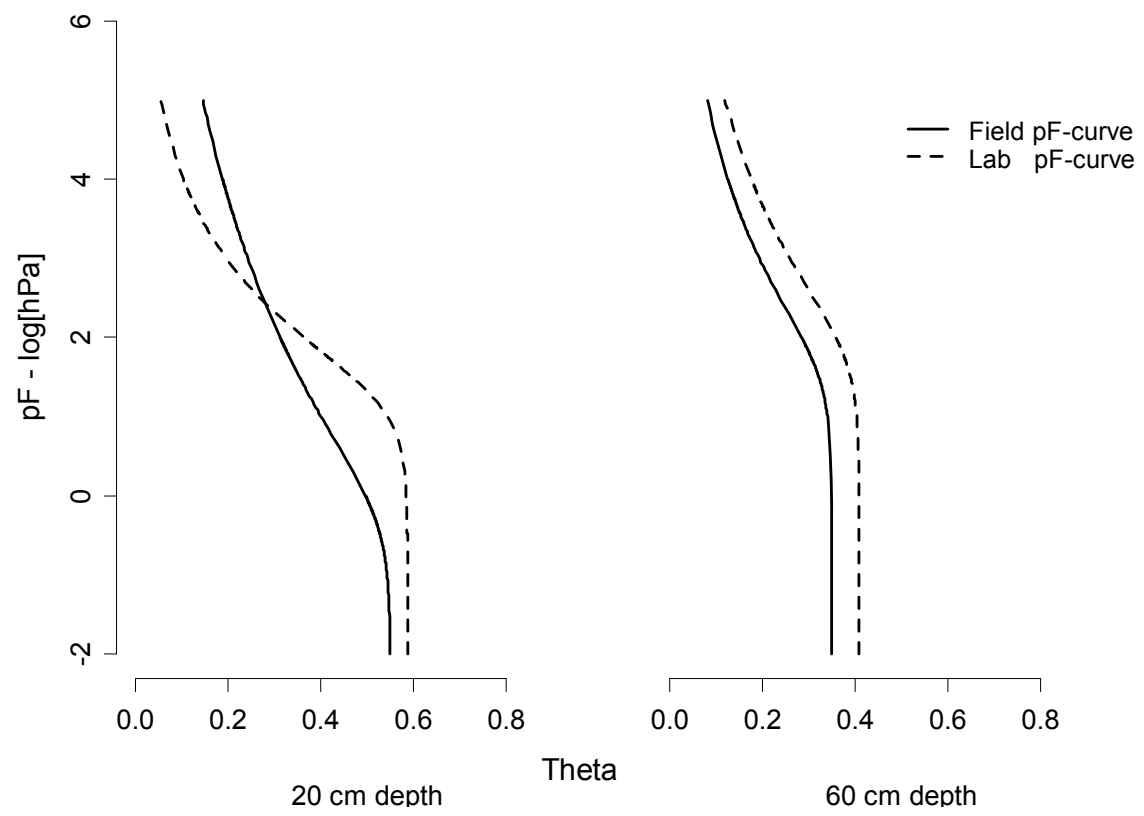

Figure 5-4: Comparison between water retention curves derived from laboratory (desorption curve, dashed line) and from field data (solid line) for $20 \mathrm{~cm}$ (left) and $60 \mathrm{~cm}$ depth (right).

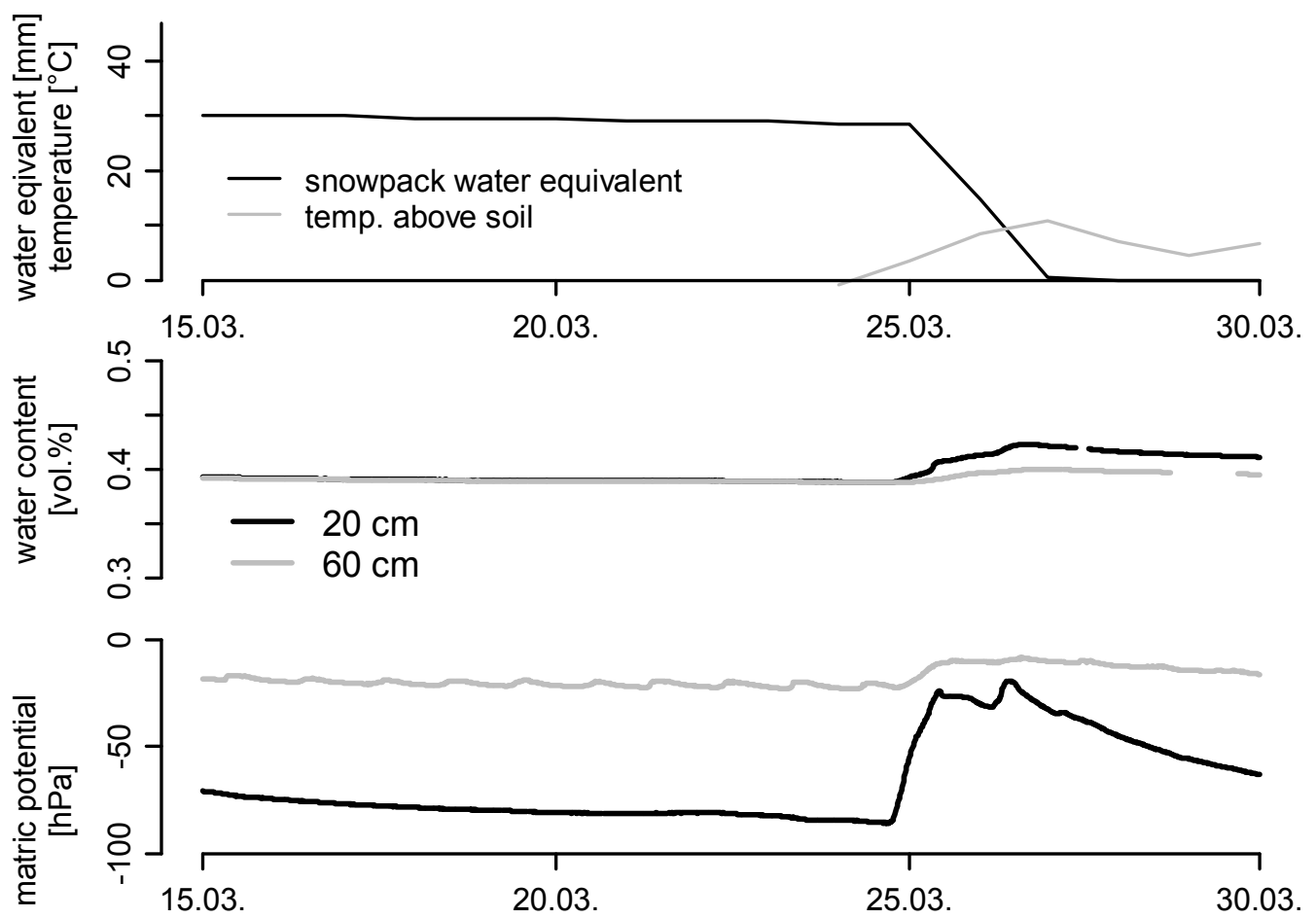

Figure 5-5: Development of the snowpack water equivalent (solid line), the soil water content and soil water tension in 20 and $60 \mathrm{~cm}$ depth during snowmelt in March 2006 under closed canopy. 
At the cleared site the tensiometers at $20 \mathrm{~cm}$ depth exhibited some short impulses in matric potential prior to temperature rise. This was an effect of the solar radiation inducing some snow melt before the ambient temperature rose above the melting point. Due to the high matric potential and high water saturation the changes in water content were small and therefore the effect was not detected by the $\mathrm{ECH}_{2} \mathrm{O}$ probes. Rise of matric potential with changes in water content becomes important almost immediately after snow melt. Increase in water content took place more rapidly at $60 \mathrm{~cm}$ depth than at the upper soil layer at the cleared site (Fig. 5-6).
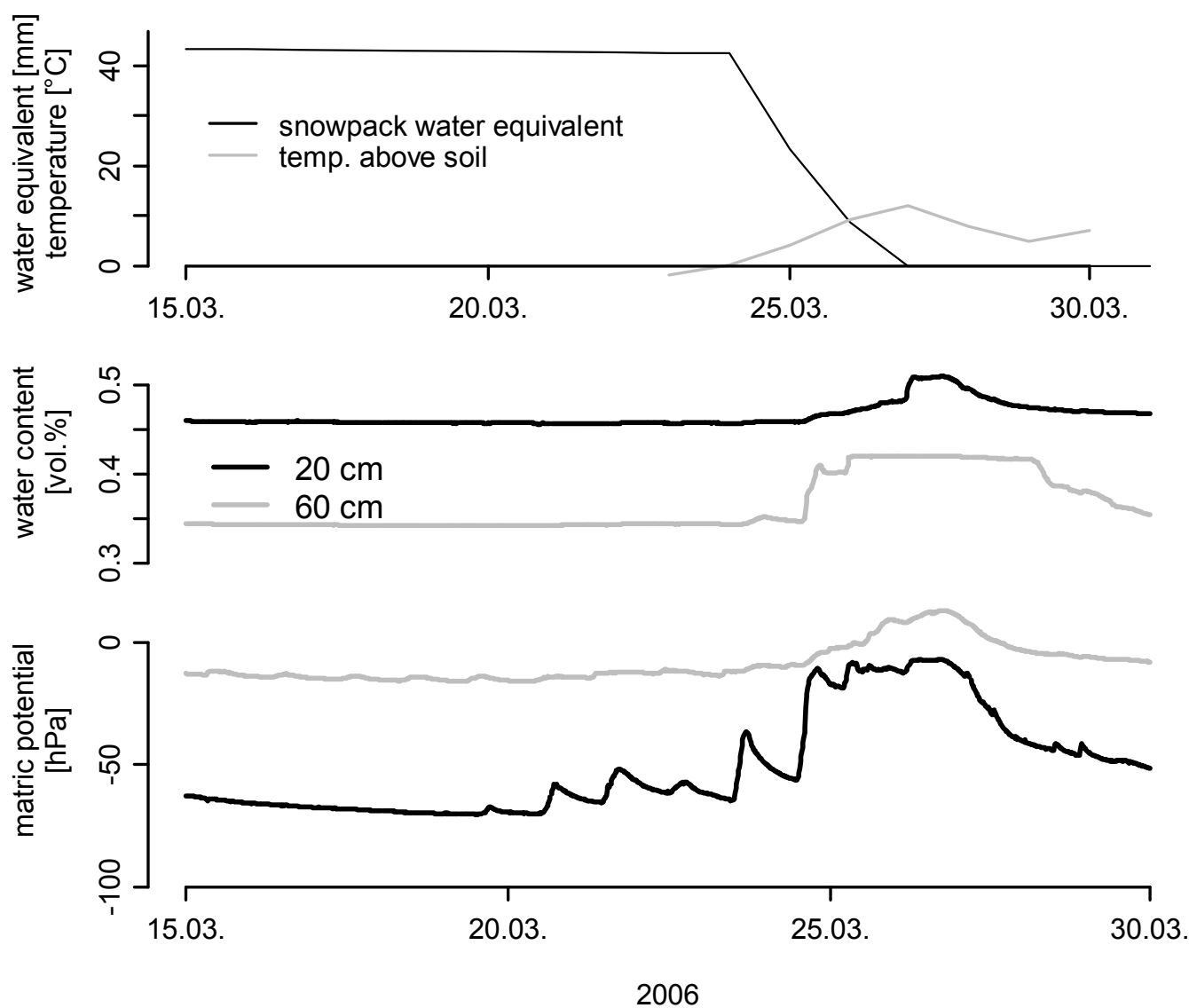

Figure 5-6: Development of the snowpack water equivalent (solid line), the soil water content and soil water tension in 20 and $60 \mathrm{~cm}$ mineral soil during snowmelt in March 2006 at the cleared site.

The figures show that at both sites the water reached deeper soil layers against an upward hydraulic gradient indicating a non-Darcy flow of melt water bypassing the bulk soil. The effect of bypass flow is more pronounced on the cleared site where even free water appears in $60 \mathrm{~cm}$ depth for some days. The difference to the stand can be attributed to higher water input at the cleared site (in snowpack and in soil water) before snowmelt and higher saturation of the soil. These findings are consistent with the observations of Tymchak and Torres (2007) under a mixed Pinus-Quercus stand on a sandy soil. They found a switch of wetting velocity with rainfall intensity and they speculated that the switch is related to the initiation of preferential flow. Because frozen soils do not impede infiltration and the infiltration rate is determined by snow 
melt rate (Iwata et al., 2008), it is obvious in our case that the preferential flow was more pronounced as long the upper part of the soil was frozen and water flow was restricted to macropores and root channels. This is consistent with the finding, that water redistribution pattern differs (Iwata et al., 2008) depending if the topsoil is frozen when the snow cover builds up or not.

The second period describes the soil water redistribution after a severe drought spell of two months. Bulk precipitation within two weeks amounted $195 \mathrm{~mm}$ in August 2006. $27 \%$ of this went into interception evaporation at the closed canopy site, which is in accordance with the value of $30 \%$ found by Benecke (1984) for the Solling area. At both sites initial water contents and matric potentials differed notably among the layers. Under closed canopy the bottom layer had about $13 \%$ higher volumetric water content and about $600 \mathrm{hPa}$ lower matric potential, whereas at the cleared site the bottom layer had lower volumetric water content than the surface layer (Figure 5-7 and $5-8)$. This is explained by the difference in transpiration and interception.

Under the closed canopy, top soil matric potentials raised for 7 days. Reaction of water content in $20 \mathrm{~cm}$ depth was first observed when precipitation exceeded $10 \mathrm{~mm}$ per day on August 17th (Fig. 5-7). Water content in $60 \mathrm{~cm}$ depth inclined gently and became notable after August 20th when differences in matric potentials were no longer existent. So the reaction of subsoil to rain events was less pronounced and indicated a retarded and very continuous flow and water redistribution.

In contrast at the cleared site matric potentials in $20 \mathrm{~cm}$ depth reacted on the first day precipitation exceeding $10 \mathrm{~mm}$ (Fig. 5-8). Reaction of water contents in topsoil and bottom layer occurred on the same date (August 17th), which even was the date the water content under closed canopy reacted initially. In consequence water reached the deeper soil layers 5 days earlier on the cleared side than under closed canopy. This signifies shorter contact time of water and the matrix. The pattern observed is characterized by an immediate rise in water potential and a slow decrease afterwards. This is due to a rapid bypass of the dryer soil matrix of the percolating water followed by an uptake of the percolated water into the matrix with low matric potential.

The deeper soil layers on the cleared site also were partially filled up with water against upward hydraulic gradients during the summer storm, but the effects were less pronounced compared to the snow melt. Further, the antecedent differences in matric potentials were low compared to the closed canopy site, owing to the lower prior input. Free water appearance was not observed in contrast to the situation in spring. Comparing the same time span for the summer and the spring event, the water input in summer exceeded that in spring, but had not the same steadiness and intensity within 48 hours as the spring event. Input of the single rain events and time lack between them in summer obviously did not exceed the hydraulic conductivity of the deeper soil layers, which is why free water did not occur. 


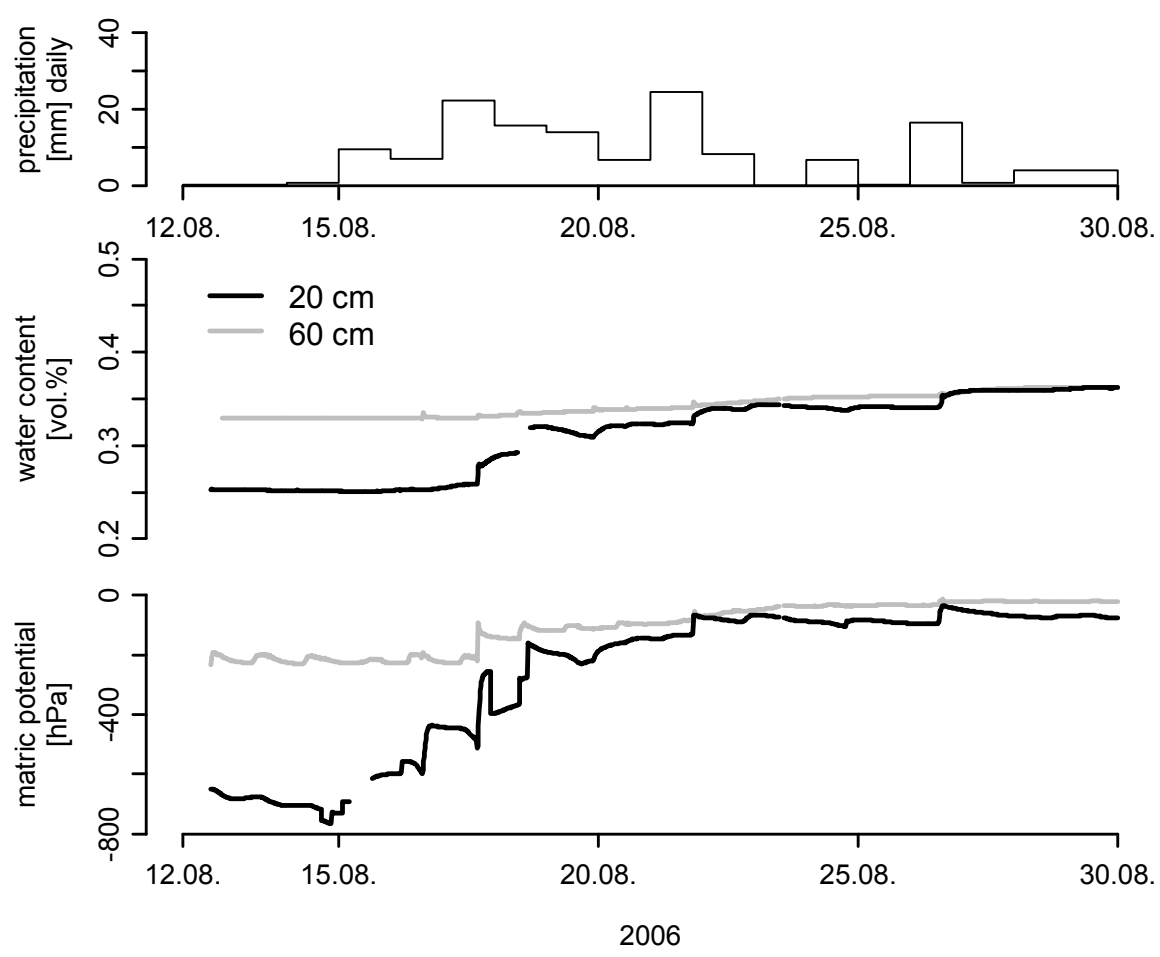

Figure 5-7: Development of precipitation (top), the soil water content (middle) and soil water tension (bottom) in 20 and $60 \mathrm{~cm}$ mineral soil during summer storm in August 2006 under closed canopy.
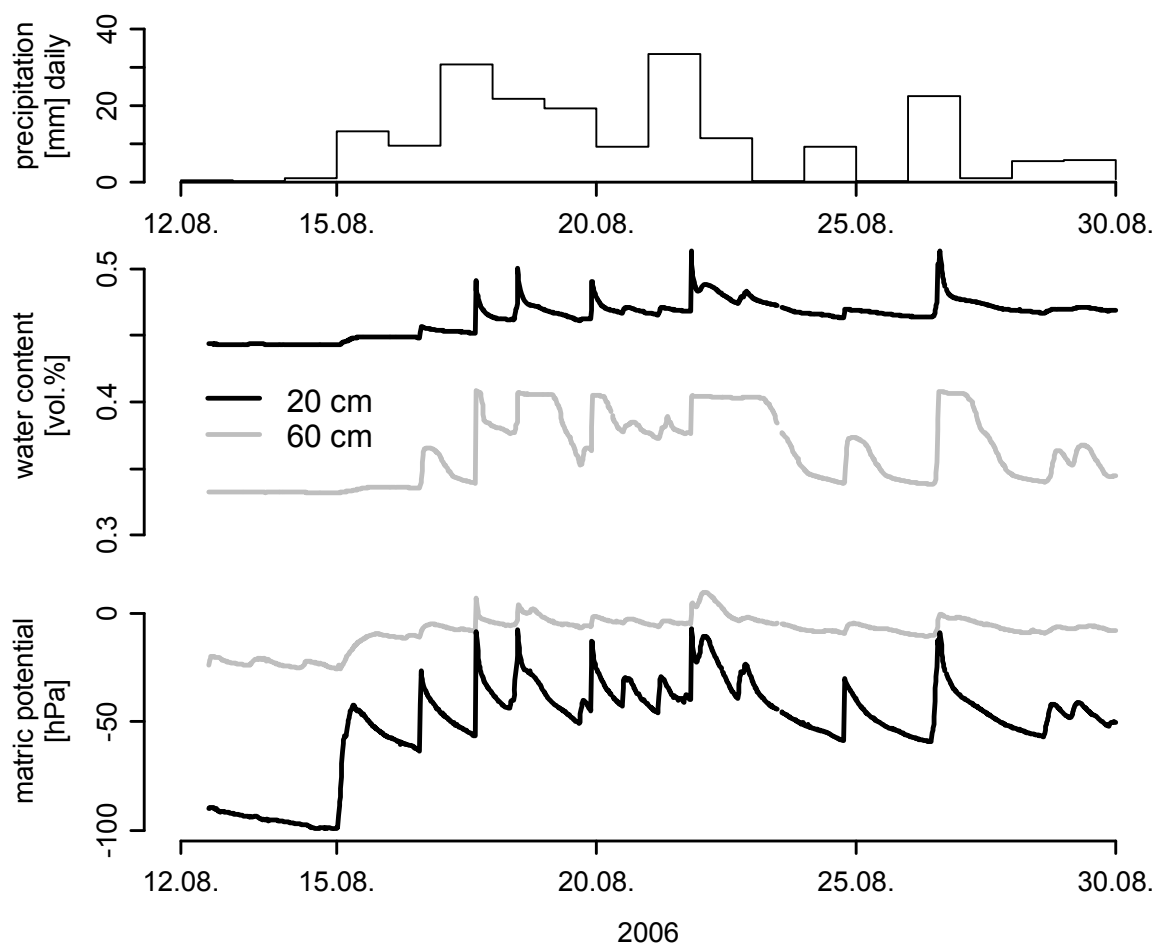

Figure 5-8: Development of precipitation (top), the soil water content (middle) and soil water tension (bottom) in 20 and $60 \mathrm{~cm}$ mineral soil during summer storm in August 2006 at the cleared site. 
The decrease of the soil water tension in a forest soil profile without building up of a wetting front after rain events is in agreement with previous studies, using tensionmeters (Göttlein and Manderscheid, 1998) or TDR probes (Jost et al., 2004) under Norway spruce stands. Water enters the subsoil layers by preferential pathways like macropores. The macropores were reached laterally due to a small-scale runoff discharge as a result of hydrophobic reaction of the surface layer (Kim et al., 2005). Hence microrelief can cause spatial heterogeneities of water redistribution (Doerr et al., 2006). Permanent vegetated soils in humid climate exhibit water repellence as most affected soils elsewhere in the world (Doerr et al., 2006). Water repellence occurred independent from tree species in soils under pure and mixed stands in the upper $20 \mathrm{~cm}$ (Wöllecke, 2006) and seasonal variability largely overshadowed variations between stands (Buczko et al, 2005). The highest values of persistence and degree of hydrophobicity were reached in the summer months (Buczko et al., 2005) and during extended dry periods (Crockford et al. 1991, Ritsema and Dekker, 1994). Changes of quality in the highly hydrophobic organic matter during seasons and stronger adhesion of the organic matter to the mineral soil surfaces were discussed by the cited authors as reasons. Further, water repellence increases with decreasing $\mathrm{pH}$-value (Lin et al. 2006). Due to higher drying and wetting dynamics on the cleared site and the lower $\mathrm{pH}$ value in the topsoil (Tab. 5-1), enhanced water repellence can be assumed for the clearing compared to the closed canopy site.

As a consequence of water repellency the top soil matric infiltration rates are reduced (Doerr et al., 2005). The intensity is influenced by the initial water content (Grelewicz and Plichta, 1985; Greiffenhagen et al., 2006). For instance at permanently vegetated soils in UK a threshold of $28 \%$ volumetric water content (Doerr et al., 2006) for water repellency was found, above this threshold water repellency does not occur. The water content indicates water repellency under the closed canopy at the beginning of the summer storm. The measurements in $20 \mathrm{~cm}$ depth however show that bypass flow was severe. Therefore the effect of water repellence was not complete and lateral water flow followed by redistribution must be enhanced.

Despite the higher water input during the summer storm, free water was not present in the profile at any of the two sites during the storm in contrast to the melting episode. Apart from temporal water input distribution, in winter the water storage capacity of the soil was lowered by the amount of the frozen soil layer. During the winter months both sites had in spite of a similar wetting history different redistribution pattern, which are controlled by the amount of water input. In contrast during summer months the rewetting patterns of the surface layers were different in spite of similar water inputs.

The area of microcatchments around preferential flow paths are an important boundary also, since biopores for instance can increase infiltration rates by a factor 2-3 (Meek et al., 1989). Such channels create not only high flow rates but further large 
heterogeneity (Newmann et al., 2004; Jarvis, 2007), what hardly enables exact modelling of water and solute fluxes at forest stand scales. Root numbers determined at submontane Spruce stands demonstrate the dimension of possible additional pathways of converted forests. Within the upper $50 \mathrm{~cm}$ of a $10 \mathrm{~m}$ long pitch at three submontane Spruce stands 476,367 and 426 roots of the class 2-10 $\mathrm{mm}$ in diameter were counted (Xu, 1991).

The data measured in the Solling area lead to the assumption, that the process of preferential flow and the effect to water redistribution were different at the two events. The initial water tension regulates the depth of bypassing (cf. Jost et al., 2004), which itself is regulated by the hydraulic history. In our example of increasing water tension in the upper layer from both sites in spring over the clear cut in summer to closed canopy site in summer is reducing the bypass flow.

For the cleared site within the spring event this effect might be overlapped by a partial ice barrier. When the snowmelt started the soil was partly frozen. Therefore the preferential downward movement of water into the open macropores was enhanced. For the assessment of seasonal and annual patterns of the water budgeds it is not essential to consider the bypassflow as shown in chapter 4 (Fröhlich et al., 2009), but with respect to solution redistributions the applicability of multi-domain approaches (Tuller and Or, 2002) should be regarded. At the clear cut site the described effects on water redistribution is especially important for the initial phase after clear cutting, when high loads of nitrogen in the seepage water was observed by several authors (for example: Katzensteiner, 2003; Nohrstedt et al., 1994; Dahlgren and Driscoll, 1994).

\subsection{Conclusions}

Soils with comparable hydraulic functions, water retention curves and hydraulic conductivities, can react on events with rapid water input completely different. This is attributed to the vegetation, which on the one hand side modifies the amount of precipitation via interception and on the other hand side the transpiration, which determines the water content of the soil. Furthermore the energy input to the soil is modified by the vegetation cover, which influences the melting process of the snow cover or the degree of higher hydrophobicity of the organic layer.

These factors generate different initial degrees of water saturation and hydrophobic surfaces and affect the infiltration process. For the description and modelling of water balances of catchments this means the differently managed areas have to be described by different initial states, driving forces and processes. This is especially necessary for landscapes and periods with highly variable precipitation for example snowmelts or storm events. Initial soil moisture content is an important regulating factor for the occurrence and intensity of preferential flow, which highly is influenced by the hydraulic and thermal history of the site as well as the infiltration rates. 


\section{Acknowledgments}

We would like to thank the 'Deutsche Forschungsgemeinschaft' (DFG) for supporting this work within the project BE 713 / 27-1.

\subsection{References}

Benecke, P.: Der Wasserumsatz eines Buchen- und eines Fichtenwaldökosystems im Hochsolling. J.D. Sauerländer's Verlag Frankfurt am Main, 1984.

Buczko, U., Bens, O., Hüttl, R.F.: Variability of soil water repellency in sandy forest soils with different stand structure under Scots pine (Pinus sylvestris) and beech (Fagus sylvatica). 2005, Geoderma, 126,317-336.

Crockford, S., Topalidis, S., Richardson, D.P.: Water repellency in a dry sclerophyl eucalypt forest measurements and processes. 1991, Hydrological processes, 5, 405-420.

Czarnomski, N. M., Moore, G. W., Pypker, T. G., Licata, J., and Bond, B. J.: Precision and accuracy of three alternative instruments for measuring soil water content in two forest soils of the Pacific Northwest, Can.J.For.Res, 35, 1867-1876, 2005.

Dahlgreen, R.A., Driscoll, C.T.: The effects of whole-tree clear-cutting on soil processes at the Hubbard Brook Experimental Forest, New Hampshire, USA. 1994, Plant and Soil (158), 239-262.

Decagon: $\mathrm{ECH}_{2} \mathrm{O}$ Soil Moisture Sensor - Operator's Manual - For Models EC-20, EC-10, and EC-5, Decagon Devices, Inc, Pullman WA 99163 USA, 2.1 edn., http://www.decagon.com, 2006.

Doerr S.H., Shakesby R.A., Dekker L.W. Ritsema C.J.: Occurrence, prediction and hydrological effects of water repellency amongst major soil and land-use types in a humid temperate climate. 2006, European Journal of Soil Science 57, 741-754.

Doerr S.H., Douglas P., Evans R.C., Morley C.P., Mullinger N.J., Bryant R., Shakesby R.A.: Effects of heating and post-heating equilibration times on soil water repellency. 2005, Australian Journal of Soil Research 243 (3), 261-267.

Fröhlich D., Klinck U., Radler K., Beese F.: Räumliche Modifikationen des Bodenwasserhaushalts durch Kahlschlag. 2009. In: Raumzeitliche Dynamik der Parameter des Energie-, Wasser- und Spurengashaushalts nach Kleinkahlschlag, Dissertation.

Göttlein A., Manderscheid B.: Spatial heterogeneity and temporal dynamics of soil water tension in a mature Norway spruce stand. Hydrological Processes 12, 1998, 417-428.

Greifenhagen, A., Wessolek, G., Facklam, M., Renger, M., Stoffregen, H.: Hydraulic functions and water repellency of forest floor horizons on sandy soils. Geoderma, 132, 2006, 182-195.

Grelewicz, A., Plichta,W.: Water absorption in samples of different types of forest humus. Forest Ecology and Management, 10, 1985, 1-11.

Iwata, Y., Hayashi, M., Hirota, T.: Comparison of snowmelt infiltration under different soil-freezing conditions influenced by snow cover. 2008, Vadose Zone Journal, 7, 79-86. 
Jarvis N.J.: A review of non-equilibrium water flow and solute transport in soil macropores: principles, controlling factors and consequences for water quality. European Journal of Soil Science 58, 2007, 523-546.

Jost, G., Schume, H., Hager, H.: Factors controlling soil water-recharge in a mixed European beech (Fagus sylvatica L.)-Norway spruce [Picea abies (L.) Karst.] stand. European Journal of Forest Research 123, 2004, 93-104.

Katzensteiner, K.: Effects of harvesting on nutrient leaching in a Norway spruce Picea abies Karst.) ecosystem on a Lithic Leptosol in the Northern Limestone Alps. 2003, Plant and Soil (250), 59-73.

Kim,H.J., Sidle, R.C., Moore, R.D.: Shallow lateral flow from a forested hillslope: Influence of antecedent wetness. Catena 60, 2005, 293-306

Lin, C.Y., Chou, W.C., Tsai, J.S., Lin, W.T.: Water repellency of Casuarina windbreaks (Casuarina equisetifolia Forst.) caused by fungi in central Taiwan. 2006, Ecological Engeneering, 26, 283-292.

Meek B.D., Rechel E.R., Carter, L.M., DeTar, W.R.: Changes in infiltration under alfalfa as influenced by time and wheel traffic. Soil Science Society of America Journal 53, 1989, 238-241.

Newman B.D., Wilcox, B.P., Graham, R.C.: Snowmelt-driven macropore flow and soil saturation in a semiarid forest. Hydrological Processes 18, 2004, 1035-1042.

Nohrstedt, H.-Ö., Ring., E., Klemedtsson, L., Nilsson, Å.: Nitrogen losses and soil water acidity after clearfelling of fertilized experimental plots in a Pinus sylvestris stand. 1994, Forest Ecol. Managem. (66), 69-86.

R Development Core Team: R: A language and environment for statistical computing. R Foundation for Statistical Computing, Vienna, Austria, http://www.R-project.org, 2005.

Ritsema, C.J., Dekker, L.W.: How water moves in a water repellent sandy soil. 2. Dynamics of fingered flow. 1994, Water resources research, 30, 2519-2531.

Tuller, M., Or, D.: Unsaturated hydraulic conductivity of structured porous media: a review of liquid configuration-based models. 2002, Vadose Zone J., 1, 14-37.

Tymchak, M.P., Torres, R.: Effects of variable rainfall intensity on the unsaturated zone response of a forested sandy hillslope. Water Resources Research, 43, 2007, W06431.

van Genuchten, M. T., Leij, F. J., and Yates, S. R.: The RETC Code for Quantifying the Hydraulic Functions of Unsaturated Soils, Tech. rep., U.S. Salinity Laboratory, U.S. Department of Agriculture, Agricultural Research Service, Riverside, California 9250 1, 1991.

Wöllecke, B.: Einfluss con Acker und Waldnutzung auf Wasseraufnahme und Wasserspeicherung von Löss und Sandböden. 2006, Cottbuser Schriften, 35.

Xu Y.:Ökologische Grundlagen für den Anbau der Großen Küstentanne (Abies grandis Lindl.) auf vernässten Böden. Berichte des Forschungszentrums Waldökosysteme, 1991. 


\section{Schlussfolgerungen}

Die Untersuchung des ökophysiologischen Verhaltens von größeren Freiflächen im Wald ist in den vergangenen Jahren weitgehend vernachlässigt worden. Die Ursache dafür kann in der gegenwärtigen waldbaulichen Zielsetzung gesehen werden, die vom altersgleichen Bestandstyp - der auf dem Kahlschlag basiert - abgeht und strukturierte Mischbestände anstrebt. Dabei gibt es dringende Gründe, sich mit der Lückenproblematik im Wald zu befassen. Sei es die Schaffung von Kleinkahlschlägen zur Begründung von Lichtbaumarten oder zur Vornutzung mit schnell wachsenden Baumarten, sei es zur Aufforstung von Sturmflächen oder von Bestandslücken, die durch Schädlingskalamitäten entstanden sind.

Die Sichtung der Literatur hat ergeben, dass zur Beantwortung drängender Fragen nach dem Energie-, Wasser- und Stoffhaushalt derartiger Bestandslücken das vorhandene Wissen nicht ausreicht. Besonders dann nicht, wenn es sich um die räumliche und zeitliche Dynamik von Umsetzungs- und Transformationsprozessen handelt, wie sie in räumlich begrenzten Lücken auftritt. Es zeigt sich, dass die an Großkahlschlägen gewonnenen Erkenntnisse nicht 1:1 übertragen werden können und dürfen. Da dies in der Praxis aber häufig geschieht, hat sich vielfach ein Bild über die ökologische Funktion begrenzter Bestandslücken festgesetzt, zu dessen Berichtigung beigetragen wird.

Die in dieser Arbeit gefundenen Resultate machen deutlich, dass es für viele ökologische und waldbauliche Fragestellungen unumgänglich ist, die Bestandslücken räumlich und zeitlich differenziert anzusprechen und zu bewerten.

Wenn auch der Übergang von der Freifläche zum Altbestand abrupt erfolgt, so gilt dies nicht für den Strahlungsinput, den Wärmehaushalt des Bodens und den Wasserund Stoffhaushalt. Es konnte gezeigt werden, dass die Übergänge stetig sind und mehr oder weniger tief in die Freifläche aber auch in den Altbestand hineinreichen. Es konnte ferner gezeigt werden, dass die dabei auftretenden Gradienten durch die Himmelsrichtung und die Jahreszeit in starkem Maße modifiziert werden.

Mit Hilfe empirischer Modelle konnten die Einflüsse der Bestandsränder auf den Energieinput, die Verteilung der Bodentemperatur und den Wasserhaushalt quantifiziert und flächenhaft dargestellt werden. Die dabei abgeleiteten raum-zeitlichen Muster können nun als Basis für stoffliche Umsetzungen in Böden, aber auch für die Interpretation des Wachstums der gepflanzten Bäume dienen. Die Auswertungen dafür stehen aber noch aus und sind späteren Untersuchungen vorbehalten.

Der Vergleich der Spurengasemissionen zeigte eine erhöhte Freisetzung von Lachgas auf der Kahlschlagsfläche in der initialen Phase gegenüber dem Bestand und der Zielstärkennutzung. Einen sehr großen Einfluss auf die Gesamtemissionen hatten die Rückegassen. Hier besteht ein sehr großes Potential für die Verringerung der Lachgasemissionen nach forstlichen Eingriffen. Die Reduktion der Verdichtung und 
die Vermeidung der Einarbeitung organischer Massen in die Fahrspuren sind Möglichkeiten, um die Lachgasemission zu vermindern.

Im Gegensatz zu den anderen Annahmen weist auch die Zielstärkennutzung eine signifikant erhöhte Lachgasfreisetzung gegenüber dem Bestand auf, so dass bei dieser Hiebform über die Jahre verteilt die gleichen Stickstoffmengen freigesetzt werden könnten, wie in den ersten Jahren auf dem Kahlschlag. Besonders vor dem Hintergrund, dass Emissionen auf Kahlschlagflächen nach einigen Jahren stark abfallen und das Ausgangsniveau erreichen können, bedarf dieser Befund weiterer Untersuchungen.

Eine Reduktion der Methanaufnahme war nur auf der Kahlschlagfläche nachweisbar. Auch hier spielten die Rückegassen eine herausragende Stellung, da auf diesen Flächen sogar Methanemissionen festgestellt wurden. Der Schutz der Atmosphäre durch Böden besteht vielfach darin, eine Netto-Freisetzung von Methan zu verhindern. Diese Funktion des Bodens blieb - wenn auch reduziert - dennoch am Standort Otterbach nach dem Kahlschlag erhalten.

Die Rückkopplung zwischen hiebinduzierten Reduktionen der Methanaufnahme und der Stauwasserdynamik bedarf jedoch weiter reichender Überprüfungen, insbesondere da derartige Verhältnisse in den höheren Kammlagen der Mittelgebirge häufig zu finden sind, die sich in der Regel durch hohe Niederschläge auszeichnen.

Bezüglich der Umweltbedingungen auf einer Kahlschlagfläche konnte gezeigt werden, dass die Ränder einen bedeutenden Flächenanteil einnehmen und auch den angrenzenden Bestand bis zu 60 m beeinflussen können.

Für den von der Freifläche beeinflussten Altbestand wirkt sich die spezielle Faktorenkombination insbesondere auf die randständigen Bäume aus. Strahlungsund Niederschlagsverteilung können sich hier als Stressfaktoren herausstellen, sei es um so den Weg für weitere Anfälligkeit durch Schadorganismen zu bereiten oder die physikalischen Standortsbedingungen negativ zu beeinflussen. Denn sowohl der Energieinput aus der Globalstrahlung als auch die Niederschlagsverteilung zeigen steile Gradienten am Bestandsrand mit deutlichen Unterschieden je nach Exposition. Der Einfluss des Strahlungsinputs wirkt sich auch deutlich auf den Wasserhaushalt aus, dies konnte durch den Vergleich von Modellberechnungen mit den „klassischen“ Bestandsinputwerten und modifizierten Werten für zwei Ränder gezeigt werden. Während für die randständigen Bäume eine Erhöhung des Trockenstresspotentials gegenüber dem Bestand festgestellt werden konnte, zeigte sich für den Jungwuchs auf der Kahlfläche an den länger beschatteten Bereichen ein erhöhter Wassersättigungsstress seitens des Bodens. Räumliche Muster dieser Art können zum einen durch die Form der Kahlfläche inmitten des Bestandes beeinflusst werden, zum anderen sollten solche räumlichen Muster erkannt werden und bei einer Aufforstung durch geeignete Baumarten genutzt werden. 
Ein besonderes Problem wurde im Randbereich des Kahlschlags auf diesen Stauwasser beeinflussten Böden aufgezeigt. Durch das laterale Eindringen von Stauwasser in den Altbestand kann es zu einer Minderung der Standfestigkeit der Bäume kommen. Dies macht sie anfällig gegen Sturmwurf.

Kahlschläge wirken sich ferner im Zusammenspiel mit extremen Witterungsphänomenen auf das hydrologische Geschehen aus. In den ersten Jahren ist die Humusauflage der Freifläche verhältnismäßig ungeschützt gegenüber den Witterungseinflüssen, so dass sie einer hohen zeitlichen Dynamik bezüglich ihrer physikalischen Eigenschaften unterliegt. Diese können sich mit dem Austrocknungsgrad ändern und eine erhöhte Hydrophobizität nach Trockenheit offenbaren, wodurch es zu oberflächeninduziertem Bypassfluss kommen kann. Gerade in den ersten Jahren, wenn der Stickstoffumsatz aufgrund des hohen Wasserangebots und des günstigen Mikroklimas erhöhte Raten aufweist, kann dies zu schubweisen Stoffverlagerungen führen.

Aus den Prozessbetrachtungen ist abzuleiten, dass in Einzugsgebieten, in denen das Grundwasser zur Trinkwassergewinnung dient oder deren Abfluss in Binnengewässer mündet, eine großflächige Durchführung von Kahlschlägen aufgrund der dadurch verstärkten Eutrophierungsgefahr nicht zu empfehlen ist. Betreffen die Stoffverlagerungen organische Komponenten, so dass leicht verfügbarer Kohlenstoff in tiefere Abschnitte gelangt, kann dies wiederum Rückwirkungen auf den Spurengashaushalt haben.

Alle diese Beispiele zeigen, dass Kleinkahlschläge bezüglich ihrer Funktionen nicht den Vorstellungen folgen, wie sie aus Untersuchungen großflächiger Kahlschläge oder nach Kahlhieben ganzer Einzugsgebiete abgeleitet wurden, so dass sie durchaus als alternative waldbauliche Maßnahme für eine nachhaltige Bewirtschaftung in Betracht kommen. Eine weitere Untersuchung auf anderen Standorten erscheint daher sinnvoll. 


\section{Zusammenfassung}

Der Umbau von Nadelholzreinbeständen in Laub- und Mischwälder stellt ein vorrangiges Ziel waldbaulicher Maßnahmen in Deutschland dar. Dadurch sollen stabile Bestandsstrukturen geschaffen werden, um Risiken durch Windwurf sowie Wasser- und Nährstoffstress aber auch Folgeschäden durch Schädlingsbefall zu begrenzen. So planen die Niedersächsischen Landesforsten in den nächsten vier Dekaden auf ca. 22 \% der Fläche (73.000 ha) die Überführung von Fichten- und Kiefernreinbeständen in Laub- und Mischwälder. In vorratsreichen Altbeständen, in windwurfgefährdeten Lagen oder bei der Überführung in Eichenbestände können neben der Zielstärkennutzung auch andere Hiebformen wie Femel- oder Saumhiebe bis hin zu kleinen Kahlschlägen waldbauliche Alternativen sein. Diese letztgenannten Hiebformen zeichnen sich dadurch aus, dass sie mehr oder weniger große Lücken in den Altbeständen hinterlassen, die sich hinsichtlich ihres Mikroklimas, ihrer Vegetation und damit verbunden hinsichtlich ihres Wasser- und Stoffhaushaltes deutlich von den sie umgebenden Beständen unterscheiden. Es treten laterale Gradienten auf, deren Ausprägung von der Größe und Form der Lücke, der Höhe der umgebenden Bäume sowie von der Himmelsrichtung und der Jahreszeit abhängig ist.

Im Focus der Untersuchungen zur raumzeitlichen Dynamik des Energie-, Wasserund Stoffhaushalts stand ein rechteckig angelegter Kahlschlag von ca. 2 ha Größe in einem 85-jährigen Fichtenreinbestand im Solling. Dieser wurde im Rahmen eines Fichtenhiebformenversuchs zusammen mit einer Zielstärke genutzten und einem unbehandelten Waldgebiet als Versuchsfläche angelegt. Die Flächen liegen auf $310 \mathrm{~m}$ über NN an einem schwach nach Nordwesten zum Wesertal geneigten Hang im mittleren Buntsandstein. Als Bodentyp wurde eine schwach podsolierte Parabraunerde mit niedrigen $\mathrm{pH}-$ Werten (3.5-4.4) ausgewiesen, die sich in einer Lößfließerde entwickelt hat.

Ziel dieser Arbeit war es, die räumliche Variabilität von ökologischen Kenngrößen zu ermitteln, welche durch den sprunghaften Übergang von der Freifläche in umstehenden $35 \mathrm{~m}$ hohen Bestand verursacht werden. Untersucht wurden

1. der Einfluss der Hiebform auf den Austausch der Spurengase Lachgas $\left(\mathrm{N}_{2} \mathrm{O}\right)$ und Methan $\left(\mathrm{CH}_{4}\right)$ in der initialen Phase

2. die räumliche Verteilung der Strahlung und Bodentemperaturen so wie deren Auswirkungen auf die $\mathrm{CO}_{2}$-Emissionen

3. der Wasserhaushalt unter Berücksichtigung der Randbereiche des Bestandes und des Kahlschlags sowie

4. die Bodenwasserdynamik nach extremen Witterungsereignissen.

Der erste Themenbereich beinhaltet die initialen Effekte der unterschiedlich starken Hiebmaßnahmen auf die Spurengasemissionen. Die Untersuchungen fanden im Jahr vor und nach dem Eingriff statt, als Bezug wurde der ungestörte Bestand 
herangezogen. Es wurde die Hypothese aufgestellt, dass im unbehandelten Bestand in stammnahen und stammfernen Bestandsbereichen Unterschiede im Spurengasaustausch durch unterschiedliche N-Depositionen, Niederschläge und Energieverteilung auftreten. Auf den Flächen mit Einzelbaumentnahme sollten sich diese Effekte verstärken. Auf der Kahlschlagfläche war eine weitere Steigerung zu erwarten, hier wurden Bereiche mit gestörten und ungestörten Humusauflagen so wie die Rückegassen berücksichtigt und verglichen.

Die Spurengasfreisetzung wurde mit geschlossenen Kammern gemessen, und statistisch ausgewertet. Die Flächenanteile der verglichenen Straten wurden erfasst und für eine Berechnung der Emission der Gesamtflächen verwendet. Es konnte festgestellt werden, dass eine Stratifizierung unter dem unbehandelten Altbestand nicht nachweisbar war. Bei der Zielstärkennutzung dagegen traten deutliche Veränderungen in Distanz zu den entnommenen Bäumen auf. Auf der Kahlschlagfläche trat eine deutliche Differenzierung zwischen der Rückegasse und den nicht befahrenen Flächen zutage. Die Rückegasse hatte einen sehr starken Einfluss auf die Gesamtemission des Kahlschlags. Obwohl ihr Flächenanteil nur $20 \%$ betrug, wurde die Gesamtemission um 30 \% erhöht. Für die kumulierten Lachgas $\left(\mathrm{N}_{2} \mathrm{O}\right)$ Emissionen der drei Varianten ergab sich eine Reihung vom unbehandelten Bestand $\left(23 \mathrm{mg} \mathrm{N} \mathrm{m}^{-2}\right.$ $\left.158 \mathrm{~d}^{-1}\right)$ über die Zielstärkennutzung (42 $\left.\mathrm{mg} \mathrm{N} \mathrm{m}^{-2} 158 \mathrm{~d}^{-1}\right)$ zum Kahlschlag (111 mg N $\left.\mathrm{m}^{-2} 158 \mathrm{~d}^{-1}\right)$. Dieses Ergebnis zeigt, dass bei einer wiederholten Zielstärkennutzung die akkumulierten $\mathrm{N}_{2} \mathrm{O}$-Austräge durchaus über denen des Kahlschlags liegen können.

Hinsichtlich der Methanoxidation in den Böden, wurde eine deutliche Verringerung nur auf der Kahlschlagfläche beobachtet, die verglichen zum Altbestand eine um $130 \mathrm{mg} \mathrm{CH}_{4}-\mathrm{C} \mathrm{m}^{-2} 158 \mathrm{~d}^{-1}$ reduzierte Aufnahme aufwies. Die stärkste Wirkung zeigte sich auf den Rückegassen, durch zeitweise Methanfreisetzung. Insgesamt blieb auch auf der Kahlschlagfläche die Funktion des Bodens als Methansenke erhalten. Kein Effekt auf die Methanaufnahme gegenüber dem unbehandelten Altbestand konnte nach Zielstärkennutzung festgestellt werden.

Der zweite Themenbereich widmet sich der raumzeitlichen Variabilität der Energieverteilung und der Temperaturen im Oberboden beiderseits der Baumkronenlinie in den Bestand und auf den Kahlschlag. In einer kreuzweisen Anordnung wurden in Transekten vom Inneren des Bestandes über den Bestandsrand auf die Freifläche die Temperaturen des Oberbodens gemessen. Entlang dieser Transekte wurde auch die Strahlungsverteilung durch eine Strahlungsmodellierung der Abteilung Bioklimatologie ermittelt. Eine empirische Funktion wurde hinsichtlich ihrer Anwendbarkeit auf die Beziehungen zwischen Strahlungsenergie und Bodentemperaturen über die Ränder des Kahlschlags hinweg überprüft. Dieses diente schließlich als Interpolationsschema, mit dessen Hilfe die Auswirkung unterschiedlicher Expositionen auf die Steilheit untersucht und die Ausdehnung der Bereiche in denen sich die Temperaturen sowohl vom Kahlschlagzentrum als auch vom Inneren des 
Altbestandes unterscheiden, dargestellt werden konnten. Aus der Betrachtung der so gewonnenen flächenhaften Bodentemperaturen - gemittelt über mehrere Jahre - ließ sich ein Abbild des raumzeitlichen Musters ableiten, das unabhängig von den Witterungseinflüssen eines einzelnen Jahres ist. Für den Südostrand zum Beispiel wurde für den Juli ein Gradient ermittelt, der sich über eine Entfernung von $80 \mathrm{~m}$ erstreckte. Davon entfielen $23 \mathrm{~m}$ auf den Altbestand und $57 \mathrm{~m}$ auf die Freifläche. Im September verlängerte sich die Überganszone aufgrund des Sonnenstandes sogar auf $95 \mathrm{~m}$. $44 \mathrm{~m}$ entfielen auf den Altbestand und $51 \mathrm{~m}$ auf die Freifläche. Die flächenhafte Interpolation der Bodentemperaturen wurde mit einer Funktion der $\mathrm{CO}_{2}$-Freisetzung aus der Humusauflage in Abhängigkeit der Temperatur verschnitten. Dabei zeigten sich in den Übergangsbereichen deutliche Unterschiede in den Raten der $\mathrm{CO}_{2}$-Emissionen. Bei einer gemeinsamen Berücksichtigung der Übergangszonen der Expositionen konnte gezeigt werden, dass für allgemeine Abschätzungen der $\mathrm{CO}_{2}$-Emission mit einem vereinfachten Modell gearbeitet werden konnte, dass nur den Altbestand und die Freifläche berücksichtigte.

Der dritte Themenbereich behandelt räumliche Modifikationen des Bodenwasserhaushalts nach Kahlschlag. Die erhobenen zeitabhängigen bodenphysikalischen und meteorologischen Variablen dienten als Eingangsgrößen für die Modellierung des Wasserhaushaltes mit dem Modellsystem EXPERT-N. Ferner wurde auf die Erkenntnisse über den Abfall der Strahlung in den Randbereichen der Freifläche und des Bestandes wie unter Themenbereich zwei beschrieben zurückgegriffen. Hinzu kamen die an vier Standorten ermittelten hydraulischen Funktionen der jeweiligen Böden. Die betrachteten vier Standorte befanden sich (i) im umgebenden Altbestand, (ii) am nordwestlichen Rand des Altbestandes (Peripherie 1), (iii) im Zentrum des Kahlschlags und (iiii) am südwestlichen Rand des Kahlschlags (Peripherie 2). Die standortsspezifischen Faktorenkombinationen aus Strahlungsinput, Niederschlag, Interzeption und Transpiration führen zu Stresssituationen an den peripheren Standorten bezüglich des Bodenwasserhaushalts. Für den an den Kahlschlag nordwestlich angrenzenden Altbestand (Peripherie 1) wurde eine Erhöhung der Tage an denen Fichten Anzeichen von Trockenstress aufweisen (+26 Tage) im Vergleich zum Innenbereich des Fichtenbestandes beobachtet. Am Südwestrand des Kahlschlags (Peripherie 2) dagegen wurden gegenüber dem Kahlschlagzentrum höhere $(>-10 \mathrm{hPa})$ Bodenwassergehalte beobachtet, die auch häufiger auftraten (+122 Tage) bzw. längere Intervalle umfassten. Diese können sich negativ auf das Wurzelwachstum der Jungpflanzen auswirken.

Der vierte Teil behandelt Aspekte der Bodenwasserdynamik unter besonderen hydrologischen Bedingungen. Es wurde das hydrologische Geschehen im Boden nach einer rapiden Schneeschmelze und nach heftigen Sommergewittern, die einer Trockenperiode folgten, beobachtet und interpretiert. Vor den Messungen im Feld wurde ein Sensortyp $\left(\mathrm{ECH}_{2} \mathrm{O}\right)$, der zur Registrierung des Bodenwassergehalts im Feld 
eingesetzt werden sollte, im Labor kalibriert. Dabei wurde der Einfluss des Abstands zwischen Sensor und umgebender Matrix, wie er durch Quellung und Schrumpfung im Boden auftreten kann, untersucht.

Der Vergleich der beobachteten Wassergehalte und der Matrixpotentiale in verschiedenen Tiefen (20 und $60 \mathrm{~cm}$ ) verdeutlichte das zum Bestandsinneren unterschiedliche Verhalten des Bodenwassers auf der Kahlschlagfläche. Während im Boden des Altbestandes die Sättigung der Bodenmatrix während beider Ereignisse gemäß den im Boden auftretenden Gradienten folgte und frontal verlief, konnten im Boden des Kahlschlags nach den heftigen Regenfällen Anstiege der Bodenwassergehalte in tieferen Schichten festgestellt werden, obwohl die Gradienten der hydraulischen Potentiale aufwärts gerichtet waren. Ein vergleichbares Verhalten konnte auch nach der Schneeschmelze festgestellt werden. Dies bedeutet, dass auf der Kahlschlagfläche bei extremen Infiltrationsraten ein erheblicher Anteil des Wassers in Makroporen abgeführt wird. In den Wintermonaten gefriert der Oberboden auf der Freifläche zu einem früheren Zeitpunkt als im Altbestand, wodurch eine weitgehend undurchlässige Oberfläche geschaffen wird. Schmelzwasser kann jedoch in Makroporen eindringen, welche nicht durch Eis versiegelt sind und an der Matrix vorbei abgeführt werden. Die Humusauflage des Kahlschlags ist in den ersten Jahren im Sommer relativ ungeschützt dem atmosphärischen Einfluss ausgesetzt, was zu einer starken Austrocknung führen kann. Dies führt unter anderem zu einer Verminderung der Benetzbarkeit der organischen Auflage, mit der Folge, dass ein erhöhter Anteil des Niederschlagswassers den Weg über Bypässe in den Boden nehmen kann, zumal durch den Eingriff Bereiche mit gestörter Humusauflage geschaffen wurden. Mit diesem schnell verlagerten Wasser, das ohne die Filterwirkung der Matrix in den Boden gelangt, können auch gelöste Stoffe und Partikel in die tieferen Bodenschichten gelangen. Betrifft dies organische Komponenten, können auf hydromorphen Böden Auswirkungen auf Spurengasemissionen auftreten.

Die Untersuchungen haben deutlich gemacht, dass eine Kahlschlagfläche in der Größe bis zu wenigen ha nicht als einheitlich bezüglich des Energie-, Wasser- und Stoffhaushaltes betrachtet werden darf. Die im Zentrum der Kahlfläche ermittelten Resultate lassen sich nicht ohne weiteres auf die Randpartien zu den benachbarten Altbeständen übertragen, da diese sich in ihren ökophysiologischen Eigenschaften zum Teil deutlich von denen der Kernfläche unterscheiden. Die randlichen Gradienten reichen teilweise mit in die Freifläche hinein und sind auch im Altbestand wirksam. Dies ist bei der Bewertung kleiner Kahlschläge aus ökologischer Sicht unbedingt zu berücksichtigen.

Die Ergebnisse haben auch gezeigt, dass Vorstellungen über die Wirkung von Kleinkahlschlägen einer genaueren Überprüfung unterzogen werden müssen. Dies gilt 
insbesondere der Frage der Stoffumsetzungen und dem damit verbundenem Austausch von Spurengasen.

\subsection{Summary}

The conversion of coniferous monocultures into deciduous and mixed forest is a priority aim of silvicultural efforts in Germany. The goal is to create robust forests which are resilient with respect to the risks of wind throw, water and nutrition stress and pest damage. For example the federal forest management of Lower Saxony plans the conversion of $22 \%$ of the forested area (73000 ha) from spruce and pine monocultures into deciduous and mixed forest within the next four decades.

Harvesting methods like partial harvesting, marginal strip cuts and clear cuts are silvicultural alternatives to single tree harvesting in forests, which are rich in wood, endangered by wind throw or planned to be converted to oak stand. Clear cutting creates gaps of different size within the mature forest. These gaps are distinctly different to the surrounding stand with respect to the microclimate, vegetation and especially with respect to their water- and nutrient balance. At the transition to the surrounding forest horizontal gradients appear whose characteristics depend on the size and the form of the gap, the height of the surrounding trees, the aspect and the season.

Our investigations, which focus on the spatiotemporal dynamics of energy, water and balance of matter, are conducted within a rectangular clear cut of about 2 ha in size within an 85 year old spruce monoculture in Solling (Germany). The clear cut was part of a program to investigate several methods of harvesting in spruce monocultures and was arranged together with a single tree harvesting area and a control plot of unchanged mature spruce stand at the same forest site. The area is located $310 \mathrm{~m}$ above sea level with a mild northeast slope. The soil type is a Dystric Cambisol with low $\mathrm{pH}$ values (3.5-4.4) derived from Triassic sandstone covered by loess.

The aim of this study was to investigate the spatiotemporal variability of ecological parameters, which are induced by the sudden transition from the clearing to the surrounding $35 \mathrm{~m}$ high forest stand. Investigated were:

1. the initial effect of harvesting on the trace gas emissions of nitrous oxide $\left(\mathrm{N}_{2} \mathrm{O}\right)$ and methane $\left(\mathrm{CH}_{4}\right)$

2. the spatiotemporal distribution of energy and soil temperatures and their effect on $\mathrm{CO}_{2}$ emissions

3. the water balance considering the edges of clear cut and forest and

4. soil water dynamics during extreme hydrological events.

In the first part the initial effects of different intensities of harvesting on trace gas emissions were analysed. Measurements were conduced in the year before and after harvesting. The unchanged mature forest stand served as reference plot. For the unchanged forest one of the hypotheses was that nearby trunk and between trunk 
locations differs with respect to the trace gas emissions due to differences in $\mathrm{N}$-deposition, throughfall and energy distribution. At the single tree harvesting plot effects were expected to be quite pronounced. A further increase was expected in the clear cut plot where locations with disturbed, undisturbed humus layer and skidding trails were studied.

Trace gas emissions were measured with the closed chamber method and statistically evaluated. The spatial allotments of the strata were considered for each plot and applied into the calculation of the plot emission. Stratification within the unchanged mature spruce stand was not observed. Distinct changes were however observed in distance to the harvested trees after the single tree harvesting. At the clear cut site strong differences between the skidding trails and the non-frequented area were found. The effect of the skidding trails on the whole plot emission was substantial. Although their spatial allotment amounted only to $20 \%$, the plot emission increased by $30 \%$, when considering the skidding trails. For the three treatments a sequence with increasing nitrous oxide emissions was found from unchanged mature forest (23 mg N $\mathrm{N}_{2} \mathrm{O}-\mathrm{N} \mathrm{m}^{-2} 158 \mathrm{~d}^{-1}$ ) over single tree harvesting (42 $\mathrm{mg} \mathrm{N}_{2} \mathrm{O}-\mathrm{N} \mathrm{m}^{-2}$ $\left.158 \mathrm{~d}^{-1}\right)$ to clear cut $\left(111 \mathrm{mg} \mathrm{N}_{2} \mathrm{O}-\mathrm{N} \mathrm{m}^{-2} \mathrm{~d}^{-1}\right)$. These results demonstrate that the $\mathrm{N}_{2} \mathrm{O}$ emissions in the single tree harvested plots may exceed the emissions from clear cuts, when the emissions are cumulated over repeated target diameter harvests.

In the second part the spatiotemporal variability of energy distribution and temperatures of topsoil on both sites of the tree base line into the forest stand and onto the clear cut area were investigated. Temperatures of topsoil were measured with a crosswise arrangement of transects from forest interior over the forest edge to the clearing. The energy distribution was derived from three dimensional irradiance modelling from the Department of Bioclimatology and was considered along the same transects. An empirical function was examined for its applicability on the relations between irradiance and soil temperature across the edges of the clear cut. The function was then used as an interpolation scheme to explore the effects of aspect on the slopes of gradients and the lateral extension of the area with temperatures in topsoil, which are different from clear cut centre as well as from forest interior. In this way spatiotemporal pattern of soil temperatures were generated, with average temperatures over some years, to gain a picture independent on singular weather conditions. At the southeast edge a gradient of a lateral extension of $80 \mathrm{~m}$ was found for May. $23 \mathrm{~m}$ lay within the surrounding stand and $57 \mathrm{~m}$ extended into the clear cut area. In September this transition zone even extended to $95 \mathrm{~m}$ due to the solar angle. Whereby $44 \mathrm{~m}$ of the transition zone was in the forest stand and $51 \mathrm{~m}$ was part of the clear cut. The spatial interpolated topsoil temperatures were used to calculate heterotrophic $\mathrm{CO}_{2}$ emissions from the forest floor with a temperature dependent function. Within the transition zones considerable changes in $\mathrm{CO}_{2}$ emission rates were found. However, if the transition zones of the different aspects were considered, it 
indicated that a simple model, which included only the situation in the clear cut centre and the forest interior, was sufficient for general calculations of $\mathrm{CO}_{2}$ emissions.

The third topic focused on the spatial modifications of soil water balance after clear cutting. Time dependent soil physical and meteorological variables were measured and served as input quantities for the modelling the water balance with the modular system EXPERT-N. Also the findings about the gradients of solar energy and the hydraulic functions at the four locations were incorporated. The four locations considered were (i) within the mature forest stand, (ii) at the northwest side of the clear cut but still within the stand (periphery 1), (iii) at the clear cut centre and, (iiii) at the southwest edge of the clear cut (periphery 2). A specific combination of factors of energy input, precipitation, interception and transpiration at each location led to stress at the peripheries of the forest margin. For example an increase in the number of days with water deficiency stress $(+26)$ was found for the forest stand at the northwest edge of the clear cut (periphery 1) compared to the forest interior. At the southwest edge of the clear cut an increase in days with soil water potential $(>-10 \mathrm{hPa})$ and with high water content (+122 days) was detected. The intervals of saturated conditions also increased. Such conditions may impede the root growth of seedlings.

In the fourth part the aspects of soil water dynamics after special hydrological events were examined. Soil hydrological parameters were registered after a rapid snow melt and after a summer storm preceded by a severe drought spell and discussed with respect to the processes involved. Prior to installing the probes for measuring the soil water content $\left(\mathrm{ECH}_{2} \mathrm{O}\right)$, the probes were calibrated in the lab. During the laboratory tests the effect of distance between sensor and matrix was tested. The possibility of swelling and shrinking of the soil and complications during insertion were shown as possible causes for the uncertainty of measurements.

The comparison of registered water contents and matric potentials in 20 and $60 \mathrm{~cm}$ depth demonstrates the different behaviour of soil water in the clear cut site in contrast to the forest interior. In the forest interior the saturation of the soil matrix followed the gradients and went in a horizontal front from top to bottom during both events. At the clear cut site an increase of soil water content in deeper soil layers was observed against upward hydraulic gradients after the summer storm. A similar pattern was observed during the rapid snow melt. Also a considerable part of water bypasses the matrix at high infiltrations rates in the clear cut. During winter months the topsoil in the clear cut freezes earlier than within the forest and leads to an extensive sealed surface. However, melt water reaches macropores not sealed by ice and gets into the soil without contact to the matrix. During the summer the humus layer in the clear cut is bare and directly exposed to the atmospheric impacts, what can lead to a strong drying. Among others, drying reduces the wettability of the humus layer and increases the bypass flow. Water bypassing the matrix may enhance the leaching of solutions 
and particles. If organic matter is involved, there may be affects on the trace gas emissions in hydromorphic soils.

These investigations demonstrate that it is not allowed to consider a small clear cut area up to few ha in size as a homogenous plot with respect to energy, water and matter balance. Results, which were gained in the centre of a small clear cut or within the forest, are not representative for the peripheral locations of the clear cut or the edge related forest stand, because in part they are quite different to the core areas. The gradients cross edges extend to the clearing and also affect the surrounding forest stand. This has to be regarded by the evaluation of small clear cuts from an ecological point of view. The results also show that the assessment of the impacts of small clear cuts have to be revised. This is especially valid for questions concerning matter turnover and the exchange of trace gases. 


\section{Danksagung}

Ich möchte mich bei allen bedanken, die zum Gelingen dieser Arbeit beigetragen haben, ohne vielleicht jeden einzelnen namentlich aufgeführt zu haben.

Allen voran möchte ich mich bei Herrn Prof. Dr. F. Beese bedanken, der mir das Thema zur Bearbeitung überlassen hat, aber auch dafür, dass ich noch viel von inm lernen konnte und für die Freiheiten, die er mir während der Zeit unserer Zusammenarbeit gewährte.

Auch möchte ich mich beim Labor der Abteilung Ökopedologie (ehemals Institut für Bodenkunde und Waldernährung) bedanken, stellvertretend seien hier Frau A. Kriegel und Herr N. Loftfield erwähnt.

Ferner haben bei Feldarbeiten des Öfteren verschiedene Personen mitgewirkt, für die Unterstützung bei Wind und Wetter geht mein herzlicher Dank an die Herren H. Mühlhan, M. Brünjes, G. Malinowski und D. Böttger.

Bei Herrn Dr. R. Brumme bedanke ich mich für Diskussion und Anregungen.

Für die gute Zusammenarbeit möchte ich mich natürlich bei den Kollegen und Kolleginnen der Abteilungen für Ökopedologie, der Abteilung für Ökoklimatologie und der Nordwestdeutschen Forstlichen Versuchsanstalt bedanken, insbesondere bei den Herrn U. Klinck, Dr. K. Radler und Frau G. Kutscher.

Ein ganz besonderer Dank gilt schließlich denjenigen, deren Beitrag eher moralischer Natur war, nämlich meiner Familie und meinen Freunden. Ganz besonders erwähnen möchte ich meine Eltern, die mir das Studium ermöglichten und meine Freundin Daniela für ihre außerordentliche Unterstützung. 
